\title{
[Symposium III]
}

\section{A 54 (Symp. III)}

RECENT DEVELOPMENT IN THE FIELD OF MOLECULAR CPTOGENETICS. NoriO NIIKAFA (Chairman) (Nagasaki University School of Medicine, Nagasaki)

Although previous cytogenetics and molecular genetics were both based on the common genetic laws, they did not actually and closely communicate each other. This might be due to the presence of a hurdle of dimensional difference between the subject studied. The use of recently developed molecular cytogenetics techniques has made a direct connection possible, as shown in figure. Fluorescence in situ hybridization is such a useful technique.

Another development includes the establishments of a number of segmental aneusomy syndromes, recognizable clinical entities with microdeletion or duplication. These abnormalities are detected in the chromosome and/or molecular level. The most successful example in the field of molecular cytogenetics is positional gene cloning, one of reverse genetics techniques. This has contributed to encourage many clinical geneticists, especially cytogeneticists. In this symposium, 3 molecular cytogene-

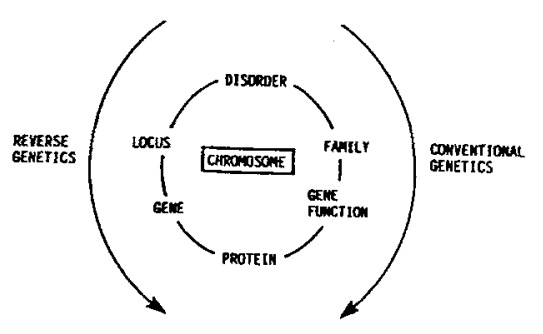
ticists present their recent study data focusing on each topic.

\section{A 55 (Symp. III)}

FLUORESCENECE IN SITU HYBRIDIZATION (FISH): APPLICATIONS IN GENE MAPPING, GENOME MAPPING AND CYTOGENETICS. Ei-ichi TAKAHASHI (Div. Genet., Natl. Inst. Radiol. Sci., Chiba)

Techniques of fluorescence in situ hybridization (FISH) have made it possible to localize DNA sequences on metaphase chromosomes and interphase nuclei. The current FISH techniques have, however, had some problems to be solved; 1) direct mapping on banded chromosomes, 2) detection of signals of small single copy genes $(<5 \mathrm{~kb})$, and 3$)$ elimination of repetitive sequences in genomic clones. The systems we have developed and modified are as follows; 1) direct mapping on replicated prometaphase R-bands, 2) amplification of signals by goat anti-biotin antibody and FITC antigoat IgG, and 3) elimination by in situ suppression hybridization with total human DNA. These systems facilitate a more rapid and efficient method not only for gene mapping, but also for genome mapping in constitution of cytogenetic maps with chromosome-specific cosmid libraries. Chromosome painting by FISH can be applied for the analysis of chromosome abnormalities. 


\section{A 56 (Symp. III)}

MICRODELETION SYNDROME AND DNA ANALYSIS. Yoshimitsu FUKUSHIMA (Division of Medical Genetics, Saitama Children's Medical Center)

The process of cloning a gene is compared to that of looking for one criminal on the earth. Linkage analysis is a time, labor and money consuming method. If we discover an unusual patient affected with both a genetic disorder and a constitutional chromosome aberration (microdeletion or balanced rearrangements), we can suspect the gene locus at the region or the breakpoint of the chromosomal aberration. Then, we might clone the gene easily by positional cloning strategy.

In this symposium, I displayed several patients with the following disorders and their contribution to molecular research of the disorder: Miller-Dieker syndrome (17p13), Alagille syndrome (20p11), piebalt trait (4q12), Smith-Magenis syndrome(17p11), Aicardi syndrome (Xp22.3), familial aniridia (11p13), Waardenburg syndrome(2q35), ectrodactyly, ectodermal dysplasia and clefting syndrome (7q11 or 9p12), Rubinstein-Taybi syndrome (2p13) and blepharophimosis sequence (3q23).

Clinical genetics and cytogenetics play an important part in progress of Human Genetics, as well as molecular genetics. We have the advantage of easiness for chromosome analysis in medical examination. Many other important discoveries will be done in our country.

\section{A 57 (Symp. III)}

APC (Adenomatous Polyposis Coli) gene and colorectal tumor Yusuke NAKAMURA, (Dept. Biochem. Cancer Inst., Tokyo)

Familial polyposis coli (FAP) is an autosomal dominant hereditary disease characterized with hundred to thousand of adenomatous polyps in colon, some of which develop to colon carcinomas, if left without surgical treatment. We have isolated the APC (Adenomatous Polyposis Coli) gene responsible for $F A P$ by the positional cloning metohd and identified germ-line mutations of the APC gene in more than 60 FAP patients. Most of them were disrupted the gene product due to point mutation, or frame shift mutation by 1-5 base-pair insertion or deletion. Amino acid changes due to a single base mutation were observed in only several cases. Mutations are scattered throughout the gene, which codes 2843 amino acids, and no hot spot of mutation was identified. In addition to germ-line mutations, we also found somatic mutations of the APC gene in several cases of sporadic colon cancer. 


\section{A 58}

QUANTITATION OF GENE EXPRESSION BY RT-PCR. Teruaki NAKANO, Takeshi OTSUKA, Tomonor i OGO, Hi ronobu SATOH, Hi roaki NIIRO, Yuko FURUKAWA and Yoshiyuki NIHO (The 1st Dept. Int. Med. Kyushu Univ., Fukuoka, Japan)

RT-PCR (Reverse transcription-polymerase chain reaction) is useful to detect less frequent RNA in the sample. Therefore, this method seems to be useful to determine the gene expression in the sample of limited amount, especially to evaluate clinical samples. In the present study, we report the method of quantitation of c-kit ligand mRNA. c-kit ligand cDNA was inserted a $161 \mathrm{bp}$ DNA fragment (pCKLD1). Molecules of PCR product derived from PCKLD1 as a template increase at the same speed as those derived from $c-k i t$ ligand cDNA. When we evaluate the expression levels of c-kit ligand gene in three different mouse stromal cell lines, both fibroblast and fibroendothelial cell lines express this mRNA $(100 \sim 200 \mathrm{fg} / \mu \mathrm{g}$ of total RNA). On the other hand, the endothelial-adipocyte cell line which has a unique feature to support long term hemopoiesis in vitro expresses undetectable level. Thus, this method is useful to compare the gene expression quantitatively. This method was also useful to evaluate the expression of other cytokine genes( IL-2, IL-4 and IFN- $\gamma$ ).

\section{A 59}

MORQUIO DISEASE: ISOLATION, CHARACTERIZATION AND EXPRESSION OF FULL LENGTH CDNA FOR HUMAN N-ACETYLGALACTOSAMINE-6-SULFATE SULFATASE Se iji FUKUDA, Shun ji TOMATSU, Michiya MASUE, Kazuko SUKEGAWA, Hidek i IWATA, Tatsuya OGAWA, Yoshihiro NAKASHIMA, Toshinori HORI, Atsushi YAMAGISHI, Yuko HANYU, Toshiya SASAKI and Tadao ORII (Dept. Pediatrics, Gifu Univ. School of Medicine. ,Gifu)

$\mathrm{N}$-acetylgalactosamine-6-sulfate sulfatase (GalNAc6S sulfatase) is required for lysosomal degradation of keratan sulfate and chondroitin-6-sulfate. Mutations causing GalNAc6S sulfatase deficiency result in Morquio disease. We have cloned and sequenced a 2. 3Kb cDNA coding for the entire sequence of human placental GalNAc6S sulfatase. The deduced amino acid sequence comprises 522 amino acids with an N-terminal signal peptide of 26 residues, including two potential $\mathrm{N}-$ glycosylation sites. Expression of the cDNA in transfected deficient fibroblasts resulted in higher GalNAc6S sulfatase activity than in untransfected cells. The Ga1NAc6S sulfatase cDNA hybridized to only 2 . 3Kb-RNA species from human fibroblasts. The amino acid sequence of the GalNAc6S sulfatase has a high degree of homology with other sulfatases, indicating that the sufatases arose from a common ancestral gene and belong to one gene family. 
A 60

POLYMORPHISM OF PLASMINOGEN WITH TYPE I MUTATION IN JAPANESE AND CHINESE HAN POPULATIONS. Liming LI, Shu-ichi KIKUCHI, Yasuko YAMANOUCHI, Hideo HAMAGUCHI (Dept. Med. Genet. Univ. Tsukuba) and Shigeru TSUCHIYA (Inst. Comm. Med. Univ. Tsukuba)

A functionally inactive plasminogen(PLG) variant designated PLG M5 is polymorphic in the Japanese population but the frequencies have not beenreported in Chinese populations. This study was done to reveal the PLG M5 allele frequencies in Chinese Han population and to clarify whether the gene for PLG M5 is identical with the PLG gene with type I mutation that has a codon 601 missense mutation in exon 15 (GCT for Ala $\rightarrow$ ACT for Thr). As the result of isoelectric focusing followed by immunoblotting, three heterozygotes for PLG M5 were detected in 104 unrelated healthy Chinese(Han) living in Japan(2.9\%), and eight heterozygotes for PLG M5 were observed in 360 unrelated healthy Japanes(2.2\%). All 11 heterozygotes for PLG M5 had decreased PLG activities but normal PLG antigen concentrations. The allele freqencies for PLG*M5 in Chinese Han and Japanese populations were 0.014 and 0.011 , respectively. Direct sequencing of the amplified DNA from the PLG gene in a heterozygote for PLG M5revealed that the sequence of the exon 15 in the gene for PLG M5 is identical with that in the PLG gene with type I mutation. In addition, the amplified DNA from the PLG gene in 11 heterozygotes for PLG M5 all reacted with the probe for type I mutation in dot-blot hybridization. These results indicate that the PLG M5 is identical with PLG with type Imutation and that the mutation is polymorphic in Japanese and Chinese Han populations.

\section{A 61}

Expression of neurotrophin-3(NT-3) gene in insect cells by a baculovirus vector. Masaharu ISOBE, Yoshinori KUMURA, Hideki NAGUMO, Nobuyuki KUROSAWA, Zen-ichi OGITA (Dept. Patho-biochem., Toyama Medical and Pharmaceutical Univ., Toyama)

Neurotrophic factors have been implicated in the proliferation and differentiation of neurons during embryonic development and in their growth and survival in the adult nervous system. Recently the gene for the third neurotrophic factor, $\mathrm{NT}^{\mathrm{T}}-3$ has been cloned by means of sequence conservation between nerve growth factor(NGF) and brain derived neurotrophic factor(BDNF). Since NT-3 was identified from the gene, physiological significance of NT-3 protein is still unknown. As a first step to understand the effect of NT-3, we have established the method for production of NT-3 using a baculovirus vector.

A plasmid pAc373NT-3 was constructed and co-transfected into Spodoptera frugiperda(Sf9) cells with wild-type Autographa californica nuclear polyhedrosis virus(AcNPV) DNA. The recombinant virus vAc373NT-3 was identified and purified by several rounds of plaque hybridization. By assaying the culture medium, we demonstrated recombinant virus infected Sf9 cells expressing NT-3. 


\section{A 62}

MOLECULAR GENETIC ANALYSIS OF THE RED-GREEN VISUAL PIGMENT GENE REGION IN JAPANESE ADRENOLEUKODYSTROPHY PATIENTS.

Ryoko KOIKE, Shiji TSUJl (Dept. Neurol., Ni igata Univ., Ni igata), Robert FEIL (Lab. Genet., INSERM IJ,, Strasbourg, France), Toshiko NAGASHIMA, Tetsuo KOMORI (Tokyo Metrop. Neurol. Hosp., TOkyo), Yuuj i YOKOYAMA, Kouji NARAHARA (Dept. Periatr., Okayama Univ., Okayama) and Tadash i MIYATAKE (Dept. Neurol., Tokyo Med. Dent. Univ., Tokyo)

The red-green visual pigment gene loci of 27 Japanese ALD kindreds have been analyzed by Southern blot hybridization using hs7 as a probe. Two patients from different families showed deletion of all green pigment genes. The flanking regions of the red-green visual pigment genes were also analyzed using 6 genomic probes that lie $3^{\prime}$ or $5^{\prime}$ of the visual pigment gene. No deletions were found with these probes and the deletions of green pigment gene were not extended to downstream from the end of the green pigment gene, as no abnormalities were revealed with a genomic probe $30 \mathrm{~kb}$ downstream of the green pigment genes. As one ALD patient was reported to have large deletion involving upstream of the red pigment gene, AlD gene has been suggested to locate upstream of the red pigment gene. Detailed analysis of this region in a large number of ALD patients will be required.

\section{A 63}

ISOLATION OF 400 NOtI LINKING CLONES CONTAINING CPG ISLANDS

AT Xq24-Xq28 LOCUS.
Kiyotoshi KANEKO $^{1}$, Stephen T. WARREN Tadashi MIYATAKE 3 , and Shoji TSUJI ( ${ }^{1}$ Dept. Neurol., Niigata Univ., Nijigata; ${ }^{2}$ Dept. Biochem. and Pediat., Emory Univ., Atlanta; ${ }^{3}$ Dept. Neurol., Tokyo Med. Dent. Univ, Tokyo)

A cosmid library was constructed from a human-hamster somatic cell hybrid (X3000-11.1), which contains Xq24-qter as an only human chromosome. Screening the library with radiolabeled total human genomic DNA identified 1,784 cosmid clones. Four hundred of the cosmids were identified as NotI linking clones. We have identified 11 clusters at Xq24-25, 6 clusters at Xq26-27, and 19 clusters at Xq28. Seventy four clones contained multiple SacII sites within a $2 \mathrm{~kb}$ region as well as 1 to 6 sites for BssHII, MluI, or NruI. Nine (75\%) of 12 randomly picked clones detected unmethylated HpaII sites. Our method is highly efficient for isolating linking clones for any rare cutter sites associated with potential CPG islands. Such cosmids are useful for long range physical mapping. We have also identified a transcript using a cosmid clone containing potential CPG islands as the probe, which suggests that our method is also useful for identifying transcripts. 


\section{A 64}

CORRELATION OF POPULATIONS OF MUTANT MITOCHONRIAL DNA WITH THE SEVERITY OF MYOCLONUS EPILEPSY ASSOCIATED WITH RAGGED-RED FIBERS (MERRF).

Yoshinori TANNo, Makoto YONEDA, Keiko TANAKA, Shoji TSUJI, (Dept. Neurol., Ni igata Univ., Ni igata), Tadashi Miyatake (Dept. Neurol., Tokyo Med. Dent. Univ., Tokyo) and Ikuya NONAKA (Div. U1trastruct. Res., Nat. Cent. Neurol. Psychiat., Tokyo)

MERRF is a maternally inherited encephalomyopathy characterized by myoclonus, epilepsy, cerebellar ataxia, dementia and myopathy. Recentry, a point mutation in tRNA ${ }^{\text {Ly a }}$ gene of the mitochondrial DNA (mtDNA) has been identified as a primary genetic defect causing MERRF. Furthermore presence of both the wild type and the mutant mtDNAs (heteroplasmy) has been shown to occur in MERRF. To see if there is a correlation between the degree of heteroplasmy and the severity of MERRF, we have quantitated the ratios of the mutant mtDNAs in 5 MERRF patiens by devising a novel method for quantitation. Though there is a tendency that patiens with less wild type mtDNAs show severe clinical symptoms and earlier onset, the tight linkage of the severity of symptoms and the degree of heteroplasmies is not necessarily observed for all cases.

\section{A 65}

GENETIC ANALYSIS OF FAMILIAL HYPERTROPHIC CARDIOMYOPATHY: A STUDY ON CARDIAC MYOSIN HEAVY CHAIN GENES

Haruhito HARADA $^{1,2}$, Akinori KIMURA $^{2}$, Hirofumi NISHI ${ }^{1,2}$, Yoshinori KOGA ${ }^{1}$, Hironori TOSHIMA $^{1}$ and Takehiko SASAZUKI ${ }^{2}$ ( ${ }^{1}$ Third Dept. Int. Med., Kurume $^{2}$ Univ., Kurume, ${ }^{2}$ Dept. Genet., Med. Inst. Bioreg., Kyushu Univ., Fukuoka)

Although missense mutation and $\alpha / \beta$ hybrid gene of cardiac myosin heavy chain (MHC) gene have been reported in caucasian families with hypertrophic cardiomyopathy (HCM), it is still unknown whether these abnormalities are found in other patients with HCM. In order to determine whether reported mutations occur in Japanese HCM, we analysed the MHC gene from 101 unrelated Japanese patients with HCM. A DNA region spanning the exon 13 to $15(870 \mathrm{bp})$ of cardiac $\beta$ MHC gene was amplified from 101 patients and 8 normal individuals by PCR (polymerase chain reaction) method. Since the reported missense mutation from $G$ to $A$ in the exon 13 should generate a new Ddel site (CTNAG), the PCR products were digested with DdeI and analysed them in a polyacrylamide gel electrophoresis. Southern blot analyses was also performed using probes corresponding to the exon 13-15 and 27-28 respectivery, because the reported hybrid gene is expected to generate an unusual DNA fragment. Nevertheless no Japanese patients with HCM showed any evidence for the reported mutations of cardiac MHC gene.

On the other hand, our linkage study strongly suggested a major gene for Japanese HCM is linked to PALB. 
A 66

CLONING AND STRUCTURAL ANALYSIS OF HUMAN PIT-1 GENE, AND GENOMIC ANALYSIS OF PATIENTS WITH CONBINED DEFICIENCY OF GH, PRL AND TSH
Kouji OHTA, 1 Yoshitaka NOBUKUNI, Hjroshi MITSUBUCHI, Fumio ENDO, Shigehiro FUJIMOTO, Ichiro MATSUDA ('Dept. Pediatr. Kumamoto; Dept. Pediatr., Miyakonojyo National Hospital, Miyazaki)

Congenital human growth hormone (hGH) deficiency is classified into two types; isolated hGH deficiency and multiple pituitary hormone deficiencies. There are three dwarf mouse strains with defective secretion of $\mathrm{GH}, \mathrm{PRL}$ and $\mathrm{TSH}$, in which one has a gross structural alteration of the pit-1 gene and the other has a missense mutation in it. Pit-1 is a pituitary-specific transcription factor and binds to cis-active elements in GH and PRL, and can transactivate both gene promoters. We experienced several patients with conbined deficiency of GH, PRL and TSH. Therefor, we have done the cloning and the structural analysis of the human PIT-1 gene. The human PIT-1 gene is at least $14 \mathrm{kbp}$ long and split into 6 exons. The splice donor and acceptor sites conform to the GT/AG rule. Human PTI-I shares extensive homology with rat pit-1 and mouse pit-1. Genomic DNA from two patients with conbined deficiency of $\mathrm{GH}$, PRL and TSH, gave the same restraction mapls on Southern blot.

\section{A 67}

MOLECULAR ANALYSIS OF PROLIDASE DEFICIENCY

Fumio ENDO, Akito TANOUE, Hisataka AWATA, and Ichiro MATSUDA (Dep. Pediatrics, Kumamoto University Medical School)

Human prolidase (imidodipeptidase, Peptidase D) and related deficiencies were analyzed in terms of the nature and molecular biology of the enzyme and the molecular events seen in patients with this deficiency. The studies revealed that human prolidase is a homo-dimer of an identical subunit with 492 amino acid residues. The gene (PEPD) was localized on chromosome 19, spanned more than $130 \mathrm{Kbp}$ and split into 15 exons. Molecular defects in prolidase deficiency were then analyzed. Two patients with the polypeptide-positive phenotype of the disease carried a gene deletion that encompassed exon 12. Two siblings with a polypeptide-negative phenotype carried a gene deletion that encompassed exon 14. These mutations were not found in ten other patients with the diseases, hence the molecular defects in prolidase deficiency are apparently highly heterogeneous. The mental retardation was apparently related to mRNA negative phenotype. 


\section{A 68}

GENE ANALYSIS OF MENNONITE MAPLE SYRUP URINE DISEASE KINDRED, USING PRIMER SPECIFIED RESTRICTION MAP MODIFICATION. Hiroshi MITSUBUCHI, Yoshitaka NOBUKUNI, Kouji OHTA, Yasuhiro INDO, Fumio ENDO and Ichiro MATSUDA (Dept. Pediatr., Kumamoto Univ., Kumamoto )

Maple syrup urine disease (MSUD) is an autosomal recessive inherited disease due to a deficiency of any of the subunits, $E_{2}, E_{1} \beta$ or $E_{2}$ of the branched-chain $\alpha$-keto acid dehydrogenase complex (BCKDH). A Iarge Mennonite kindred of MSUD has been studied in Pennsylvania, U.S.A. In the present investigation, genomes from eighty-four members, including fifteen patients belonging to ten different Mennonite MSUD pedigrees were examined for possible abnormalities in the $E_{1}$ o gene of $B C K D H$, by primer-specified restriction map modification. A $\mathrm{T}$-to-A substitution which generates an asparagine in place of a tyrosine at amino acid 394 of the mature $\mathrm{E}_{1} \alpha$ subunit was present in both allels in all the patients and in ${ }^{1}$ a single allele in all obligate carriers and several siblings. We described a new technique for rapid and easy detection of the mutant gene in this population. These family studies provide additional evidence that Mennonite MSUD is caused by a missense mutation of the $\mathrm{E}_{1} \alpha$ gene of $\mathrm{BCKOH}$.

\section{A 69}

STRUCTURAL ORGANIZATION OF THE GENE FOR THE E, $\beta$ SUBUNIT OF HUMAN BRANCHED CHAIN $\propto$-KETOACID DEHYDROGENASE AND THE GENE ANALYSIS OF THE MAPLE SYRUP URINE DISEASE PATIENTS

Yoshitaka NOBUKUNI, Hiroshi MTTSUBUCHI, Kouji OHTA, Yasuhiro INDO, Fumio ENDO and Ichiro MATSUDA (Dept. Pediatr., Kumamoto Univ., Kumamoto)

A deficiency of the branched chain $\alpha$-ketoacid dehydrogenase complex (BCKDH) results in maple syrup urine disease (MSUD). BCKDH comprises $\mathrm{E}_{1}$ (decarboxylase), $\mathrm{E}_{2}$ (transacylase) and $\mathrm{E}_{3}$ (dihydrolipoamide dehydrogenase). $E_{1}$ component is further composed of subunits $E_{1} \alpha$ and $E_{1} \beta$. Previously, we reported the defects of $E_{1} \beta$ in MSUD patients by immunoblot analysis. In order to elucidate the molecular mechanisms of the $B C K D H-E_{2} \beta$ defect, we characterized the structural organization of the gene for the human $\mathrm{BCKDH}-\mathrm{E}_{1} \beta$. The gene of $\mathrm{E}_{1} \beta$ is over $100 \mathrm{kbp}$ long and is split into 10 exons. ${ }^{\mathrm{All}}$ of the splice donor and acceptor sites conform to the GT/AG rule. We analyzed the MSUD patients with the $\mathrm{BCKDH}-\mathrm{E}_{1} \mathrm{~B}-\mathrm{CRM}$ defect, and elucidated that MSUD-Nara is a frameshift mutation due to a deletion of an 11-bp repeat sequence which encodes a mitochondrial targetting leader peptide of $\mathrm{E}_{1} \mathrm{~B}$. 


\begin{abstract}
A 70
MOLECULAR ANALYSIS OF TYPE 3 TYROSINEMIA-CLONING OF MAMMALIAN PARAHYDROXYPHENYLPYRUVATE DIOXYGENASE CDNAS

Hisataka AWATA, Fumio ENDO, Akito TANOUE, Ichiro MATSUDA (Dept. Pediatrics, Kumamoto University Medical School., Kumamoto) and Hideki KATOU (Laboratory of Genetics, Central Institute for Experimental Animals., Kanagawa)

Type 3 tyrosinemia, which is an autosomal recessive disease of amino acid metabolism, caused by the deficient activity of liver parahydroxyphenylpyruvate dioxygenase (HPD). We have cloned the human, mouse, and porcine HPD cDNAs. Each CDNA consists of 1.2-1.4 kb nucleotides. All cDNAs contain 1179 bp open reading frame. It was presumed that HPD was consisted of 393 amino acid residues and that calculated molecular weights of HPD were 44817-44950. These results were compatible with the data of amino acid analysis of portine HPD. Expression of HPD CDNA in vitro was investigated in BMT 10 cell. A molecular weight 43,000 protein that reacted with monoclonal antibody directed against HPD. HPD activity was detected from BMT 10 cell in which human HPD cDNA was expressed.
\end{abstract}

\title{
A 71
}

DNA ANALYSIS OF Y CHROMOSOME USING Y SPECIFIC DNA PROBES Takashi TAMURA $^{1,2}$, Shigeo NAGAFUCHI $^{1}$, Yutaka NAKAHORI $^{1}$, Hironao NUMABE ${ }^{1}$, Toshiyuki FURUSHO ${ }^{2}$ and Yasuo NAKAGOME ${ }^{1}$ ('Dept. Cong. Abn. Res., Natl. Child. Med. Res. Ctr., Tokyo, ${ }^{2}$ Dept. Clin. Genet., Kyorin Univ. School Hith. Sci., Tokyo)

We have examined DNA samples of patients with a marker chromosome and those with abnormalities of sexual development using Y-specific DNA probes. 16 probes detected 22 different loci and located on either the short arm or the proximal long arm of the Y chromosome. The probe $\mathrm{pHY} 10$ detects the repetitive DNA family DYZ1 in the Q-positive region of the Y chromosome. In addition, 2 sets of oligonucleotide primers were used to detect PABY or SRY locus near the distal end of the short arm. Consequently, a total of 25 sites along the $\mathrm{Y}$ chromosome can be detected.

Among the clinical samples of 228, a total of 69 patients with a structurally abnormal $Y$ chromosomes were detected. In 9 of patients with XX male, $Y$ chromosome material were present. Breakpoints were distributed over the entire length of the short arm of the Y chromosome, the shortest had only 2 loci, PABY or SRY, on the other hand a patient had almost intact Yp. 


\section{A 72}

PCR DETECTION OF STRUCTURALLY ABNORMAL Y CHROMOSOMES.

$\underline{\text { Hironao NUMABE }}^{1,2}$, Shigeo NAGAFUCHI $^{1}$, Satoko SEKI $^{1}$, Yutaka NAKAHORI ${ }^{1}$, Takashi TAMURA $^{1,3}$, Akinori HOSHIKA ${ }^{2}$ and Yasuo NAKAGOME ${ }^{1}$ ( Dept. Cong. Abn. Res., Natl. Child. Med. Res. Ctr., Tokyo, ${ }^{2}$ Dept. Pediatr., Tokyo Med. Coll., Tokyo, ${ }^{3}$ Dept. Clin. Genet., Kyorin Univ. Sch. Hlth. Sci., Tokyo)

Three novel sets of primers were developed by sequencing three known single-copy probes and used to detect three sites in the proximal long arm (DYS139, DYS132 and DYS1) of the human Y chromosome. Their loci were in intervals 5 to 6 of the $Y$ chromosome. Four sets of primers, three on the short arm (PABY, SRY, AMGL) and one on the long arm (DYZ1), were previously reported, and were used along with the novel three sets to detect sites distributed over the length of the $Y$ chromosome. By using these seven sets of PCR primers, we analyzed DNA samples of patients with structurally abnormal Y chromosomes. The results of PCR detection in eight samples of patients were consistent with those obtained by Southern analysis of the same samples using $Y$ chromosome probes. In patients of Turner syndrome with marker chromosomes or in sex reversed patients, it is often important to know the presence or absence of $Y$ chromosome material. PCR primers described here are thought to be very useful in the screening of patients with structurally abnormal $Y$ chromosomes.

\section{A 73}

DNA ANALYSIS OF THE Y CHROMOSOME IN MEN WITH AZOOSPERMIA. $\underline{\text { Shigeo NAGAFUCHI }}^{1}$, Yutaka NAKAHORI ${ }^{1}$, Takashi TAMURA ${ }^{1,2}$, Mikio NAMIKI $^{3}$, Hironao NUMABE $^{1,4}$ and Yasuo NAKAGOME ${ }^{1}$ (1 Dept. Cong. Abn. Res., Natl. Child. Med. Res. Ctr.., 2 Dept. Med. Genet., Kyorin Univ., 3 Dept. Urol., Univ.Osaka, 4 Dept. Pediat., Tokyo Med. Coll.)

Sixty-four patients with azoospermia were analysed using Southern-blot and PCR techniques which detect a total of 25 loci along the $Y$ chromosome. Fifty-four of the patients were cytogenetically normal $(46, \mathrm{XY})$ and the rest showed various structural abnormalities including $46, \mathrm{X}+\mathrm{mar}$ ( 6 cases), $45, X / 46, X+\operatorname{mar}(3$ cases) and 46,X,i(Yp) (1 case). To our surprise, 6 of the 54 patients with a $46, X Y$ karyotype had a minute deletion on DNA analysis. The remaining 10 cases, had different segments of the $\mathrm{Y}$ chromosome. The AZF region was mapped within a small segment. 


\section{A 74}

CLINICAL AND MOLECULAR STUDY OF TWO CASES OF X+mar. Masahiko TSUDA ${ }^{1}$, Yuichi KISHIMOTO $^{2}$, Tatsuhiko URAKAMI ${ }^{1}$, Hiroki NAKABAYASHI ${ }^{1}, 3$, Takeshi SAKIYAMA $^{1}$, Kenya YAMAGUCHI ${ }^{2}$, Mariko ESUMI ${ }^{3}$, Teruo KITAGAWA ${ }^{1}$ and Kiyoki $\mathrm{OKADA}^{2}$, 1: Dept. of Pediatrics, 2: Dept. of Urology, 3: Medical Research Institute, Nihon Univ. School of Medicine, Tokyo, Japan

Two cases of 46, Xtmar male were presented. First case had IDDM, mild bone deformity, and short stature. Cytological analysis revealed 46,

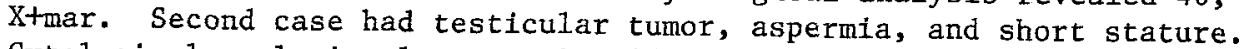
Cytological analysis also revealed 46 , Xtmar. Using synthetic oligonucleotides and other probes such as ZFY and 50f2. We have identified these marker chromosomes were $Y$ short arms including SRY, ZFY region and also centromere. These results support the hypothesis that $\mathrm{Yq}$ has azoospermic factor gene and gene controling stature. We also suggest that deletion of Yq may be the risk factor for developing
tumor.

\section{A 75}

SEX-DETERMINING REGION Y (SRY) IN A PATIENT WITH 46, XX TRUE HERMAPHRODITISM

Akito TANOUE, Toshiro NAKAMURA, Fumio ENDO, Soruku NISHIYAMA, and Ichiro MATSUDA (Department of Pediatrics, Kumamoto University Medical School, Kumamoto 860 , Japan)

Using a polymerase chain reaction method, a search for Y-specific DNA sequences was made in samples derived from tissues of a 46 , XX true hermaphrodite. We found a sequence of SRY in the ovotestis, skin and leukocytes. Other DNA sequences, which covered the pseudoautosomal boundary region, amelogenin gene and DYZ1 locus of Y-chromosome were not detected. The SRY gene detected in the patient by polymerase chain reaction was not detected by Southern blot analysis, using the SRY fragment as a probe.

These findings suggest that in the patient there is a mosaicism of cells with and without part of the $Y$ chromosome, including the SRY sequence. As the SRY sequence was responsible for the development of the gonadal primordium to the ovotestis, SRY seems essential for gonadal differentiation in testis development. 


\section{A 76}

ESTIMATION OF THE RATIO OF FETAL TO MATERNAL CELLS IN MATERNAL PERIPHERAL BLOOD USING IN SITU HYBRIDIZATION TECHNIQUE.

Hiromi HAMADA*, Tadao ARINAMI**, Takeshi KUBO*, Hideo HAMAGUCHI** and Hirokazu IWASAKI* (*Department of Obstetrics and Gynecology, Institute of Clinical Medicine, and **Department of Medical Genetics, Institute of Basic Medical Sciences, University of Tsukuba, Ibaraki)

To estimate the changes in the ratio of fetal to maternal nucleated cells in maternal peripheral blood during pregnancy, cells with the $Y$ chromosome were searched for microscopically in 35 pregnant women carring male fetuses and 15 carring female fetuses. The $\mathrm{Y}$ chromosome was detected by fluorescent in situ hybridization of a Y specific repetitive sequence of the DYZ1 family, and 47,000-157,000 nucleated cells were examined in each subject. Cells with the hybridization signal were detected in all pregnant women carring male fetuses after 15 weeks of pregnancy. The frequencies of cells with the signal ranged from $1: 144,000$ to $1: 4,000$ with a tendency of increasing during pregnancy. Only two positive cells were found among 777,000 cells examined in 8 pregnant women before 15 weeks of pregnancy. Possible false positive result was produced in one woman carring female fetus. These results suggest that the ratio of fetal to maternal nucleated ce11s in maternal peripheral blood is less than 1:100,000 in the first trimester and increase during pregnancy to about $1: 10,000$ at term.

\section{B 1}

\section{TISSUE-SPECIFIC AND DEVELOPMENTALLY REGULATED EXPRESSION OF GENES ENCODING ADENYLATE KINASE ISOZYMES}

Tsuyoshi TANABE, Mamoru YAMADA, Takafumi NOMA, and Atsushi NAKAZAWA (Dept. Biochem., Yamaguchi Univ., Ube)

Adenylate kinase is known to play an important role in the homeostasis of adenine nucleotide metabolism. We determined the tissue-specific distribution of three isozymes of adenylate kinase ( AK1, AK2, AK3) and their mRNAs in the rat. AK1 mRNA was mainly found in the muscle, heart and the brain, while AK2 mRNA was mainly present in the liver, kidney, appendix and the colon. The activity of AK1 and AK2 paralleled the amount of respective tissues studied. The amount of AK 3 mRNA was fairly constant among various tissues. AK1 mRNA in rat muscle during development increased with increasing fatal and early poatnatal age, whereas AK3 mRNA in muscle remained constant during tha same period. AK2 and AK3 mRNAs in rat liver were constant during fatal and postnatal life. 


\section{B 2}

NOVEL GENE ORGANIZATION OF HUMAN CYTOKINE LD78.

Mitsuyoshi NAKAO (Dept. Pediatr., Kurume Univ., Kurume), Hisayoki NOMIYAMA (Dept. Biochem., Kumamoto Univ., Kumamoto), Akinori KIMURA (Dept. Genet., Kyushu Univ., Fukuoka) and Kazunori SHIMADA (Res. Institute Microbial Dis., Osaka Univ., Osaka)

LD78 is a member of a newly identified superfamily of chemotactic, inflammatory and growth regulatory cytokines. Southern blot analysis of EcoRI-digested human genomic DNAs, using LD78 cDNA as a probe, showed that in each individual there are 4.2- and 4.8-kb fragments and that some have an additional 6.5-kb fragment. The 4.2-kb, 4.8-kb and 6.5-kb fragments contained genomic DNA sequences of LD78 $\alpha$, LD78 $\beta$ and LD78 $\gamma$ genes we named, respectively. The LD78 $\beta$ gene showed 95 $\%$ homology to the LD78 $\alpha$ gene. The LD78 $\alpha$ gene was present in a single or a few copies per haploid genome, whereas the copy number of the LD78 $\beta$ and the LD78 $\gamma$ gene varied among the samples tested. Multiple copies of the LD78 $\beta$ and $\gamma$ genes may have been generated by DNA duplication and subsequent unequal crossingover events, which is similar to the proposal to explain the variation in copy numbers of the visual pigment genes observed among normal individuals.

\section{B 3}

INDUCTION OF CELLULAR SENESCENCE IN IMMORTALIZED CELLS BY CHROMOSOME TRANSFER.

Mitsuo OSHIMURA (Dept. of Mol. \& Cel1 Genet., Sch. of Life Sci., Tottori Univ., Yonago)

Two main theories of cellular senescence have been proposed. One is the error catastrophe mode1, which proposes that accumulation of random damage or mutations results in the loss of proliferative capacity. A second hypothesis is that senescence is a genetically programmed process. In order to test the hypothesis, we performed chromosome transfer experiments via microcell-fusion into a variety of immortal cell 1 ines. The introduction of a single copy of human chromosome 1 to a Syrian hamster cell Tine (10W) and a human uterine endometrial carcinoma cell line (HHUA) caused typical signs of cellular senescence. Transfer of chromosome 11 to a human bladder carcinoma cell line had also the effect.

These findings support a genetic basis for cellular senescence. 


\section{B 4}

ORIGIN OF JAPANESE INFERRED FROM ANCIENT AND CONTEMPORARY HUMAN MITOCHONDRIAL DNA. Satoshi HORAI, Rumi KONDO, Kumiko MURAYAMA and Seiji HAYASHI (Dept. Human Genet., National Inst. Genetics, Mishima)

Nucleotide sequence (482 bp) of the major noncoding region of human mitochondrial DNA (mtDNA) was analyzed for 128 contemporary humans from five ethnic groups (African, Caucasian, Japanese, Asian and American). Nucleotide diversity of the region is ca. $1.46 \%$, i.e. three times higher than the value from restriction-enzyme analysis of the whole mtDNA genome. Phylogenetic analysis indicated that Africans are highly diversified with one another and that overall Asians including Japanese can be separated into two distinct groups. For the highly polymorphic region (190 bp), the nucleotide sequences from 11 ancient Japanese bones (from Jomon Age; 3,000 - 6,000 years B.P., and the early modern Ainu; 200 300 years B.P.) were compared together with those from contemporary humans. The nucleotide diversity among the 139 sequences in this region was $2.26 \%$. All of the ancient Japanese were clearly placed in one of large clusters, indicating their genealogical difference from another group of contemporary Japanese. Moreover, a group of ancient Japanese, including both Jomon peoples and the Ainu, showed a close phylogenetic affiliation with one group of contemporary Japanese as well as that of Southeast Asians. This observation supports the immigration theory, which postulates that immigrants from the Asian continent made a considerable contribution to the formation of modern Japanese.

\section{B 5}

IMMUNOGLOBULIN C $\alpha$ GENE CONVERSION IN HUMAN EVOLUTION. Shohii KAWAMURA Shintaroh UEDA (Dept. Anthropology, Fac. Sci, Univ. Tokyo, Tokyo), and Naruya SAITOU (Natl. Inst. Genet., Mishima)

Gene conversion of human immunoglobulin alpha genes (C $\alpha 1$ and $\mathrm{C} \alpha 2)$ was examined by comparing their genomic nucleotide sequences to those of apes (chimpanzee, gorilla, orangutan and gibbon) and Old World monkey (crab-eating macaque). The following three methods were used to detect gene conversions: 1) construction of the phenetic gene tree, 2) detection of the gene region which has extremely low variability between $\mathrm{C} \alpha 1$ and $\mathrm{C} \alpha 2$ genes under the assumption of random distribution of varied sites, and 3) site-by-site search of shared nucleotide changes between the two genes. These analyses revealed that the concerted evolution of the two $\mathrm{C} \alpha$ genes has occurred through frequent gene conversions between them since the gene was duplicated in the common ancestor of human and apes. Converted regions were identified all over the gene region excluding a few sites in the coding region which escape from gene conversion. This indicates that gene conversion is a general phenomenon in evolution, especially observed in nonfunctional regions. 
B 6

\section{SELECTION OF TRANSGENIC MOUSE EMBRYOS BY G418 AT PREIMPLANTATION STAGE. \\ Shoii WAKASUGI, Tadashi KANAME, Satoshi SUGAl, Hisamitsu ISHIHARA and Ken-ichi YAMAMURA (Inst. Med. Genet., Kumamoto Univ., Kumamoto)}

It may be possible to carry out gene trap at preimplantation stage if we could select mouse embryos which integrate the injected DNA into the genome. We used neomycin resistant gene as a selection marker. All embryos died at the blastocyst stage if cultured in the presence of more than $125 \mu \mathrm{g} / \mathrm{ml}$ of G418 from the 2-cell stage. In this experiment, MC1neo gene was injected into pronuclei of 2875 mouse eggs, and these eggs were cultured in the presence of $200 \mu \mathrm{g} / \mathrm{ml}$ of G418. Five hundred and twenty two eggs were survived to the blastocyst stage. These blastocysts were transferred to uteri of foster mothers, and fifty seven pups were born. Twenty-nine pups (50\%) were transgenic in contrast to about $25 \%$ in control experiment. These results indicate that mouse embryos can be selected at the preimplantation stage by $\mathrm{G} 418$, and that gene trap can be done at this stage by microinjecting the promoterless neo gene into the mouse embryos.

\section{B 7}

Isolation of differentiation-related gene by gene tagging method. Shin-ichi Taniguchi, Hitoshi Niwa, Kimi Araki and Ken-ichi Yamamura (Institute for medical genetics, Kumamoto Univ. Med., Kumamoto)

Gene tagging is the ideal method to isolate unknown genes which work in development. Using this technique, we have isolated a novel gene, Ayu-1, the expression of which decreases under RA treatment or embryoid body formation in ES cells. Ayu-1 $5^{\prime}$ flanking sequence contains two En like and Octamer binding motifs. Gel shift assay indicates that these motifs specifically bind to Oct-3

To examine the tissue distribution of Ayu-1 gene expression, we performed Northern hybridization using a probe derived from 3' end of Ayu-1 gene. Two alternative transcripts $(13 \mathrm{~Kb}$ and $9 \mathrm{~Kb})$ were observed in brain, duodenum, and testis. We could not generate chimera mouse using Ayu-1 ES clone. So we have made transgenic mice with Ayu-1 promoter- lacZ construct in order to examine tissue specific expression of Ayu-1 gene. In several transgenic lines, the reporter gene expression was observed in specific neural cells in cerebral posterior lobe and ganglion cells in duodenum. In conclusion, a novel gene Ayu-1 seems to play a significant role both in early development and in neural system. 
B 9

IMMUNOLOGICAL FUNCTION OF DIFFERENTLY EXPRESSED DR $\alpha$ E $\beta$ MOLECULES IN THREE LINES OF HLA-DRA TRANSGENIC MICE. Yoshinori FUKUI, Yukio ESAKI, Ken YAMAMOTO, Akinori KIMURA, Katsuiku HIROKAWA*, Yasuharu, NISHIMURA and Takehiko SASAZUKI (Dept.Gent.,Med.Inst.Bioreg., Kyushu Univ., Fukuoka) *(Dept.Pathology,Tokyo Metropol.Inst.Gerontol, Tokyo)

MHC class $I I$ molecules play a central role in immune regulation to select $T$ cell repertoire and to present foreign antigen to $T$ cells. These molecules are expressed on immunocompetent cells such as $B$ cells (B), macrophages(M), dendritic cells(DC) and thymic epithelial cells (TE). However, immunological function of MHC class $\Pi$ molecules expressed on each cell remains unclear. We have established three lines of HLA-DRA transgenic mice. The DR $\alpha E \beta$ molecules were expressed on B,M,DC and TE in a line 24 and were expressed on TE and a limited proportion of $\mathrm{B}$ cells in a line 60. On the other hand, $\mathrm{DR} \alpha \mathrm{E} \beta$ molecules were only expressed on TE in a line 30. DR $\alpha \mathrm{E} \beta$ molecules expressed on spleen cells from 24 presented MCC81-103 peptide efficiently to MCC81103 specific $T$ cell hybridoma. Weak but definite presentation of the peptide was observed in the line 60 but not in 30 . Thus, in the line 30, little or no expression of $\mathrm{DR} \alpha \mathrm{E} \beta$ molecules were observed on bone marrow-derived cells. To our surprise, the same degree of deletion of $T$ cells bearing TCR VB5 or VB11 was observed in three lines of transgenic mice, indicating that thymic epithelial cells may be responsible for the deletion of $T$ cells bearing TCR VB5 or VB11 or very small amount of $\mathrm{MHC}$ class $\mathrm{molecules}$ expressed on bone marrowderived cells may be sufficient for $V \beta$ specific deletion.

\section{B 10}

SELF TOLERANCE IN THE TRANSGENIC MICE WITH HLA-DRA ON $X$ CHROMOSOME, Ken YAMAMOTO, Yoshinori EUKUل, Yukio ESAKI. Akinori KIMURA, Yasuharu NISHIMURA and Takehiko SASAZUKI, Dept. of Genet. Med. Inst. of Bioreg., Kyushu University, Fukuoka, JAPAN

We have established a line of HLA-DRA transgenic C57BL/6 mouse (DR $\alpha$-B6) in which transgene was integrated into $X$ chromosome. In the $D R \alpha-B 6, D R \alpha E \beta$ xenogenic mixed isotype molecules were expressed in a tissue specific manner and functioned as MHC. The DR $\alpha$-B6 acquired T cell responsiveness to moth cylochrome $C$ and clonal deletion of I-E reactive TCR V 35 or V $\beta 11$ positive Tcells was observed. In female mice hemizygous for HLA-DRA(DR $\alpha-B 6, F$ hemi), the proportion of $D R \alpha E \beta$ positive cells varied due to random inactivation of one of the $X$ chromosomes. And in these mice, the degree of clonal deletion was correlated to the proportion of $D R \alpha E \beta$ positive cells in spleen. Interestingly, in primary mixed lymphocyte culuture, the $\mathrm{DR} \alpha-\mathrm{B} 6, \mathrm{~F}$ hemi in which the clonal deletion was incomplete acquired the immunological tolerance to $D R \alpha E \beta$ molecule as female homozygous and male transgenic mice. When TCRs were crosslinked with anti-V $\beta 5$ or V 311 monoclonal antibodies, T cells from B6 responded vigorously whereas T cells from some DR $\alpha$-B6 $F$ hemi showed only weak response as observed in T cells from DR $\alpha$-B6 F homo in the absence of exogenous IL2. However, T cells from these mice responded to the same magnitude in the presence of exogeneous IL2. Therefore the residual V $B 5$ or V $\beta 11$ positive $T$ cell repertoire escaped from clonal deletion seemed to be anergic in $\mathrm{DR} \alpha-\mathrm{B} 6, \mathrm{~F}$ hemi. We demonstrated the two mechanisms of self tolerance in T cells, clonal deletion and clonal anergy, in the transgenic mice in which the expression of HLA-DRA gene was affected by lyonization. 


\section{B 11}

FUNCTIONAL EXPRESSION OF HLA-DQw4 GENES IN A LINE OF TRANSGENIC C57BL/6 MOUSE. Y.ESAKI, Y.FUKUI, K.YAMAMOTO, A.KIMURA, K.HIROKAWA*, Y.NISHIMURA and T.SASAZUKI, (Dept. Genet., Med. Inst. Bioreg., Kyusyu Univ., Fukuoka, and *Dept. Pathol., Tokyo Metropolitan Inst. Gerontology, Tokyo)

We reported the establishment of a line of transgenic C57BL/6 mouse (B6) expressing both HLA$D Q w 4 A$ and $B$ genes (DQw4AB-B6) last year. In order to investgate a role of $H L A-D Q$ genes in immune reguration, We analyzed the expression and the function of DQw4 genes in DQw4AB-B6. HLA-DQw4 molecules were expressed in a tissue specific manner depending on the tissue specfic expression of $\mathrm{DQw} 4 \mathrm{~A}$ gene in the $\mathrm{DQw} 4 \mathrm{AB}-\mathrm{B} 6$. Immunohistochemical staining of thymus from $\mathrm{DQw} 4 \mathrm{AB}-\mathrm{B} 6$ has shown that $\mathrm{DQw} 4$ molecules are mainly expressed in the medulla as compared with the expression of I-A molecules. The DQw4AB-B6 acquired an immunological torelance to DQw4 molecules and distinguished DQw4 molecules from DQw6 molecules as evidenced from antibody production. Spleen cells from an umprimed DQw4AB-B6 expressing only a small amount of DQw4 molecules exhibited a marked proliferative response to a streptococcal superantigen, pepM12 prepared by digestion by pepsin of streptococcal M12 protain, while spleen cells from an unprimed B6 did not. The proliferative response of umprimed T cell to pepM12 was also evidenced in a DQw4A single transgenic mouse. It was suggested that superantigen pepM12 interacted with DQw $4 \alpha$ chain and T cell receptor to induce proliferation of $T$ cells. This data indicated that the HLA-DQw4 molecules functioned as MHC at least in part in the DQw4AB-B6.

\section{B 12}

GENETIC ANALYSIS OF TRANSIENT HYPERGLYCEMIA IN NOD MICE TRANSGENIC FOR INSULIN-SV40 T ANTIGEN GENE.

Jun-ichi MIYAZAKI, Fumi TASHIRO (Dept. Disease-related Gene Reg. Res. (Sandoz), Fac. Med., Univ. Tokyo, Tokyo) and Ken-ichi YAMAMURA (Inst. Med. Genet., Kumamoto Univ., Kumamoto)

We previously made transgenic mice by introducing insulin promoter-SV40 Tag gene into C57BL/6 mouse eggs. These mice repeatedly developed $\beta$ cell tumors at the age of $\sim 12$ weeks. When one line of these mice was crossed and further backcrossed to NOD mice several times, the progeny exhibited hyperglycemia (blood sugar $>500 \mathrm{mg} / \mathrm{dl}$ ) at $4 \sim 6$ weeks of age, but gradually became hypoglycemic due to the development of $\beta$ cell tumors. The mechanism for this transient hyperglycemia seemed distinct from autoimmune diabetes. Genetic analysis was performed by crossing them with other inbred strains of mice. The result showed that this hyperglycemia is controled by a single recessive gene which is unlinked to $\mathrm{H}-2$, suggesting that this gene may be related to one of the diabetes susceptibility genes (Idd-3,Idd-4 and $I d d-5)$. 


\section{B 13}

DETECTION OF A MIS-SENSE MUTATION IN EXON 17 OF THE AMYLOID PRECURSOR PROTEIN GENE IN JAPANESE ALZHEIMER'S DISEASE, Satoshi NARUSE, Shuuichi IGARASHI, Hisashi KOBAYASHI, Kiyotoshi KANEKO (Dept. Neurol., Brain Res. Inst., Niigata Univ., Niigata), Teruo SHIMIZU (Dept. Neurol., Faculty of Med., Tokyo Univ., Tokyo), Imaharu NAKANO (Dept. Neuropath., Faculty of Med., Tokyo Univ., Tokyo), Takeshi KOJIMA (Dept. Psych., Horinouchi Hosp., Saitama), Tadashi MIYATAKE (Dept. Neuro1, Tokyo Med. Dent. Univ., Tokyo) and Shoii TSUJI (Dept. Neurol., Brain Res. Inst., Niigata Univ., Nigata)

Recently Goate et aI. have identified a mis-sense mutation (Val to Ile) in exon 17 of the amyloid precursor protein (APP) gene in 2 of 16 early-onset familial Alzheimer's disease (FAD) families. To determine if the mis-sense mutation is observed in different ethnic origin, we have studied 4 early-onset Japanese FAD cases from 4 unrelated families. Two of the 4 early-onset FAD patients showed the existence of the mutation. The mutaion was not observed in 2 late-onset FAD cases, 20 sporadic Alzheimer's disease cases or 50 normal individuals. The result indicates that the mutation is a cause of FAD. We have also studied exons 7 and 16 of the APP gene in 4 early-onset FAD patients and 2 late-onset FAD patients but failed to detect any mutations.

\section{B 14}

MORTALITY RATE OF ALZHEIMER'S DISEASE IN JAPAN. Yoko IMAIZUMI

(Inst. of Population Problems, Ministry of Health and Welfare, Tokyo)

The present study deals with the secular changes and the geographical variations in the Alzheimer's disease (AD) death rate during the period from 1979 to 1990 . It also deals with the effects of marital status and occupation of the head of the household on the $\mathrm{AD}$ death rate during the period from 1979 to 1985. Data consisting of $931 \mathrm{AD}$ deaths reported for 1979-1990 inclusive have been obtained from the death certificate records kept at the Ministry of Health and Welfare. The $A D$ death rate has increased gradually year by year for both sexes. The overall death rates per 100,000 population 35 years and over were 0.127 for males and 0.144 for females. Age-specific AD death rate increased exponentially up to the 65-69 age group and decreased thereafter. There were remarkable differences in the AD death rates among the four marital categories and among the six occupational categories. As for the geographical variations, the highest death rate was seen in Miyazaki prefecture (0.291), followed by Tokushima $(0.287)$, and Ishikawa $(0.269)$ prefectures. The lowest death rate $(0.037)$ was seen in Okinawa prefecture, followed by Saga $(0.058)$ and Miyagi $(0.075)$ prefectures. Overall mean age at death was 63.5 years for males and 65.3 years for females. 


\section{B 15}

A GENETIC STUDY OF SPONTANEOUS OCCLUSION OF TEE CIRCLE OF WILLIS(MOYAMOYA DISEASE) Nobuko KANAI, Makiko OSAWA, Yukio FUKUYAMA (Dept. Pediatr., Tokyo Women's Medical College., Tokyo) Yasuhiro YONEKAWA (Dept. Neurosurg., National Cardiovascular Center., Osaka)

A genetic study of moyamoya disease was carried out, using information obtained from a nationwide epidemiological survey of moyamoya disease conducted from 1983 to 1989. Reliable data on 513 families, including 37 families referred to our department, were obtained. In addition, we confirmed family histories and gathered additional information by questionnaire. The percentage of families responding to the questionnaire was 58.0\%. Consanguinity and familial occurrence were observed in 13 (2.7\%) and 42 families (8.8\%) respectively. The recurrence rate in siblings was 2.88 , abut 40 times that of the general population $(0.007 \%)$, we analyzed 13 twin pairs, including 12 in a review of the literature. In monozygotic cases, 8 of 10 twin pairs were concordant for moyamoya disease. The recurrence rate in children of probands was $2.4 \%$, 34 times that of the general population. The relative incidence in siblings and children approximated the value expected from multifactorial inheritance. The mode of inheritance of moyamoya disease is considered to be multifactorial. based on the lower recurrence rate in siblings and children than would be expected from simple Mendelian inheritance. However, the higher incidence among family members, particularly twins, clearly indicates a genetic predisposition for moyamoya disease.

\section{B 16}

A STUDY OF THE PSEUDO-AUTOSOMAL REGION IN SIB-PAIRS WITH SCH I ZOPHREN I A

Toru ISHIDA, Hiroshi YONEDA, Yasuhiro NONOMURA Yasuhiro INAYAMA, Yoshihiro KONO and Toshiaki SAKA I (Dept. Neuropsychiat., Osaka Medical College, Takat suki, Osaka)

One of the regions suspected of being the source of schizophrenia is the pseudo-autosomal region. We investigated sex distribution of $73 \mathrm{sib-}$ pairs, both of whom were diagnosed as having schizophrenia. Thirty nine pairs were of the same sex and 34 were of opposite sexes. The sex ratio showed no significant difference. We divided the 73 pairs into 4 groups by the pattern of familial transmission of schizophrenia. The 4 groups showed no difference in sex ratio. We studied 26 eases with schizophrenia and 150 healthy controls to investigate the association between schizophrenia and the alleles of restriction fragment length polymorphisms(RFLPs) at DXYS 17 in the pseudo-autosomal region. The allele frequencies at DXYS 17 did not show any significant differences between the two groups. These findings would indicate that the pseudo-autosomal region does not contribute to the development of schizophrenic symptoms. 


\section{B 17}

CLASSIFICATION OF OBSESSIVE-COMPULSIVE NEUROSIS IN CHILDHOOD AND ADOLESCENCE.

Yoko NAGAI, Shingo YOKOTA, Hiroshi YONEDA, Takako OZAKI, Toshiaki SAKAI (Dept. Neuropsychiat., Osaka Medical College, Takatsuki, Osaka)

The aim of this study is to clarify obsessive-compulsive neurosis form a disease with a single entity or not. We studied age of onset, personality, symptoms, clinical course, outcome and intrafamilial psychopathological traits of 47 ( 27 males and 20 females) patients with age 9-19 years. On the basis of the data obtained, the cases were divided into three types by the use of a multivariate analysis (Hayashi's third method of quantification). The features of these three types are as follows:

Type 1: anthoropophobia, poor outcome and traits of schizophrenia.

Type 2: mysophobia with compulsive washing, poor outcome and traits of character abnormality.

Type 3: various symptoms, good outcome, traits of affective disorders and no pathological traits.

The study revealed that cases of obsessive-compulsive neurosis consist of several subtypes that differ in clinical features and genetic background. Thus, this neurosis is considered to be heterogeneous.

\section{B 18}

POLYMORPHIC POLYPEPTIDE IN HUMAN PLATELETS DETECTED BY TWO-DIMENSIONAL ELECTROPHORESIS. Sadahiko IWAMOTO, Eiji KAJII, Toshinori OMI. Takashi OYAMADA, Emiko FUKUI, Syuuichi TSUCHIDA, \& Shigenori IKEMOTO (Dept. Legal Med. \& Hum. Genet., Jichi Med. School, Tochigi)

A genetic polymorphism of human platelet polypeptide with a molecular weight of $28 \mathrm{kd}$ detected by two-dimensional electrophoresis was investigated on its family and population studies, linkage analysis with other 26 polymorphic markers and cell distribution. The $28 \mathrm{kd}$ polypeptide showed autosomal co-dominant inheritance of two alleles. The gene frequencies of the two alleles were 0.925 and 0.075 , respectively. The $28 \mathrm{kd}$ polypeptide had no obvious genetic linkage with otherr polymorphic phenotypes. It was observed in lymphocytes. neutrophils, eosinophils, and monocytes in addition to platelets, but not in erythrocytes. In liquid culture system, human normal erythroid cells expressed the $28 \mathrm{kd}$ polypeptides on early maturation stage and lost them on later stage. 


\section{B 19}

POLYMORPHISM OF HUMAN PLATELET MEMBRANE GLYCOPROTEIN IIIA ASSOCIATED WITH THE YUK ${ }^{A} / Y_{U K}{ }^{B}$ ALLOANTIGEN SYSTEM. Li WANG, Takeo JUJI, Shoji KUWATA, Katsushi TOKUNAGA (Dept. Transfus. Med. Immunohaematol,, Univ. Tokyo) and Yoichi SHIBATA (Dept. Immunohaematol., Toranomon Hosp.)

The human platelet alloantigens, $Y k^{a}$ and $Y_{u k} b$, located on the platelet fibrinogen receptor, membrane glycoprotein (GP) IIla, appear to play an important role in provoking neonatal alloimmune thrombocytopenic purpura and posttransfusion purpura in Japanese population. Moleculat definition of Yuk alloantigenic determinants is as yet unknown. To investigate whether phenotype-specific nucleotide sequence polymorphism exist in the GPIlla gene, ye used the polymerase chain reaction (PCR) to amplify GPIIla cDNAs from $Y_{\text {uk }}{ }^{a / a}$ and $Y u k^{b / b}$ homozygous individuals. The direct nucleotide sequencing analysis of amplified cDNA products revealed a single nucleotide substitution at base 526 of GPIIIa cDNA. This base change results in an amino acid polymorphism at residue 143 of glycoprotein IIIa molecule. The Yuka form of GPIIIa mRNA bears the codon CAA(Gln143) in place of the $\mathrm{CGA}\left(\mathrm{Arg}^{143}\right)$ in the $\mathrm{Yuk}^{\mathrm{b}}$ allele. Slot blotting analysis using oligonucleotide probes containing the putative phenotye-specific base in the middle demonstrated that this Arg/Gln polymorphism is associated with the Yuk alloantigen system.

\section{B 20}

\section{IDENTIFICATION OF A COMMON MUTATION IN FINNISH PATIENTS WITH NONKETOTIC HYPER GLYCINEMIA. Shigeo Kure, Masaru Takayanagi, Kuniaki Narisawa, Keiya Tada*, and Jaako Leisti §. Department of Biochemical Genetics and Pediatrics*, Tohoku University School of Medicine, Sendai, Department of Clinical Genetics\$, Oulu University Central Hospital, Finland.}

Nonketotic hyperglycinemia (NKH) is a rare autosomal recessive metabolic disorder in many countries, but with a very high incidence in nothern Finland. To understand the genetic background of this high incidence we examined the glycine cleavage system (GCS) in a typical case of NKH at the molecular level. The activity of Pprotein, a component of the GCS, was not detected in the lymphoblasts of the patient, while P-protein mRNA of a normal size and level was present in the cells. Structural analysis of $P$-protein $m R N A$ from the patient revealed a single nucleotide substitution from $G$ to $T$ in the protein coding region, which resulted in an amino acid alternation from Ser564 to Ile564. No P-protein activity was detected when the mutant P-protein with this amino acid substitution was expressed in COS 7 cells. The patient was homozygous for this mutation in his $\mathrm{P}$-protein gene. Furthermore, this mutation was present in $70 \%$ (14 of 20) of P-protein gene alleles in Finnish patients with NKH. No allele with this mutation was found in 20 alleles of non-Finnish patients. The results suggest that this mutation is responsible for the high incidence of NKH in Finland. 


\section{B 21}

SPECIFIC ACTIVITY OF RESIDUAL CATALASE IN THE BLOOD OF JAPANESE AND MOUSE ACATALASEMIA. Mas ana OGATA ${ }^{\mathrm{T}} \cdot 2$ and Yasuhi to FUJII ${ }^{2}\left({ }^{1}\right.$ Dedt.Med.Soc. Work, Kawasaki Univ.Med. We leare,Kurasiki; ${ }^{2}$ Dept. Public Health, Okayama Univ.Med.Sch. Okayama)

Catalase in hemolysates of normal, heterozygous hypocatalasemic and acatalasemic Japanese was immunotitrated with an anti-human blood catalase rabbit serum. Catalase activities at the equivalence points of Japanese normal, hypocatalasemia and acatalasemia were simslar. The results indicates that the specific activities of catalase in normal and the variant bloods are identical, because catalase protein concentrations in the hemolysates at equivalence points are almost equal. Catalase in hemolysates of normal and variant mice was immunotitrated with an anti-mouse $7 i v e r$ catalase rabbit serum. In contrast to Japanese acatalasemic subject, the ratios of equivalence point of catalase in heterozygous hypocatalasemic, homozygous hypocatal asemic and acataTasemic hemolysates to that in normal hemolysates, which express the ratios of specific activity in variant mice to that in normal, were $0.72,0.47$ and 0.21 , respectively. The result suggests that the molecules properties of residual catalases between Japanese and mouse acatalasemias are entirely different.

\section{B 22}

CHROMOSOME MAPPING OF THE HUMAN MITOCHONDRIAL ACETOACETYL-COENZYME A THIOLASE GENE TO BAND 11q22.3-q23.1 BY FLUORESCENCE IN SITU HYBRIDIZATION. Mitsuo MASUN0 ${ }^{1}$, Masatsugu KAN0 ${ }^{1}$, Toshiyuki FUKA0 $^{1}$, Seiji YAMAGUCHI ${ }^{1}$, ${\text { Takashi } \text { OSUMI }^{2} \text {, Takashi HASHIMOTO }}^{3}$, Ei-ichi TAKAHASHI ${ }^{4}$, Tada-aki HORI ${ }^{4}$, Tadao ORII ${ }^{1}$ ('Dept. Pediatr., Gifu Univ. Sch. Med., Gifu; ${ }^{2}$ Dept. Life Sci., Fac. Sci., Himeji Inst. Technol., Hyogo; ${ }^{3}$ Dept. Biochem., Shinshu Univ. Sch. Med., Nagano; ${ }^{4}$ Div. Genet., Nat1. Inst. Radiol. Sci., Chiba)

Beta-ketothiolase deficiency (McKusick 20375) is a genetic disorder of isoleucine and ketone body catabolism that is inherited as an autosomal recessive trait. The disease is caused by a deficiency of mitochondrial acetoacety1-CoA thiolase (EC 2.3.1.9, ACAT). Recently, the ACAT cDNA and gene have been cloned by us. The gene spans about $27 \mathrm{kilobase}(\mathrm{kb})$ in length; it consists of 12 exons and 11 introns (Fukan et al., 1990; Kano et al., in press). The development of an improved technique of fluorescence in situ hybridization, utilizing replicated R-bands by bromodeoxyuridine incorporation after synchronization with excess thymidine, has permitted the direct visualization of fluorescent signals on R-banded prometaphases (Takahashi et al., 1990). A plasmid clone of an 8.2-kb EcoRI genomic fragment of the ACAT gene, containing exon 9 to exon 12 of $i t$, was utilized in chromosomal in situ suppression hybridization. The signals were located on the boundary of 11q22.3-q23.1 (47\%), the proximal end of the band at 11q23.1 (36\%), and the distal end of the band at $11 \mathrm{q} 22.3(17 \%)$. The ACAT gene was mapped to chromosome band 11q22.3-q23.1. 


\section{B 23}

APPLICATION OF RARE CUTTER ENZYME SYSTEMS, BSUE METHYLASE-NOTI AND TAQI METHYLASE-DPNI, TO GENOME MAPPING. Takayuki NAGAOKA (SRL), Yasushi KOBAYASHI, Yukiko YASUKOCHI (Dept. Mol. Genet. Tokyo Med. Dent. Univ.) and Hridayabhiranjan SHUKLA, Hartwig P. ARENSTORF, Sherman M. WEISSMAN (Dept. Hum. Genet., Yale Univ.)

We have used a combination of BsuE methyltransferase (M-BsuE) and NotI restriction enzyme to cut genomic DNA at a subset of NotI sites. The usefulness of this system is shown in a re-examination of the restriction map of the human MHC. Combinations of methylases and restriction enzymes can be used to generate cuts at different frequencies in genomic DNA, such that they generate ends complementary to NotI ends, and can be used in conjunction with NotI linking clones in chromosome jumping experiments. Also we confirmed that digestion of the E. coli genome with TaqI methylase-DpnI system gave distinct bands on PFGE which were as large as digestion with NotI. These enzyme combinations have the potential to produce cutting sites in genomic DNA spaced at intervals favorable for extensive mapping, fragment enrichment, and cloning efforts.

\section{B 24}

CONSTRUCTION AND CHARACTERIZATION OF A NOT-BSUE LINKING LIBRARY FROM THE HUMAN X CHROMOSOME. Yukiko YASUKOCHI, Y. TANAKA, S. KITAJIMA (Dept. Mol. Genet., Tokyo Med. Dent, Univ., Tokyo) and H.P. ARENSTORF, R.P. KANDPAL, N. BASKARAN, S. PARIMOO, S.M. WEISSMAN (Dept. Hum. Genet., Yale Univ.)

We describe the construction and characterization of methylation resistant sequence-tagged NotI linking clones specific for the $\mathrm{X}$ chromosome, referred to as NotI-BsuE linking clones. The approach consists of methylating the $X$-chromosome specific cloned DNA with BsuE methylase, an enzyme which methylates the first $C$ residue in the CGCG sequence, followed by selection of the methylation resistant NotI sites by insertion of the Kanamycin gene in the clones cleavable by Notl. The frequent occurrence of NotI sites in the $\mathrm{CpG}$ islands is expected to cause methylation of a large number of NotI sites with BsuE methylase, thereby rendering them resistant to NotI cleavage. Thus, the combination of BsuE methylase and NotI yields less frequent cutting than the NotI alone. We have isolated, partially sequenced and characterized 114 NotI-BsuE linking clones, and mapped 51 clones to various regions along the chromosome. 


\section{B 25}

HUMAN GENETICS TEACHING IN FACULTY OF MEDICINE. Hirotada TAKASHIMA, Teruo KITAGAWA, Misao OHWADA, Takeshi SAKIYAMA (Dept. Pediat., Nihon Univ., Tokyo)

In recent years, human genetics is under the necessity of educating in medical school curricula. It is the reason that medical students must understand the genetic mechanism, DNA, clinical genetics and so on. The genetics is instructed about $50 \%$ of 80 medical schools in Japan (Hamaguchi, 1988). But, they don't have any genetics administrative unit except a few universities. Therefore, the background of the medical genetics teachers are pediatrician, physician, zoologist and so on. We had 14 hours for medical genetics teaching during a half year in their preclinical faculty. The questionnaire were prepared to medical students in 1988 and 1989. As the result of questionnaire, these medical students showed the great interest to the human genetics, particularly about chromosomal aberration, inborn errors of metabolism, genetic counselling and so on. They mentioned several wishes to the subject of human genetics as below.

(1) more class schedule in curriculum.

(2) take longer hours for genetic practice. Humangenetics teaching is absolutely required for understanding of many diseases which are taken ill by genetics and environment. We think that the human genetics is becoming the root-stock of all fields in medicine.

\section{B 26}

\section{ATTTTUDE TOWARD HANDICAPPED CHILDREN --CONPARISON BETWEEN THEIR PARENTS AND OTHERS}

NAOKO KANOH (Dept.of Nursing,Tokyo Univ.)) Kumiko IIJIMA and Makoto HIGURASHI (Dept.of Maternal and Child Health,Tokyo Univ.)

The phisycally handicapped persons have been paid attention in recent years. Since 1981, the international year of the handicapped persons, lots of administrative measures and publicities have been achieved. But there are still some problems left.

In 1990, we studied what sort of knowledge the people had about congenital defect. We also studied about the problem which the parents of the children with congenital defects had through the medical care and education of their child. 84 parents of Down Syndrome children(DS) and 118 controls including housewives, office ladies and students were surveyed. Many mothers of DS wanted their husbands to participate in the medical care and education of their child more intensively.

There were little gap of knowledge between the parents and the controls. Many of the controls asserted that the relationship of the handicapped and the general should be equal. But, on the other hand, many of the controls said they had no confidence of bringing up the child with a congenital defect if they had in this society. 


\section{B 27}

Informed consents in the genetic counselling. Mitsushiro KIDA (Dept. of Pediat. Teikyo Univ. School of Medicine, Tokyo)

In recent years, the term "infored consent" has been used in various fields of practical medicine. Informed consent is a system where by the doctor informs the patient of the type of treatment method, as well as its merits and demerits, and conducts treatment on the basis of the patient' $s$ will. In recent medical education, however, human genetics has been neglected. For instance, the standard of questions for the national examination for the license of medical practice(1989 edition, Ministry of Health and Welfare) cover seven diseases, including Down's syndrome, but do not cover issues related to the non-disjunction or chromosomal breakage. On the other hand, in practical medicine, it has become easy to examination for abnormalities in the number and stracture of chromosomes, taken from patient material and to sent them directly to practicing doctor of the whole country in commercial base. In this age of DNA anaysis, many problems has been observed frequently, owing to those medical education. Most cases are due to a lack of medical docter' $s$ understanding that human genetics is a science based on individual differences, that abnormality is variety of normality, and that human population always contains some of congenitally abnormal persons. Both patients and parents have right to live, and parents have the right to know about their fetuses by prenatal diagnosis.

\section{B 28}

MARKED INCREASE IN GENETIC COUNSELING AND PRENATAL DIAGNOSIS - AN INTERNATIONAL SURVEY -.

Ichiro MATSUI, Masako TANIMURA (Dept. Child Ecology, Natl. Children's Med. Res. Ctr., Tokyo), Kaoru SUZUMORI (Dept. Obstet. Gynec. Nagoya City Univ., Nagoya)

To better serve a patients with genetic disorders and plan a future genetic service system in Japan, a world-wide survey on the present use of genetic counseling and prenatal diagnosis was conducted. Out of 672 entries in International Directory of Genetic Services (9th Ed.,1990) involved in services for genetic counseling or prenatal diagnosis, 329 responded to our survey, including 167 from the U.S.A. and 162 from 48 other countries.

The use of genetic counseling in 1990 increased markedly (20\% or more) in nearly half the service units in the U.S.A. and in most of the developed countries as compared to 5 years before. Genetic counseling is conducted both by medical doctors and certified genetic counselors (MS, PhD, etc.) in the U.S.A., Canada and England, but only by a medical doctor in other countries. One of the major common problems in maintaining genetic counseling was funding or economical problem at many service units. Prenatal diagnosis cases increased at $80 \%$ of the units, in the U.S.A. and other countries as compared to 5 years before. A marked increase (20\% or more) in use was noted at $30 \%$ of the U.S. units and nearly half the units in other developed countries. The principal method for prenatal diagnosis was amniocentesis with increasing utilization of chorionic villi sampling and chordocentesis in most prenatal diagnostic services. DNA diagnosis was applied for muscular dystrophy, hemoglobinopathy, cystic fibrosis, at more than 40 prenatal diagnosis units. 


\section{B 29}

Three cases with Infantile Marfan syndrome. K.Imaizumi, K.Kurosawa, Y.Kuroki. (Dept. Med. Genet. Kanagawa Children's Medical Center, Yokohama).

Marfan syndrome is one of the most common connective-tissue disorder and its clinical manifestations occur in the skeletal, ocular and cardiovascular systems. Most cases are diagnosed in adolescent or adulthood. However, there have been some severe affected cases with Marfan syndrome diagnosed in the neonatal period. We report here three severe affected infants, all of them died of cardiac disease within one year of age. Clinical manifestations included arachnodactyly, hyperextensible joints, flexion contractures, redundant skin, prominent forehead, deep-set eyes, high arched palate and flattered ears. Cardiovascular abnormalities observed in three patients were polyvalvular prolapse, polyvalvular regurgitations and aortic arch dilatations. Macroscopic examinations showed hypoplastic valves, dilatation of aortic arch, waving aorta and lung emphysema. Microscopically, elastic fibers were apparently fragmented in skin and aortic wall. The high mortality rate and different clinical manifestations suggest that infantile Marfan syndrome may be genetically different from Marfan syndrome.

\section{B 30}

A CASE OF BRACHMANN-DE LANGE SYNDROME WITH SUBPERIOSTEAL ABSCESS OF MANDIBLE. Shiroshi KIKUCHI (Dept. Oral and Maxillofacial Surg., Sch. Med., Teikyo Univ., Tokyo)

Brachmann-de Lange is a syndrome characterized by mental retardation, small stature, microbrachycephaly, hirsutism and limb deformities. This syndrome is a congenital disorder of uncertain cause and genetic markers, but it was not reported details of many anomalies in oral and maxillofacial region. The date of first examination of this case, at the age of 14, a male, was April 1991. [1] Local findings of oral and maxillofacial region: craniofacial hypoplasia (microencephaly, micrognathia, microgenia), small pituitary fossa, hirsutism, bushy eyebrows in continuity (synophrys), curly eyelash, brachyrhinia, anteverted nostril, low set article, downturning corners of mouth (fish-mouth appearance), cleft palate (post operation), high palate, macroglossia, fissured tonge, congenital missing teeth, delayed eruption of teeth, microdontia, hypoplasia of dental arch, malocclusion, severe attrision and hypermyotonia. [2] Clinical diagnosis : subperiosteal abscess of mandible caused by severe attrition of incisors and dental pulpa necrosis. [3] Treatments were abscess incision, drainage, dental pulpa treatments, detecting therapies of severe bruxism, orthognathia and developmental guidance for normal occlusion. 


\section{B 31}

NOONAN SYNDROME WITH HALLUCINATION AND DELUSION OF PERSECUTION. Miho MATSUI, Yutaka MATSUMURA, Koho MIYOSHI (Department of Neuropsychiatry, Hyogo Medical College, Hyogo)

A 42-year-old male with the Noonan syndrome and a psychiatric disorder is reported. His clinical features included congenital heart desease, cryptorchidism, hypogonadism and mental retardation (IQ=75). His karyotype was 46,XY,inv(9)(p11q13). At age 41 years, he had troubles with his work, and was scolded by his brother for a trifling matter. He developed bizarre behaviors, including delusion of reference and persecution and thought broadcasting. He quit his job. When seen by us, he had auditory hallucination, thought insertion, autistic thinking, insomnia and loss of appetite. His borderline intelligence may have played a role in the development of his psychiatric symptoms.

\section{B 32}

PREMATURE AGING, IMMUNODEFICIENCY, MICROCEPHALY, BIRD-LIKE FACE, DEAFNESS, BRACHYDACTYLY AND MENTAL RETARDATION: A NEW SYNDROME ? Hirofumi OHASHI ${ }^{1,2}$, Kyoko FUJITA ${ }^{1}$, Masato TSUKAHARA ${ }^{1}$, Ichiro MURANO $^{1}$, Kiyosato MATSUO ${ }^{1}$, Yoshimitsu FUKUSHIMA ${ }^{2}$, Tadashi KAJII ${ }^{1}$ (Dept. Pediatr., Yamaguchi Univ. Sch. Med., Ube ${ }^{1}$, Div. Med. Genet., Saitama Children's Medical Center, Saitama ${ }^{2}$ )

A 30-year-old woman was referred to us for evaluation of senile appearance, deafness, multiple warts and mental retardation. Her parents are first cousins whose another offspring is physically and intellectually normal. She had repeated upper and lower respiratory infections. Her menses had been irregular and ceased at age 25 years. Clinical features noted were a birdlikeface of senile appearance, microcephaly, multiple nodular warts in the hands, scalp and face, and multiple lentigines and frecklings of the skin. Endocrinological examinations revealed hypergonadotropic hypogonadism consistent with menopausal state. Immunological studies, including blastformation abilities of T-lymphocytes with PHA and Con-A, revealed cellular immunodefíciency. Cultured skin fibroblasts after two passages showed cell doubling time twice as long as a control, and underwent replicative senescence after four passages.

The patter of abnormalities in this patient appears to represent a previously undescribed disorder, probably of autosomal recessive inheritance. 


\section{B 33}

Genetic analysis of Zellweger syndrome

Nobuyuki Shimozawa, Yasuyuki Suzuki, Tadao Orii (Dept. Pediatr., Gifu Univ.,Gifu), Toru Kawai, Hajime Nakamura (Dept.Pediatr., Kobe Univ., Kobe), Toshiro Tsukamoto and YukioFujiki (Meiji Inst., odarara)

Zellmeger syndrome, which is a fatal autosomal recessive disease, is characterized by the absence of peroxisomes and regarded as a prototype of peroxisomal disorders. Although a number of metabolic defects have been elucidated to be linked to this syndrome, its primary etiology is unknown. We found that nine complementation groups rere identified by cell-fusion in collaboration with Kennedy Institute, U.S.A. Furthermore, We isolated three groups of chinese humster ovary (CHO) cell mutants deficient in the assembly of peroxisomes, and cloned, by genetic complementation analysis, a rat cDNA encoding peroxisome assembly factor-1 (PAF-1) that restores the assembly of peroxisomes in one of the CHO mutants. We examined cell-fusion between this mutants and fibroblasts from patients of nine complementation groups of peroxisome-deficient disorders. As a result, we have demonstrated the first human cDNA that complements the defect of peroxisome assembly, in fibroblasts from a patient with Zellweger syndrome, where there is a point mutation causing a premature termination of PAF-1. The patient apparently had a homozygous wutation inherited from her parents who had a heterozygous mutation.

\section{B 34}

TWO SIBLINGS FTH HOLOPROSENSEPHALY. Ts T TOMU YAMANARA ${ }^{1}$, Chi em i HAYAKA Masato NAGASAKA ${ }^{2}$, Yuh TANAKA ${ }^{2}$ (Dept. Pediatr. ${ }^{1}$, Dept. Neurosurg. ${ }^{2}$, Central Hosp., Aichi Pref. Colony, Kasugai), Kiyoshi MIYAZAKI (Dept. Pediatr., Nakatsugawa Municipal Hosp., Nakatsugawa), Kaoru SUZUMORI (Dept. Obst. Gynec., Nagoya City Univ., Nagoya)

Holoprosencephaly is a complex malformation in which impaired midline cleavage of the embryonic prosencephalon leads to a variable deficit of facial development. The etiology is heterogeneous. It usually occurs sporadically but a few cases are familial. We report affected sibs in a fami1y. Case 1: The first child, a boy, was macrocephalic at birth and was diagnosed as alobar holoprosencephaly and hydrocephalus by CT scan and ultrasound studies. He had minimal facial dysmorphism. Case 2: The secound child, a girl, showed spastic signs of extrimities at 3 months of age and was diagnosed as alobar holoprosencephaly as well as her brother. Cytogenetic examinations of the sibs were normal. There were no microforms of holoprosencephaly in the parents. So, we suspected autosomal recessive inheritance in this familial cases. After genetic counseling, the mother was pregnant again. Ultrasound studies at 17 weeks gestation were normal and the third child was born in normal. 
B 35

A CASE OF CARDIO-FACIO-CUTANEOUS SYNDROME WITH CHARACTERISTIC SKIN LESION.

Yukihisa MASUDA, Tadashi KANAME, Kouichi MARUYAMA, Shouzou OKU, and Kouichirou MIYATA (Dept. Pediatr., Kagoshima Univ., Kagoshima )

The patient, the first child of healthy non-consanguineous parents, was born at 40 weeks after non-eventful pregnancy. There was no family history of congenital anomaly or developmental delay. His birth weight was $3,360 \mathrm{~g}(+0.2 \mathrm{SD})$, length $49.6 \mathrm{~cm}(-0.1 \mathrm{SD})$. At 2 months, his mother noticed cafe aulait spots of his left leg and right hand. Heart murmur was pointed out at the three months health exam. At first visit of our hospital, he was diagnosed as Noonan syndrome, having a chacteristic facial appearance with pulmonary stenosis. When he was four years old, he showed relative macrocephaly with bitemporal constrict, a high cranial vault, and curly hair. He had an unusual facial appearence with absent eyebrows; hyperterolism; bilateral ptosis; posteriorly rotated and low-set ears. His skin was dark and hyperkeratotic with cafe aulait spots and hyperpigmented spots. The skin biopsy revealed hyperpigmentation in the basal layer of epidermis, and mild increase of collagen fibers upto the subcutaneous adipose tissues.

\section{B 36}

GENETIC ANALYSIS OF APOLIPOPROTEIN(a) ISOFORM PHENOTYPES AND PLASMA LP(a) CONCENTRATION. Shu-ichi KIKUCHI', Yoshimi KOZU, Akiko NAKAGAWA ${ }^{1}$, Hisako YANAGI ${ }^{1}$, Kimiko KOBAYASHI ${ }^{1}$, Shigeru TSUCHIYA ${ }^{2}$ and Hideo HAMAGU-CHI ${ }^{1}$ ('Dept. Med. Genet. ${ }^{2}$ Inst. Comm. Med., Univ. Tsukuba, Tsukuba)

Apolipoprotein(a) (apo(a)) is an important constituent of lipoprotein(a) (Lp(a)) and individual differences in molecular sizes of apo(a) are inversely correlated with plasma Lp(a) levels. To develop a sensitive method for the analysis of apo(a) phenotypes and to determine the mode of inheritance of apo(a) isoforms, apo(a) in plasma lipoprotein fractions was analyzed by SDS/PAGE followed by immunoblotting with a monoclonal apo(a) antibody in 29 Japanese families, 212 unrelated healthy adults, and 70 patients with coronary heart disease (CHD). A total of 23 different apo(a) isoforms could be resolved.Only 1 or 2 apo(a) isoforms were present per individual and autosomal codominant inheritance of apo(a) isoforms were observed in family studies. It was suggested that the distribution of phenotypes in unrelated healthy subjects is consistent with the Hardy-Weinberg equilibrium. The smallest size group of apo(a) isoforms was associated with high plasma $L p(a)$ levels and the largest size group of apo(a) isoforms was associated with very low $L p(a)$ levels. Frequencies of subjects with high plasma Lp(a) levels and small sizes of apo(a) were higher inpatients with CHD than in healthy adults. 
DNA SEQUENCE ANALYSIS OF MUTANT LDL RECEPTOR GENES IN FAMILIAL HYPERCHOLESTEROLEMIA. Tsutomu KOBAYASHI ${ }^{1}$, Kimiko KOBAYASHI $^{1}$, Hisako YANAGI ${ }^{1}$, SHIGERU TSUCHIYA ${ }^{2}$, Hideo HAMAGUCHI ${ }^{1}$. ${ }^{1}$ Dept. Med. Genet., Inst. Basic Med. Sci. and ${ }^{2}$ Inst. Comm. Med., Univ. Tsukuba, Tsukuba

The purpose of this research is to identify point mutations or abnormalities in a small region of the LDL receptor gene in FH (familial hypercholesterolemia). Each exon of the LDL receptor gene was amplified by PCR (polymerase chain reaction), and analyzed by SSCP (single strand conformation polymorphism)analysis in each proband of 33 families with FH. As to the exons in which abnormalities were detected by SSCP analysis, their DNA sequences were determined. Thus far two novel mutations that cause FH have been detected. In one family, a frameshift mutation due to one base-pair deletion at 2 nd base of codon 531 was detected in exon 11 . Because of the mutation, a stop codon appeared after 16 codons for abnormal amino acids sequences. In the other family, a complicated mutation was detected in exon 8: nine base-pairs from 2 nd base of codon 351 to $1 \mathrm{st}$ base of codon 354, AGGGTGGCT, were substituted by 6 abnormal base-pairs, CACTGA. It is deduced that 4 amino acids from codon 351 to 354, Glu Gly Gly Tyr, are substituted by 3 amino acids, Ala Leu Asn, by this mutation. To our knowledge, this type of complicated mutation has not been reported at least in the LDL receptor gene.

\section{B 38}

FAMILY STUDIES OF THE CHILDREN WITH HIGH LP(a) LEVELS. Hisako YANAGI ${ }^{1}$, Akiko NAKAGAWA ${ }^{1}$, Takako IANAKA ${ }^{1}$, Shu-ichi KIKUCHI ${ }^{1}$, Yoshimi KOZU ${ }^{1}$, Shigeru ISUCHIYA ${ }^{2}$ and Hidee HAMAGUCHI ${ }^{1}$ ('Dept. Med. Genet., Univ. Tsukuba, Tsukuba;

2Inst. Comm. Med., Univ. Tsukuba, Tsukuba)

The plasma lipoprotein(a) $[L p(a)]$ level is an independent risk factor for coronary heart disease. Individual differences in the molecular size of the apolipoprotein(a) [apo(a)], the important constituent of $L p(a)$, are inversely correlated with plasma $L p(a)$ levels. To examine the familial aggregation of high $L p(a)$ levels and their association with apo(a) phenotypes, we have studied 17 families with high $L p(a)$ levels. The probands were children with $L p(a)$ levels above $30 \mathrm{mg} / \mathrm{dl}$ (90 percentile level) and were screened out from the 178 school-age children. Thus far, we have detected 23 different apo(a) isoforms by gradient SDS/PAGE followed by immunoblotting with a monoclonal apo(a) antibody and are designated A1, A2, B, and $C_{1}$ to $\mathrm{C} 20$ from the lowest to highest molecular weight. All of the probands and 17 family members with $L p(a)$ levels above $30 \mathrm{mg} / \mathrm{dl}$ had smaller isoforms than C8. In contrast, only three of the 16 family members with $L p(a)$ levels below $30 \mathrm{mg} / \mathrm{dl}$ had smaller isoforms than $\mathrm{C} 8$. These differences are significant. Furthermore, 17 of the 19 persons with $L p(a)$ levels above $50 \mathrm{mg} / \mathrm{dl}$ had smaller isoforms than $\mathrm{C5}$. These data suggest the familial aggregation of the persons with high $L p(a)$ levels and their association with the apo(a) phenotypes. 


\section{B 39}

THE GENETIC POLYMORPHISMS OF THE MISSENSE MUTATIONS IN APOLIPOPROTEIN E. Yuka WATANABE ${ }^{1}$, Yasuko YAMANOUCHI, Kimiko KOBAYASHI $^{1}$, Hisake YANAGI ${ }^{1}$, Shigeru TSUCHIYA ${ }^{2}$, Ryunosuke MIYAZAKI ${ }^{3}$, Tadao ARINAMI ${ }^{1}$, and Hideo HAMAGUCHI ${ }^{1}$ ( ${ }^{1}$ Dept. Med. Genet., Inst. Basic Med. Sci., ${ }^{2}$ Inst. Comm. Med., Univ. of Tsukuba, Tsukuba; ${ }^{3}$ Kudanzaka Hospital, Tokyo)

Apolipoprotein(apo)E has three major isoforms, apoE2, apoE3, and apoE4, which are coded for by three common alleles at a single apoE locus. The most common apoE3 is considered to be the wild type, and the other two isoforms have been reported to differ from apoE3 by single amino acid substitutions: apoE2 and apoE4 have missense mutations at codon 158 (CGC $\rightarrow$ TGC, Arg $\rightarrow$ Cys) and codon $112($ TGC $\rightarrow$ CGC, Cys $\rightarrow$ Arg), respectively. To reveal the apoE polymorphism at DNA levels, we have analyzed the apoE2 and apoE4 alleles in unrelated Japanese, using PCR amplification and dot-blot hybridization with allele-specific oligonucleotide probes. The missense mutation of codon 112 (TGC $\rightarrow$ CGC, Cys $\rightarrow$ Arg) has been detected in all 75 apoE4 alleles examined. On the other hand, the missense mutation of codon 158 (CGC $\rightarrow$ TGC, $\mathrm{Arg} \rightarrow \mathrm{Cys}$ ) has been detected in 30 of 34 apoE2 alleles. These results suggest that almost all apoE4 alleles have the codon 112 missense mutation (TGC $\rightarrow$ CGC) and that about $90 \%$ of apoE2 alleles have the codon 158 missense mutation (CGC $\rightarrow$ TGC) in Japanese.

\section{B 40}

GENETIC POLYMORPHISM OF APOLIPOPROTEIN E AND HYPERLIPIDEMIA IN JAPANESE: VII. EFFECTS OF APO E5 \& E7 ON SERUM LIPID LEVELS. Yasuko YAMANOUCHI', Tadao ARINAMI', Shigeru TSUCHIYA ${ }^{2}$, Ryunosuke MIYAZAKI ${ }^{3}$, Hideo HAMAGUCHI'. ('Dep. Hum. Genet., Inst. Basic Med. Sci., ${ }^{2}$ Inst. Comm. Med., Univ. Tsukuba, Tsukuba; ${ }^{3}$ Dep. Med., Kudanzaka Hosptal, Tokyo.)

Frequencies of apo E5 and E7 were examined in Japanese males under 65-year-old, who visited to Kudanzaka Hosp., Tokyo, for their annual medical examinations. The males who were found to have abnormalities of the liver, renal functions and/or diabetes mellitus or who had had a history of surgery involving the digestive system were excluded from the investigation. Apo E phenotypes were determined in 608 males by two-dimensional gel electrophoresis using VLDL-rich fractions. The frequency of individuals with apo E5f (faster than the mobility of apoE3) in SDS/PAGE was $0.9 \%$ (four apo E3/5f and one apo E2/5f). The frequency of individuals with apo E7 was $1.8 \%$ ( nine apoE3/7 and two apo E4/7). They were all normolipidemic. The average effects of the $\varepsilon 5 f$ and $\varepsilon 7$ alleles which were estimated according to the formulas presented by Singand Davignon (1985), were to lower TC and LDL-C, respectively. The average effects of the $\varepsilon 5 \mathrm{f}$ and $\varepsilon 7$ alleles on apo Band apo $\mathrm{E}$ levels were different from those of the $\varepsilon 2$ allele. These data suggest that both the heterozygotes for apo E5f or E7 are not associated with hypercholesterolemia. 


\section{B 41}

DNA POLYMORPHISMS OF THE APOLIPOPROTEIN B $3^{\prime}$ HYPERVARIABLE REGION IN PATIENT WITH HYPERLIPIDEMIA

Tetsuro MIKI $(1,2)$, Emiko MIYAZAKI (2), Yoshiko TABATA (2), Toshio OGIHARA (1), Yuichi KUMAHARA (2), (1) Osaka University Medical School, Osaka and (2) Sakuragaoka Hospitel, Nishinomiya, Japan

We have analyzed the $3^{\prime}$-flanking region of the apolipoprotein $B$ (APOB) gene which contains a hypervariable region comprising a variable number of tandemly repeated short $A+T$ rich sequences. The APOB gene plays an important role in LDL metabolism and is associated with hyperlipidemia. The polymorphic region was amplified by PCR and the products was visualized by ethidium bromide staining after electrophoresis. Each unit of the repeat comprises $14-16 \mathrm{bp}$. The commonest allele contains 35 repeat units and is $660 \mathrm{bp}$ long in 76 healthy control individuals. We have typed alleles from patients with hypercholesterolemia $(n=19$, mean $288.5 \mathrm{mg} / \mathrm{d} 1$ ), hypertriglyceridemia ( $\mathrm{n}=20$, mean $657.0 \mathrm{mg} / \mathrm{d} 1$ ) and hyper LDL cholesterolemia ( $n=15$, mean $209.4 \mathrm{mg} / \mathrm{d} 1$ ).

The distribution of alleles in those patients is not different from that in control population. This result suggests that the $A P O B$ locus does not contribute significantly to serum lipid level.

\section{B 42}

Family studies on hereditary hypercholesterolemia in children. Yae SHIMAKURA ${ }^{1}$, Hisako YANAGI ${ }^{2}$, Kimiko KOBAYASHI ${ }^{2}$, Chiaki HIRANO ${ }^{1}$, Tadao ARINAMI ${ }^{2}$, Shigeru '́suCHIYA ${ }^{3}$, Hitoshi TAKITA' and Hideo HAMAGUCHI ${ }^{2}$ ('Dept. Pediatr., 'Dept. Med. Genet., ${ }^{3}$ Inst. Comm. Med., Univ. Tsukuba)

Two hundred and thirty one children were diagnosed to be hypercholesterolemia(HC) from school survey of 2,822 children and family studies of these hypercholesterolemic children were performed. Eighteen families with hereditary hypercholesterolemia were detected. Based on clinical feature, we diagnosed three families as familial hypercholesterolemia, and five families as familial combined hyper1 ipidemia(FCHL). The other ten families were hereditary moderate hypercholesterolemia and the hyper 7ipidemia was type IIa. The relationship between hyper Tipidemia and RFLP haprotypes in the apoAI-CIII gene cluster was examined in four FCHL fami 1ies: hyper 7 ipidemia and the RFLP haprotype were not co-segregated in one FCHL family and the relationship was not informative in two families. In addition, the relationship between HC and RFLP haprotypes in the LDL receptor gene were analyzed in four families with hereditary moderate hypercholesterolemia: HC and the RFLP haprotype was not co-segregated in al1 four families. Familial defective apoB-100 were not detected in fifteen families so far examined by using PCR and ASO probe method. These data suggest that these moderate hereditary hypercholeaterolemia in childhood are caused by unknown genet ic factors. 


\title{
B 43
}

MOLECULER CLONING OF CDNA FOR HUMAN MITOCHONDRIAL SHORT CHAIN ENOYL-COA HYDRATASE. Masaki KANAZAWA, Hi roki ABE. Akira OHTAKE, Hi roo NIIMI (Dept. of Pediatr. . Chiba Univ. . Chiba), Yoshinori SATOH (Dept. of Pediatr.. Shimoshizu Nat1. Hosp. and Sanatorium, Yotsukaido, Chiba), Iakashi HASHIMOTO (Dept. of Biochemistry, Shinshu Univ. Sch of Med., Matsumoto, Nagano)

\begin{abstract}
Mitochondrial short chain enoy 1-CoA hydratase (SCEH) (EC 4.2.1.17) catalyze the second step of mitochondrial fatty acid $\beta$-oxidation system. To facilitate investigation of the enzyme and gene structure and to elucidate the nature of the mutation in inherited disorders of fatty acid oxidation, we i solated cDNA clones for human SCEH. Oligo $d(T)$ primed and randam primer human liver cDNA libraries in $\lambda$ gt 11 were screened using isolated rat SCEH cDNA as a probe. some positive clones of the enzyme were subcloned into plasmid vecters, which were subjected to nucleotide sequencing. Three of 38 positive clones for human SCEH, which contained an overlapping cDNA sequence of 1.3 kilobase-pairs, almost covered the human SCEH mRNA sequence with an open reading frame encoding a polypeptide of 290 amino acid residues (predicted Mr, 31339). The predicted amino acid sequence of human \$CEH is $84 \%$ identical with that of rat SCEH. RNA gel blot analysis of human various tissues showed a single mRNA of 1.6 kilobases for SCEH.
\end{abstract}

\section{B 44}

遗伝性メトヘモグロビン血症における組織特異的発現異常の分子暀構

勝部孝則、坂本憲広、小林靖、関律子、服巻保幸 (九大遗伝情報). MOLECULAR ANALYSIS OF HEREDITARY METHEMOGLOBINEMIA, TYPES I AND III. T. Katsube, N. Sakamoto, Y. Kobayashi, R. Seki, Y. Fukumaki (Research Laboratory for Genetic Information, Kyushu University, Fukuoka)

遭伝性メトヘモグロビン血症はNADHcytochromeb5還元䤃素(b5R)の異常により起こる劣性の遺 伝性疾患である。この酵素は種々の組織に存在するにもかかわらず、本疾患は赤血球のみで久 損が見られる型、全身の組織で損がある型、さらに血球のみで異常が見られる型とに 分けられ、臨床症状としては仍び而型ではチアノーゼのみ、そして型ではこれに加え精神 発育遅延が見られる。我々はすでに型につき解析を行ないエクンン内に変異を報告している。 今回は組織特異的発現異常の分子レベルでの機構を明らかにするためにIおよび而の木モ接 合体のb5R遺伝子の構造をPCR法を用いて解析し以下の結果を得た。1) I型ではコドン57にG-A 変異(Arg-Gln)を見い出し、ホモ接合体であることをPCR産物のMspl切断による解析により確認 した。ASOを用いたドットブロットを正常日本人の88アレルを対象に行い、変異がコモンな多 型でないことを確認した。2) II型ではコドン148のT-C変異(Leu-Pro)が見られた。同様にMsplを 用いた解析によりホモ接合体であることを確認した。また正常92アレル中にこの変異は検出さ れなかった。病因としては現在、変異酵素の安定性か葴器每に異なる可能性を考えている。 


\section{B 45}

MOLECULAR ANALYSIS OF COMPOUND HETEROZYGOUS $\beta$-THALASSEMIA PATIENT AND HER FAMILY . Hitoshi NAKASHIMA, Takashi IMAMURA ( Dpt.Hum.Genet., National Institute of Genetics, Mishima), Yutaka CHIFU (First Dpt.Int.Med.,Kyushu Univ.,Fukuoka)

A very rare compound heterozygous $\beta$-thalassemia female patient ( $\mathrm{HbA} \mathrm{O}, \mathrm{HbF} 98.4 \%, \mathrm{HbA}_{2} 1.4 \%$ ) was found. Both parents and younger brother were heterozygous $\beta$-thalassemia. Molecular analysis demonstrated that maternal and paternal mutation are $C \rightarrow T$ transition at IVS-2 position 654 and $G \rightarrow A$ transition at IVS-2 position 1 , respectively. The former mutation is shown in the $\beta$-globin gene framework (FR1) on the background of haplotype IX, and the latter mutation is in the FRla gene on the novel haplotype XI. The recurrent observation of these mutations on various gene and chromosal backgrounds is explained by the genetic interplay of gene migration and multiple origin of the same mutation in the world populations.

\section{B 46}

STUDIES ON ABO AND E BLOOD GROUP SYSTEMS RELATED TO THE REACTIVITY OF HUMAN RED CELLS WITH ANTI-H AGGLUTININS

Ken Furukawa, Tamiko Nakajima and Takasumi Matsuki (Department of Legal Medicine, Gunma University School of Medicine, Maebashi)

Blood groups $A, B$ and $A B$ are classified into two groups, $E$ and $e$ which red cells were agglutinated stronly and werkly with type II eel serum respectively (Sugishita, 1935). It has been considered that the E system was not related to $A$ and $B$ genotypes of red cells because of $E$ and $e$ does not correspond to heterozygote and homozygote of groups $A$ and $B$. We have tested the agglutinability of $\underline{A_{1} 0}$ and $\underline{A_{1} A_{1}}$ red cells with numerous anti-H reagents, normal and immunnized human and animal sera, and the extracts of certain plant seeds. Most of the reagents except chicken anti-H agglutinated $A_{1} 0$ cells stronger than $A_{1} A_{1}$ cells. Difference of the agglutinability between $\underline{A_{1} D}$ and $\underline{A_{1} A_{1}}$ was remarkable in eel sera by saline agglutination. The reactivities of $\underline{B} 0$ and $\underline{B B}$ red cells with the anti-H reagents were the same strength as that of $\underline{A_{1} 0}$ and $\underline{A_{1} A_{1}}$. Therefor, $\underline{A_{1} O}$ and $\underline{B} \underline{0}$ tested were correspond to $E$, and $\underline{A_{1} A_{1}}$ and $\underline{B}$ belonged to $\mathrm{e}$. We found that some eel sera contained irregular agglutinins which are demonstrated by the reaction of red cells of Bombay phenotype. It is important that eel serum only containd Sugishita's type II high titer anti-H agglutinin should be selected for A and B genotype examinations. 


\section{B 47}

CHANGE FROM $H P^{* 2}$ TO $H P^{*} 1$ BY HOMOLOGOUS RECOMBINATION DETECTED IN NORMAL HUMAN SOMATIC AND SPERM CELLS. Jun-ichi ASAKAWA ${ }^{1}$, Nori NAKAMURA ${ }^{2}$, Mieko KODAIRA ${ }^{1}$, Chiyoko SATOH ${ }^{1}$ ( ${ }^{1}$ Dept. of Genetics, RERF, Hiroshima; ${ }^{2}$ Dept. of Radiobiology, RERF, Hiroshima)

Among a total of 23,326 Japanese examined for plasma haptoglobin (HP) by starch gel electrophoresis, two individuals mosaic for HP 2-2 and HP 1-2 cells were found. Because $H P^{*} 2$ is made of partial duplication of $H P^{*} 1$, it was suspected that the change from $H P^{*} 2$ to $H P^{*} I$ was caused by intra-locus somatic recombination and consequent deletion of the duplicated portion. A PCR assay was developed to detect rare $H P^{*} 1$ allele among DNA from HP 2 homozygous individuals. $20 \mu \mathrm{g}$ of genomic DNAs, double digested with BamHI/HindIII, were electrophoresed. Gels, supposed to contain $H P^{*} I$ allele $(2.5 \mathrm{~kb})$, separated from normal $H P^{*} 2$ allele $(4.2 \mathrm{~kb})$, were cut out and divided into 60 PCR tubes and were PCR amplified with $H P$ gene specific primers. The frequencies of cells bearing $H P^{*} 1$ allele were about $1 \times 10^{-6} / \mathrm{cell}$ for both sperm and white blood cells. Treatments of EB virus transformed B-cells from a normal HP 2-2 donor with Mitomycin C or X-rays showed a dose dependent increase of the frequency.

\section{B 48}

MODIFICATION OF THE BANDING TECHNIQUE FOR FLUORESCENCE in situ HYBRIDIZATION. Osamu MIKAMI, Tomoko HASHIMOTO, Atsuko OGAWA, Yoshihiro YAMAMOTO, Hiromi SAKAMOTO and Jun-ichi FURUYAMA (Dept. Genet., Hyogo Col. Med., Nishinomiya)

Fluorescence in situ hybridization (FISH) is a very useful means in mapping on chromosomes at genes or DNA fragments. By this technique, lots of genes have been mapped up to the present. But, in many examples, chromosomes were deformed and banding pattern of chromosomes became indistinct by heat denaturation of chromosomal DNA, and mapping was liable to lack accuracy.

Chromosomal DNA of BrdU-non-treated chromosome specimen was heatdenatured in $2 \%(\mathrm{w} / \mathrm{v})$ tannic acid and $70 \%(\mathrm{v} / \mathrm{v})$ formamide in $2 \times$ SSC solution at $70^{\circ} \mathrm{C}$ for $5 \mathrm{~min}$, and FISH was done using the denatured chromosome specimen. Heat denaturation in a solution including tannic acid made the degree of deformity of chromosomes far smaller than by heat denaturation in the solution without tannic acid. But tannic acid did not inhibit the FISH using biotin labeled DYZ3 and D17Z1 satellite DNA probes. As a result, the stable chromosome banding by 4'-6-diamidino-2-phenyl-indole (DAPI: $G$ banding pattern), chromomycin $A_{3}$-distamycin A ( $R$ banding pattern) and distamycin A-DAPI ( $C$ banding pattern) became able to be carried out. 
B 49

CHROMOSOME BAND-SPECIFIC PAINTING: CHROMOSOME IN SITU HYBRIDIZATION USING PCR PRODUCTS FROM A MICRODISSECTED CHROMOSOME BAND AS A PROBE POOL. Kohichiro YOSHIURA, Han-Xiang DENG, Roeland W. DIRKS, Tohru OHTA, Takaya TOHMA, Naoki HARADA, Tetsuya HIROTA, Kazuhiro TSUKAMOTO, Yoshihiro JINNO, and Norio NIIKAWA (Dept. Hum. Genet., Nagasaki Univ. Sch. Med., Nagasaki), Yoshimitsu FUKUSHIMA (Div. Med. Genet., Saitama Child. Hosp)

We describe a novel, chromosome band-specific painting method that involves (1)microdissection of chromosome, chromosomal region or band, (2)amplification of variety of chromosome/region/band-specific DNA fragments with polymerase chain reaction (PCR), and (3)chromosome in situ suppression hybridization (CISS) with the direct use of the PCR products as a probe pool. With this method, it was possible to paint an entire $X$ or $Y$ chromosome, a distal one-fourth of $2 q$, and on $7 y$ a band at $8 \mathrm{q} 24.1$, to identify the origin of a minute marker chromosome in a mentally retarded patient, to detect an $X ; Y$ translocation in another patient, and to identify one human chromosome 2 in a humanmouse hybrid cell-line. This method allows to identify not only structural chromosome abnormalities at the band level but also the origin of cytogenetically unidentifiable marker chromosomes. It is also useful for studies of evolutional cytogenetics.

\section{B 50}

HIGH-RESOLUTION CYTOGENETIC MAPS OF COSMID DNA MARKERS FOR HUMAN CHROMOSOME 3 AND 11. Tada-aki HORI, Ei-ichi TAKAHASHI (Div. Genet., Nat1. Inst. Radiol. Sci., Chiba), Takashi TOKINO, Kazuhiro YAMAKAWA, and Yusuke NAKAMURA (Div. Biochem., Cancer Inst., Tokyo)

The construction of high-resolution cytogenetic map is one of essential steps for the identification of genes responsible for genetic diseases, as well as for the initial step of Human Genome Project which intends to construct physical contig maps and to determine the complete sequence of human DNA. Chromosomal localization of genes or DNA markers can be determine by a technique of fluorescence in situ hybridization (FISH). By applying the direct FISH system we developed, we have constructed high-resolution cytogenetic maps of human chromosome 3 with 280 cosmid clones (including 125 RFLPs) and chromosome 11 with 168 cosmid clones (90 RFLPs). The cosmid markers for chromosome 3 and 11 are spaced with averaged distances of $760 \mathrm{~Kb}$ and $860 \mathrm{~Kb}$, respectively, although these markers are localized to R-positive bands. These maps, inconjunction with genetic linkage analysis with mapped RFLP markers, will contribute to the identification of genes of interest on chromosome 3 and 11 , and also provides many useful landmarks for the construction of physical contig maps with cosmid or YAC clones. 


\section{B 51}

MAPPING OF CHROMOSOME 11 COSMID DNA WITH TWO-COLOR FGUORESCENT in situ HYBRIDIZATION: Hitoshi NAKAGAWA ${ }^{1}$, Johij INAZAWA ${ }^{2}$, Shinichi MISAWA ${ }^{1}$ Teruyuki TAKASHIMA ${ }^{1}$ Shinj 1 TANAKA , Shjgeo HORIIKE Shouhe i ' YOKOTA', Masafumi TANIWAKI', Kei KASHIMA ' Tatsuo ABE ${ }^{2}$, Takeshi AZUMA ${ }^{3}$ ( 13 rd Dept. Med., Zept. Hygiene, ${ }^{3}$ Dept. Pubric Health, Kyoto Pref. Univ. of Med., Kyoto)

Four DNA probes from chromosome 11 specific cosmid library were mapped on human metaphase chromosomes with fluorescent in situ hybridization (FISH). Cosmid clones, PGAC1, PGA7A1, PGA8F1, and PYGMCL15 were labeled with biotin-16-dUTP or digoxigenin-11-dUTP with nick translation. FISH was done according to the method of Laurence et al. (1988) with modifications. Hybridization signals were detected with FITC avidin and anti-digoxygenin-rhodamine under a fluorescent microscope. PGAC1 and PYGMCL 15 were both mapped on 11q13.1. Two-color FISH with a dual band filter set (OMEGA OPTICAL, INC.) revealed PGAC1 proximal of PYGMCL15 on the same region, 11q13.1. PGA7A1 and PGA8F1 were mapped to 11q23.3 and 11q24, respectively. These 2 probes were translocated to $9 p+$ with $t(9 ; 11)$, which was found in a patient with acute monocytic leukemia. Thus, the order, cen-PGAC1-PYGMCL 15-t $(9 ; 11)(p 22 ; q 23)-$ PGA7A1-PGA8F1-te1, was determined.

\section{B 52}

CHROMOSOMAL ASSIGNMENT OF Zn- $\alpha$-GLYCOPROTEIN (Zna2gp) GENE TO 7q22 BY CHROMOSOME IN SITU SUPPRESSION ${ }^{2}$ (CISS) HYBRIDIZATION. Hisao UEYAMA, DENG Han-Xiang, *Norio NIIKAWA, and Iwao OHKUBO (Dept. Med. Biochem., Shiga Univ. Med. Sci., Otsu, and *Nagasaki Univ., Nagasaki)

$\mathrm{Zn}-\alpha_{2}-\mathrm{glycoprotein}$ (Zna2gp) is a glycoprotein with a molecular weight of $38,000-40,000$ and is found in blood plasma. Zna2gp is related to antigens of MHC complex with respect to amino acid sequence and domain structure. Therefore it is of interest to examine whether its gene is linked to those for MHC antigens (6p) on the human chromosome. We have isolated its cDNA and gene clones of human source, and mapped the gene to human chromosome 7 by using a panel of rodent-human somatic cell hybrids. In this communication, we determined the gene locus (ZA2G) by chromosome in situ suppression hybridization method. The probe DNA, which is the $14.3 \mathrm{~kb}$ insert of the gene clone, ZG12, was labeled with biotin-16-dUTP, and human genomic DNA (100 times excess) was included in the hybridization mixture. The signal was detected with FITC-avidin under fluorescence microscopy. The Zna2gp gene was assigned to chromosome 7 at the region of $q 22$. 


\section{B 53}

NON-RADTOACTIVE IN SITU HYBRIDLZATTON (NISH) SIUUY WITH CHROMOSOME-SPECIFTC ALPHA SATELLTTE DNA PROBES (D18Z1, D21Z1/D13Z1) OF TNTERPHASE SIGNALS FOR PRENATAL DTAGNOSIS.

Mizuki KATO, Haruhiko SAGO, Kazuso IINUMA (Clin. Dysmorph. Lab., Nat. Child. Med. Res. Center, Tokyo)

As a supporting technique to conventional chromosome studies for prenatal diagnosis, non-radioactive in situ hybridization (NISH) using human chromosomespecific centromeric alpha satellite DNA probes (D18Z1 and D21Z1/D13D1) was carried out on the prepartions of human diploid lymphocytes, amniocytes and chorionic villous samples (CVS). For the study of detecting chromosome aberrations, lymphocytes with either trisony 21 or trisony 13 were analysed with the same probe. In the diploid interphase nuclei of lymphocytes, amniocytes and CVS , the frequencies of cells with two hybridized signals with D18Z1 were $93.0 \%, 91.5 \%$ and $88.5 \%$, respectively, and when D21Z1/D13Z1 probe was used, those with four signals were $84.6 \%, 79.3 \%$ and $71.5 \%$, respectively. The frequency of false positive signals was, among all, less than $2 \%$. When cells with either trisony 21 or trisomy 13 were analysed with D21Z1/Di3Z1 probe, the frequencies of interphase nuclei with 5 signals were $43.8 \%$ and $52.5 \%$, respectively, while those with 4 signals were $29.0 \%$ and $28.6 \%$, respectively. From these signal appearance patterns, it would be safe to conclude that NISH can be used as a reliable laboratory aid for prenatal diagnosis of chromosome aberrations.

\section{B 54}

PHYSICAL ORDERING FOR CTSE AND REN ON CHROMOSOME 1 USING TWO-COLOR FISH.

Johji INAZANA, Kiyoshi INOUE, Takeshi ARIYAMA, Tatsuo ABE (Dept. Hygiene), Hitoshi NARAGAWA, Shinichi MISAWA (Dept. Med.) and Takeshi AZUMA (Dept. Prevent. Med., Kyoto Pref. Univ. Med.)

Cateps in E (CTSE) is an enzyme that is found in highest concentration in the surface of epithelial mucus-producing cells of the stomach. Renin (REN) is a proteolytic enzyme produced and stored in the granular juxtaglomerular kidney cells, which plays an inportant role in the control of blood presure and electrolyte balance. Both CTSE and REN belong to aspartyl protease family, and were reported to be syntenic to the long arm of chromosome 1 ; CTSE at $1 \mathrm{q} 31$ (HGM 10.5) and REN at $1 \mathrm{q} 32$ or $1 \mathrm{q} 42$ (HGM 10). We per formed FISH in order to identify presize localizations of CTSE and REN, and determined the physical order of CTSE and REN on the long arm of chromosome 1 using two-color FISH. Our results showed that both CTSE andREN are localized at 1q32, and the $1 \mathrm{i}-$ near order is cen-REN-CTSE-tel. 


\section{B 55}

CONSTRUCTION OF A DNA LIBRARY SPECIFIC FOR A CHROMOSOME REGION 8q23.3q24.1 BY MICRODISSECTION. Tetsuya HIROTA, Kazuhiro TSUKAMOTO, HanXiang DENG, Naoki HARADA, Kohichiro YOSHIURA, Tohru OHTA, Takaya TOHMA, Yoshihiro JINNO (Dept. Hum. Genet., Nagasaki Univ. Sch. Med., Nagasaki), Mitsuo OSHIMURA (Dept. Cell Engin., Tottori Univ.), Yoshifumi YAMAMOTO (Dept. Pediatr. Tokyo Police Hosp.), Yoshimitsu

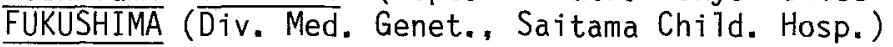

A DNA library was constructed by microdissection of a chromosome region 8q23.3-q24.1. subsequent universal amplification of DNA with a primer-linker PCR method and by cloning into pUC19. The PCR product was assigned to the region by chromosome in situ suppression hybridization (CISS). A total of 35,000 recombinants were obtained. Sixty pUC-clones were selected and underwent Southern analysis on hybrid cell panels with or without human chromosomes 8 . Twelve $(20.0 \%)$ of the 60 clones were unique sequences, and 9 of the 12 underwent deletion analysis with Southern hybridization in the genomic DNA of a patient with tricho-rhino-phalangeal syndrome type $I$ and in that of the other patient with Langer-Giedion syndrome, both associated with an interstitial deletion at 8g23.3-q24.12. Five of the 9 clones tested showed a one-copy density in both patients. By the second screening of a genomic DNA library constructed in the phage also showed a one-copy density in the two patients.

\section{B 56}

A DNA LIBRARY SPECIFIC FOR 2q33-qter AND A $2 q 35$ PHAGE-CLONE OBTAINED BY CHROMOSOME MICRODISSECTION. Kazuhiro TSUKAMOTO, Han-Xiang DENG, Kohichiro YOSHIURA, Tohru OHTA, Tetsuya HIROTA, Norio NIIKAWA; Yosihiro JINNO (Dept. Hum. Genet., Nagasaki Univ. Sch. Med." Nagasaki), Mistuo OSHIMURA (Dept. Cel1 Engin., Tottori Univ.), Satoshi ISHIKIRIYAMA (Div. Med. Genet., Chiba Child. Hosp.)

We constructed a DNA library specific for 2q33-qter by microdissection of the chromosomal region. Of a total of 50,000 pUC19 recombinants obtained, 88 clones with the mean insert size of $491 \mathrm{bp}$. were selected, and they underwent Southern analysis on hybrid cell panels with or without human chromosome 2. Of the 88 clones, 15 (17.0 \%) were unique sequences, 12 contained both unique and repetitive sequences, 34 were composed of repetitive sequences, and the remaining 27 were the sequences without any hybridization signals to the human DNA. By the second screening of a phage library, 8 clones were obtained. of the 8 clones, 4 were identical and 2 each of the other 4 were overlapping sequences. With chromosome florescence in situ hybridization, the 4 identical sequences were mapped at $2 q 33.3$, and 2 overlapping clones at $2 q 35$. These clones are useful for molecular analys is of Waardenburg syndrome type I. 
B 57

DETECTION OF CRYPTIC TRANSLOCATIONS IN MILLER-DIEKER SYNDROME (MDS) BY FLUORESCENCE IN SITU HYBRIDIZATION. Akira KUWANO, S. A. LEDBETTER, D. H. LEDBETTER (Institute for Molecular Genetics, Baylor College of Medicine, Houston, TX, USA)

Miller-Dieker syndrome is a rare malformation syndrome manifested by type I liss-encephaly and characteristic facies. Fluorescence in situ hybridization using cosmids from $17 \mathrm{p} 13.3$ was performed in two families with MDS.

Case 1. Case 1 involved an MDS patient with der(17)(p+). The mother had the same der(17), but G-banding analysis failed to reveal the reciprocal product. In situ hybridization showed that the mother had two signals of cosmid, one on the normal 17 and the other on 3qter, indicating $3 \mathrm{q} ; 17 \mathrm{p}$ translocation.

Case 2. Case 2 involved an MDS patient with an apparently normal karyotype. Because a large paternal DNA deletion was found, the hypothesis was entertained that the patient represented an unbalanced cryptic translocation involving two G-negative telomeres. In situ studies of her father and normal brother showed an $8 \mathrm{q} ; 17 \mathrm{p}$ translocation.

These results dramatically changed the recurrence risk for this family from a minimal risk for a de novo deletion to a high risk for translocation carriers.

\section{B 58}

A CASE WITH A DELETION OF THE SHORT ARM OF CHROMOSOME 3 Masami ASAI, Yasuhiko ITO, Toshiyuki IGUCHI, Jin ITO, Noboru Okada (Pediat, Yokkaichi Municipal Hospital, Mie) Hidetsune OISHI(Gen, Insti, Aichi Prefectual Colony, Aichi)

The proband was a boy, the first born of healthy non-consanguineous parents when the mother was 19 and the father was 36 years of age. The delivary was spontenous in the cephalic position at the 40 th week of gestation. The Birth weight was $1,950 \mathrm{~g}$, length $42 \mathrm{~cm}$, and head circumfer ence $30 \mathrm{~cm}$. Because of a small-for-dates infant, he was transferred to us. The craniofacial appearance was dysmorphic with a high and broard forehead, flat occiput, ptosis, narrow palpebral fissures, dysplastic and low-set ears, short neck, and micrognathia. Anal atresia and a deep sacral dimple were noted. The forth toes placed on the high position. The cytogenetic finding was $46, \mathrm{XY}$, del $(3)(\mathrm{p} 25.3 \rightarrow \mathrm{pter})$. The karyo types of parents were normal. At age 10 months, his body weight was $4020 \mathrm{~g}(-5.9 \mathrm{SD})$ and length $55 \mathrm{~cm}(-7.6 \mathrm{SD})$ and he was incapable of rolling-over and sitting. Deletions of the short arm of chromosomo 3 are relatively rare. Most cases involve the distal segment (3p 25). To our knowledge, 16 cases were reported previously. The clinical features of this proband are compared with them. 


\section{B 59}

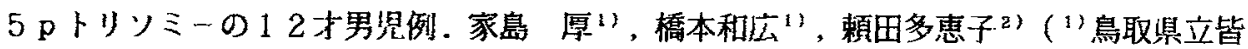
生小児療育センター小児科, ${ }^{2}$ 鳥取大学医学部脳研小児科）. A 12-year-old boy with pure duplication 5p. Atsushi Ieshima ${ }^{1}$, Kazuhiro Hashimoto" ${ }^{1}$ and Tieko Yorita ${ }^{21}$ ("Div. of Child Neurology, Tottori Prefectural Kaike Rehabilitation Center for Disabled Children, Yonago; 2)Div. of Child Neurology, Tottori University School of Medicine, Yonago)

pure $5 \mathrm{p}$ trisomy の本邦第 1 例（12才男児例）を報告した。

症例は，妊娠中異常なく，38週2320gで仮死出生。小頻症，口蓋裂，耳介低位，番根部

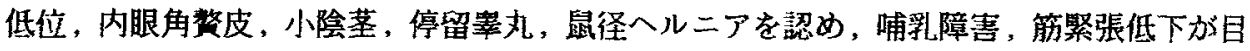
立った。泣き声が猫泣き症様に心ん高く，2才よりケイレン発作発症。尿路感染症を繰り 返し, IVPで, 重複腎孟, VURと診断。4 才時, 染色体検相て $46, X Y, \operatorname{dup}(5 \mathrm{p})$ (p15.1 $\rightarrow$ pter.) と診断。成長障害, 精神運動発達遅滞（ $\mathrm{DQ}=18$ ）を認めた。

$5 \mathrm{p}$ トリソミ一は, 大奇形の合併が少なく，生命子後は良好であった。 pure trisomyで

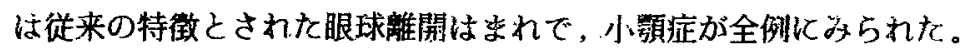

\section{B 60}

7q- Mosaicism in Identical Twins. Hiroko Tsukamoto, Masako Taniike, Koji Inui, Shintaro Okada (Dept. Pediatr., Osaka Univ., Osaka) Masahiko Hori, Kiyohumi Kaniyama (Teijin Bio Lab) and Kiyoomi Sumi (Osaka Koseinenkin Hosp.)

Male identical twins with 7q- mosaicism presented with quite different phenotypes. The first child (twin1) was born (weight 2540g) without any anomalies and showed normal physical and psychomotor development. The second child (twin2) was born (weight 2500g) and showed many minor anomalies including microcephaly, auricular abnormalities, mongoloid slants, hyperterolism and cryptochidism. His growth and psychomotordevelopment was severely retarded. Chromosomal analysis : lymphocytes

skin fibroblasts

\begin{tabular}{|c|c|c|}
\hline & $46, X Y$ & $46, X Y, \operatorname{del}(7)(q 32-a \operatorname{ter})$ \\
\hline twi & $30 \%$ & $70 \%$ \\
\hline wi & $30 \%$ & $70 \%$ \\
\hline & $100 \%$ & $0 \%$ \\
\hline & $0 \%$ & $100 \%$ \\
\hline
\end{tabular}

The karyotypes of both parents were normal. Fingerprinting of DNA from whole blood showed the same pattern in both twins but that of DNA from cultured skin fibroblasts showed a different pattern corresponding to the deletion of chromosomal analysis. We diagnosed this twins as identical one. Erronous mitosis probably occured around twinning. Mosaicism found in blood might be produced by twin-to-twin blood transfusion. 


\section{B 61}

A CASE OF DIRECT TANDEM DUPLICATION OF THE SHORT ARM OF CHROMOSOME 8. Masataka FUJIWARA, Hotaka KAMASAKI, Yasuyuki MORITA, Makoto KAMADA (Dept. Pediatr., Hakodate Municipal Hospital, Hakodate)

We report on a case of interstitial tandem duplication of short arm of chromosome 8 . The patient is a 1-year-old female infant with mental retardation and mild generalized muscle hypotonia. Several physical abnormalities were recorded; deformity of head, slightly low-set ears, tapering of fingers, hypoplasia of nails. High resolution banding method revealed her karyotype was de novo $46, X X$, dir dup(8) (p21.3 $\rightarrow$ p23.1).

At least 37 patients of trisomy $8 \mathrm{p}$ have been reported in 25 previous reports, but the most of them were derived from parental translocation. 13 cases of tandem duplication including our case have been reported but direct tandem duplication is rare. We report mainly on the clinical feature of the patient.

\section{B 62}

INV (9) CHROMOSOME: SEX DIFFERENCE AND CLINICAL SIGNIFICANCE.

Kiyomi YAMADA (Div. Genet., Clin. Res. Inst., National Medical Center, Tokyo)

Population incidence of an inv(9) chromosome was studied using a $\mathrm{C}$-banding (DA-DAPI stain) in 4,100 individuals of a normal control and 5 patient groups. All of the inv(9) were a total inversion of the $\mathrm{C}$-band material.

The inv(9) incidence was $1.65 \%$ in the normal control group ( $n=$ $1,513)$, and $1.49 \%$ in the Down syndrome group $(n=1,210)$. Female inv(9) carriers were 1.7 times higher in the frequencies of the above two groups, and the sex difference was statistically significant.

Furthermore, about 2 times excess of inv(9) carriers was observed in the habitual abortion couple group $(n=514)$ and the spontaneous abortus group $(n=170)$, both having normal karyotypes. The existence of a genetic effect of inv(9) on human reproduction was revealed. The risk of inv(9) carriers for abortions was estimated to be 3.8 times higher in husbands and 1.3 times higher in wives than non-carriers, showing more susceptibility of males to genetic impairment related to the inv(9) in terms of reproductive anomalies. 


\section{B 63}

CLINICAL EVALUATION ABOUT' PERICENTRIC INVERSION OF CHROMOSOME \#9. Shigeki UEHARA, Toshifumi TAKABAYASHI, Noriko MIYASHITA, Yumiyo KURAHAYASHI, Yukiko AKAI, Kunihiro OKAMURA and Akira YAJIMA (Dept. Obstet. Gynecol., Tohoku Univ. Sch. Med., Sendai)

In order to evaluate the relation between pericentric inversion of chromosome 9 (inv(9)) and clinical problems, the incidence of inv(9) was investigated based on chromosomal analyses in fetuses and in infertile couples. The incidence of inv(9) in fetuses with parents having an offspring who suffered from Down's syndrome, that in the fetuses in which abnormal findings were detected in prenatal ultrasound examination and that in the infertile couples were higher ( 2 to 3-fold) than the basic incidence obtained in fetuses karyotyped by reason of advanced maternal age. In the infertile couples, inv(9) carriers were found much more frequently among husbands than wives. Furthermore, infertile couples with an inv(9) carrier showed a higher incidence of intrauterine fetal death after the second trimester, compared with infertile couples having other reasons. Therefore, it is indicated that the possibility of abnormality induced by inv(9) should not be neglected by clinicians in their clinical work.

\section{B 64}

A CASE WITH A CHROMOSOME 12q-: 46,XY, del(12) (pter-q24.31:). Satoshi ISHIKIRIYAMA, Kohzoh MATSUO, Tadashi FUJIWARA, Mika UCHISHIBA, Hiroyuki AOTSUKA, Koichiro NIWA (Chiba Children's Hospital, Chiba) and Yoshimitsu FUKUSHIMA (Saitama Children's Medical Center, Hasuda)

$12 \mathrm{q}^{-}$is a rare chromosomal aberration.

A male baby was born to a 36-year-old father and a 30-year-old mother after an uneventful, 38-week pregnancy except for IUGR. His weight was $1706 \mathrm{~g}$ at birth. He suffered both from esophageal atresia (Gross type C) and from Fallot's tertralogy. He died of sepsis when he was 32 days old. He had an enlarged fontanel, downward slanted palpebral fissures, blephalophimosis, micrognathia, low set ears, a short neck, widely spaced nipples, hypospadias, small hands and clinodactyly of the Vth finger.

Chromosome analysis with GTG-banding revealed a deletion in a long arm of a chromosome 12. A chromosomal break occured at q24.31. His karyotype was 46,XY, del(12) (pter $\rightarrow \mathrm{q} 24.31:$ ). The karyotypes of his parents were quite normal. We established a cell-line from his peripheral lymphocytes transformed by EB virus.

These clinical findings were quite different from those in a 6year-old girl with del(12) (q24.3) previously reported in Japan. Some of the differences might be ascribed to "genomic imprinting". 


\section{B 65}

FAMILIAL OCCURRANCE OF RING CHROMOSOME 15. Ikuko KONDO (Dept. of Hum. Ecol. and Genet., Univ. of the Ryukyus, Okinawa), Yumi HORIGOME(Dept. of Pediatr., Hidachi Taga Hosp., Ibaraki) and Katsuko KUWAJIMA (Dept. of Pediatr., Ibaraki Pref. Handicap Child. Center, Ibaraki)

We present a family with the ring 15 chromosome, $r(15)$ syndrome, a two-year-old infant and his mother. Both had common clinical manifestations in previously reported cases with $r(15)$, including severe short stature, microcephaly, trianglar face, and mild mental retardation. The family also had a normal son. Although males with $r(15)$ syndrome usually seem to be infertile, female $r(15)$ patients are likely to be fertile and their reproductivity may be influenced by severe growth retardation.

\section{B 66}

CHARACTERIZATION OF INACTIVE CENTROMERES OF THE PSEUDODICENTRIC CHROMOSOME 18. Tatsuro IKEUCHI ${ }^{1}$, Kohtaro YAMAMOTO ${ }^{2}$, Katsuyuk i HASHIMOTO ${ }^{3}$, Ei-ichi TAKAHASHI ${ }^{4}$, Tada-aki HORI $^{4}$ ('Div. Cytogenet., ${ }^{2}$ Div. Virol. Immunol., Med. Res. Inst., Tokyo Med. Dent. Univ., ${ }^{3}$ Gene Repository, Nat1. Inst. Health, Tokyo, ${ }^{4}$ Div. Genet., Natl. Inst. Radiol. Sci., Chiba)

Pseudodicentric chromosomes possess two centromeres, but only one is active showing a centromeric constriction. In order to know the mechanism of centromere inactivation, we have studied the cytogenetic characteristics of inactive centromeres of a pseudodicentric chromosome 18, psu dic(18) (qter $\rightarrow$ cen $\rightarrow$ p11. $32:$ : p11.32 $\rightarrow$ qter), which was found in a newborn girl with 18-trisomy syndrome. Both peripheral blood cultures and lymphoblastoid cell lines were used. The dic(18) chromosomes showed a single C-band at the active centromere and two separated $\mathrm{C}$-positive regions at the second centromeres of sister chromatids. The $\mathrm{Cd}-$ staining was negative on the inactive centromeres. Fluorescent in situ hybridization (FISH) using a \#18-specific alpha satellite DNA probe, L1.84 (D18Z1), revealed that the fluorescent signals were, like the C-bands, separately detected on the inactive centromeric regions of two chromatids. These findings indicate that the inactive centromere retains highly repetitive alpha satellite DNA sequencies, but lacks a certain centromere-associated protein(s). 


\section{B 67}

A CASE OF MULTIPLE RECURRENCE OF TRISOMY 21

Noriko FUJITA, Yuko SHIRAHATA, Mizuho TAKATA, Yukari YANAGI*, Hiroshi NAKAJIMA**, Shozo TAMURA(Dept. Gyne. \& Obst., Keio Univ., Keio Heal th Couns. Center ${ }^{*}$, Nakajima Clinic ${ }^{* *}$ )

27-year-old pregnant woman visited to our hospital for amniocentesis. Her first child was trisomy 21. She remarried after, but her second child was also trisomy 21 who died at 11 months due to his heart anomaly. She had no other relatives suffering from trisomy 21. Amniocentesis at 17-weeks gestation revealed that fetal karyotype was $47, \mathrm{XX},+21$. The reason of the multiple recurrence proved to be chromosomal mosaicism including $47, \mathrm{XX},+21$ ( $0 \%$ in blood, $4-10 \%$ in skin fibroblast). Though we couldn't carry out the ovarian biopsy, the percetage of $47, \mathrm{XX},+21$ cell in oocytes is estimated to be much more.

The pregnancy was continued, because her fetus seemed not to have grave heart anomalies. During her pregnancy, maternal serum AFP was in the average level, but maternal serum hCG was over the 2.0 MOM (multiple of median) level in the third trimester.

\section{B 68}

MALE SEX CHROMOSOME ABNORMALITIES DETECTED IN CHILDHOOD.

Tomoko HASEGAWA (Div. Clin. Genet. Shizuoka Children's Hospittal, Shizuoka), Masako KONDO (Div. Endocrinol. S.C.H., Shizuoka), Yasuo HORIKOSHI, TOshihiro KOSHIDA (Div. Neonatol. S.C.H., Shizuoka), Kazumasa USUDA (Div. Urol. S.C.H., Shizuoka), Kazuhiko TANIGUCHI (Div. Orthoped. S.C.H., Shizuoka), Hideo AIBA (Div. Ped. Neurol. S.C.H., Shizuoka) and Koichi ENDO (Div. Clin. Path. S.C.H., Shizuoka).

We report sex chromosome abnormalities which were detected in male children with congenital abnormalities. There were ten patients: four had genital anomalies $(47, \mathrm{XXY}, 46, \mathrm{XY} / 47, \mathrm{XXY}, 46, \mathrm{XX}, 45, \mathrm{X} / 46, \mathrm{XY}\rangle$, two had radio-ulnar synostosis ( $47, \mathrm{XXY}, 47, \mathrm{XYY})$, three had MR/MCA (47,XXY, 47, XYY, 46, XY/47,XYY), and one had MR/hyperactivity $(47, \mathrm{XXY})$ without fra(X) chromosomes. Clinical findings in the two boys with MR/MCA were as follows: The boy with $47, \mathrm{XXY}$ had severe mental retardation, PierreRobin sequence, bifid scrotum and carpal fusion. The mother had 46,XX/ 47, XXX. The patient had an episode of perinatal asphyxia. The other boy with MR/MCA showed mild psychomotor delay, cleft palate, micrognathia and ear malformation. The father had a normal karyotype. Radio-ulnar synostosis has been examined cytogenetically in four boys over the last five years, and chromosome abnormalities has been found in two of these patients. 


\section{B 69}

VARIATIONS IN THE SIZE OF HETEROCHROMATIN IN THE CENTROMERIC REGIONS. Hiromi SAKAMOTO, Osamu MIKAMI. Masafumi HANDA. Yoshie SUGAWARA. Hiroko MINURA, and Jun-ich i FURUYAMA ( Dept. Genet. and Dept. Clin. Genet., Hyogo Col. of Med., Nishinomiya)

We found some peoples who had the larger constitutional heterochromatins in the centromeric regions using $G, Q$, and $C$ banding techniques. We found the dark extra bands proximal to the centromeres in the short arms. Variations detected with $G$ banding are rare.

The first case; we found the longer short arm of chromosome 4 at the prenatal diagnosis because of previous Down syndrome. After we decided that this chromosome was inherited from the father, we believed that this chromosome would have no associations with detectable phenotypic effect to the baby. The second case; the chromosome was examined for hydrocephalus and the result showed the longer short arm of chromosome 5. We found the same chromosome in his mother, then we decided this had no effect on his phenotype. The third case; he was referred to us just after born because of congenital anomaly. Chromosome examination showed the longer short arm of chromosome 17. We found the same chromosome in his father and decided this had no influence on his phenotype. The last case; we found the longer short arm of chromosome 19 after the chromosome examination from the wife, who consulted us about abortions. We decided that this chromosome might have no concern with previous abortions.

\section{B 70}

A SIMPLE AND EFFECTIVE METHOD FOR ESTABLISHING EPSTEIN-BARR VIRUSTRANSFORMED B-LYMPHOBLASTOID CELL LINE.

Keiko WAKUI ${ }^{1}$, Hirofumi OHHASHI ${ }^{2}$, Toshiro NISHIDA ${ }^{1}$, Tsutomu 0HISHI ${ }^{1}$ and Yoshimitsu FUKUSHIMA ${ }^{2}$ ('Dept. C1in. Lab., Saitama Child. Med. Ctr., Saitama, ${ }^{2}$ Div. Med. Genet., Saitama Child. Med. Ctr., Saitama)

B-1ymphoblastoid cell lines(LCL) obtained by transforming periferal blood B-lymphocytes using Epstein-Barr virus (EBV) are of great practical value in biochemical, cytogenetic and molecular reseach.

We report a more simple and effective method for establishing LCL: Add 3 volumes of Lysis buffer $\left\{155 \mathrm{mM} \mathrm{NH}{ }_{4} \mathrm{CL}, 10 \mathrm{mM} \mathrm{KHCO}{ }_{3}, 0.1 \mathrm{mM}\right.$ EDTA (pH7.4) $\}$ and $0.05 \%$ SDS to 1 volume of heparinized peripheral blood sample, and mix. After hemolysis $(30 \sim 60 \mathrm{sec})$, centrifuge $(1000 \mathrm{rpm}$, $5 \mathrm{~min}$.$) , and wash with medium once. Resuspend the cell pellet in RPMI$ 1640 with $20 \%$ fetal calf serum. $2 \mu \mathrm{g} / \mathrm{ml}$ of Cyclosporin $A$ and $0.1 \mathrm{ml} / \mathrm{ml}$ of the filtrated supernatant of B95-8 marmoset cel1 1 ine culture.

Start culture at $37{ }^{\circ} \mathrm{C}$ and $5 \% \quad \mathrm{CO}_{2}$. It takes only $15 \mathrm{~min}$. to start primary culture. Successful establishment of LCL was investigated even if a volume of sample was as small as $1 \mathrm{~m} 1$ of whole blood, and delay of starting culture was as late as 4 days after blood sampling.

Follpwing this protocol, LCL was successfully established in 70 of 71 samples (98.6\%) in our center during May and September, 1991. 


\section{B 71}

BREAKPOINTS OF RECIPROCAL TRANSLOCATION CHROMOSOMES IN MAN.

Hidetsune 0ISHI (Dept. Genet., Inst. Develop. Res., Aichi Pref. Colony, Kasugai) and Takasi YaMANAKA (Cent. Hosp., Aichi Pref. Colony, Kasugai)

Familial reciprocal translocations ascertained from probands were collected from our record and published papers. Of 514 families examined, unbalanced chromosomes of probands in 379 cases were produced by adjacent-1 segregation, and the others by adjacent-2 or 3:1. Male and female probands by the adj-1 were 188 and 181 , respectively, while their fathers and mothers with balanced conditions were 161 and 218 , respectively.

of cases by the adj-1, partial trisomy were analyzed in 250 probands and relative lengths of their unbalanced chromosomes were measured 1.31 (as \% of total haploid autosome length) in average, ranged 0.21 to 3.86 , and partial monosomy in 34 cases and the length 1.02 , ranged 0.35 to 1.93 , were also recorded. In addition, partial monosomy-trisomy, which were constructed by two breakpoints within arms, were found in 95 probands, and their unbalanced segments in partial monosomy and trisomy were 0.74 and 1.36 in average, respectively. These results were discussed in relation to the risk of abnormal offspring in the progeny of transiocation heterozygotes, and also postulated the existence of balanced carriers, who were never noticed abnormal pregnacies because of much larger unbalanced segments, for many generations.

\section{B 72}

A CONSTITUTIONAL MINUTE DELETTON ON CHROMOSOME \#22q IN A PATIENT WITH BILATERRAL ACOUSTIC NEUROFIBROMATOSIS. Tatsuro IKEUCHI ${ }^{2}$, Koich i ICHIMURA ${ }^{2,}{ }^{3}$, Kohtaro YAMAMOTO ${ }^{4}$, Kimiyoshi HIRAKAWA ${ }^{2}$, Yasuhito YUASA $^{3}$, and Akira TONOMURA ${ }^{1}$,

( ${ }^{1}$ Div. Cytogenet., ${ }^{4}$ Div. Virol. Immunol., Med. Res. Inst., ${ }^{2}$ Dept. Neurosurg., ${ }^{3}$ Dept. Hyg., Tokyo Med. Dent. Univ., Tokyo)

Bilateral acoustic neurofibromatosis (BANF) (or neurof ibromatosis type 2: NF2) is a dominantly inherited disease characterized by tumor development in the central nervous system, especially of the 8th cranial nerve. The gene locus for NF2 has been assigned to chromosome 22 (22q11.1-q13.1) by linkage studies. We presented a male patient ( 23 yrs) with BANF who showed a constitutional minute deletion on chromosome 22. His clinical features included: bilateral acoustic neurinomas, mental retardation, agenesis of corpus callosum, and hydrocephalus. High-resolution band studies at 850-band stage using cultured peripheral lymphocytes revealed a deletion of a subtle band 22q12.1 with breakpoints at q11.23 and q12.2. There were no other chromosome abnormalities. The parents were both healthy, and their chromosomes were normal. The present patient is the first known case of NF2 associated with a partial deletion chromosome 22, and the NF2 gene is now localized to the restricted region of $22 q 11.23-q 12.2$. 


\section{B 73}

SEGREGATION OF MICROPHTHALMTA AND CATARACT IN A FAMILY WTTH $t(2 ; 16)$ TRANSLOCATION. Yuji YOKOYAMA, Kouji NARAHARA, Kazushiro TSUJI, Ryuuko MURAKAMI, Hiroshi NAMBA and Yoshiki SEINo(Dept. Pediatr., Okayama Univ. Med. School, Okayama)

We report a family in which autosomal dominant congenital cataract with microphthalmia and $t(2 ; 16)$ translocation are segregating in ten members over three generations. The proband was born at 37 weeks gestation to unrelated parents. He was noted to have frontal bossing, congenital cataract with microphthalmia, hyperterolism, malformed ears, flat nasal bridge, down-turned mouth, shaw 1 scrotum, 11 ribs and VSD. He was refered to us at the age of 7 months for cytogenetic investigation. Cytogenetic studies performed on peripheral lymphocytes showed $2 \mathrm{p}$ trisomy. His mother also had congenital cataract and a balanced reciprocal translocation between chromosomes 2 and 16 with breakpoints at $\mathrm{p} 22.3$ and $\mathrm{p} 13.3$ respectively. Pedigree studies showed that two individuals with normal karyotype did not have cataract and all subjects with balanced and unbalanced translocation had congenital cataract with microphthalmia. Dot blot analysis with a biotinlabelled probe, pJW101 which exists on a terminal of chromosome $16 \mathrm{p}$, showed that the proband had only single copy of this gene. The ocular anomaly in this family is considered as MICROPHTHALMIA-CATARACT(McKUSICK 156850). We conclude that the gene of this disease can be assinged to the $16 \mathrm{p} 13.3$ region proximal to pJW101.

\section{B 74}

^ CASE OF THE LANGER-GIEDION SYNDROME WITH RECIPROCAL TRANSLOCATION INVOLVING CHROMOSOUE NUMBER 8 AND 13 . Noboru Fueki, Kazutaka Yamada, Masahiro Itoh, Mariko Sunahara, Yuko Inoue, Kiyoko Kurata and Asayo Ishizaki. (Dept. Pediatr., The Metropolitan Medical Center of Severely Handicapped, Fuchu, Tokyo)

Langer-Giedion syndrome is caused by the involvement of contiguous genes on a chromosome number 8 . Most investigators agree that the deletion points are detected at least $8 \mathrm{q} 23.3$ and $8 \mathrm{q} 24.1$. Cardinal features include cone shaped epiphyses, wultiple cartilagineous exostoses, microcephaly with mental deficiency and some dysmorphic condition (sparse scalp hair, bulbous nose, prominent philtrua, large protruding ears, et al). Some additional atypical findings are reported, for example, coloboma of the iris, microphthalmia, syndacty1y, cardiac defects and hypoplasia of the tibia.

We report a 31-year-old female case, who has multiple exostoses, severe mental and growth deficiency with microcephaly, defect of right tibia and dysmorphic face. Following high resolution methods, her chromosome formula is $[46, \mathrm{XX}, \mathrm{t}(8 ; 13)(8 \mathrm{pter} \rightarrow 8 \mathrm{q} 23.2:: 13 \mathrm{q} 31.2$ $\rightarrow 13$ qter; 13 pter $\rightarrow 13 q 31.2:: 8 q 24.11 \rightarrow 8$ qter $)]$. Frow wat we can gather previous reports, our case is the first Japanese patient of this syndrome with complex translocation associated with an $8 q$ deletion. 


\section{B 75}

CRANIOSYNOSTOSIS IN AN INFANT WITH dup(15)(q24 $\rightarrow$ q26.1). Hirofumi OHASHI ${ }^{1}$, Keiko WAKUI ${ }^{2}$, Toshi ro NISHIDA ${ }^{2}$, Jiro NISHIMURA ${ }^{3}$, Hiroshi NISHIMOTO ${ }^{4}$, Yoshimitsu FUKUSHIMA ${ }^{1}$ (Div. Med. Genet. ${ }^{1}$, Dep. Clin. Lab. ${ }^{2}$, Div. Plast. Surg. ${ }^{3}$, Div. Neurosurgery ${ }^{4}$, Saitama Children's Medical Center, Saitama)

Craniosynostosis has been noted in about 70 recognizable syndromes, and also described in various chromosomal aberrations. We reported here on a 17-monthold girl with craniosynostosis associated with partial trisomy $15 \mathrm{q}$.

The patient was noticed soon after birth to have following multiple congenital anomalies: brachycephaly, frontal bossing, low nasal root, exophthalmus, downward slanting of the palpebral fissures and camptodactyly of the 5th fingers. Skull $X$-ray films revealed early closure of the coronal and sagittal sutures, and increased digital markings. Her somatic growth and mental development were delayed. At age 13 months, a craniofacial surgery was performed.

Chromosome analysis revealed a de novo, unbalanced reciprocal translocation between $9 \mathrm{q}$ and $15 \mathrm{q}$, resulting in duplication of the $15 \mathrm{q} 24 \rightarrow \mathrm{q} 26.1$ segment. The karyotype was described as $46, \mathrm{XX},-9,-15,+\operatorname{der}(9)$ (9pter $\rightarrow 9 q 22.3:: 15 q 24 \rightarrow 15 q$ ter), $+\operatorname{der}(15)$ (15pter $\rightarrow 15 q 26.1:: 9 q 22.3 \rightarrow$ 9qter) de novo.

It is likely that duplication of $15 q 24 \rightarrow q 26.1$ is responsible for craniosynostosis in our patient. However, it cannot be ruled out that any of the breaks at $9 \mathrm{q} 22.3,15 \mathrm{q} 24$ or $15 \mathrm{q} 26.1$ involved in the translocation may actually disrupt the gene responsible for craniosynostosis.

\section{B 76}

DETECTION OF DNA POLYMORPHISM IN SOMATIC CELLS FROM A PATIENT WITH BILATERAL RETINOBLASTOMAS RESULTING FROM AN INTERSTITIAL DELETION OF CHROMOSOME 13. Tomoko HASHIMOTO, Osamu MIKAMI. Atsuko OGAWA, Kazue NAKAMURA, Hide-aki CHIYo, Jun-ichi FURUYAMA (Dept. Genet., Hyogo Col. Med., Nishinomiya), Takuma KONDO (Konohana Public Health Center, Osaka) and Ei-iohi TAKAHASHI, Tada-aki HORI (Division Genet. NIRS, Chiba)

A 3-year 7-month old boy, RBINI, who was diagnosed as bilateral retinoblastomas (RBs) at the age of 2 weeks and exhibited growth and developmental retardation with minor anomalies was examined for chromosomal abnormalities. The karyotype was $46, X Y,-11,-13,+\operatorname{der}(11)$ (1) lpter-q13. 1::13q22-qter); +der (13) (13pter-q14.1::11q13. 1qter). Southern blot analysis of RBINI DNA was performed using RB-cDNA located at 13q14. 1. esterase D (EsD)-cDNA at 13q14.1, and 5 RFLP chromosome 13 segments, $7 F 12$ at $q 12-q 14,7 D 2$ at $q 14,9011$ at $q 22,1 E 8$ at $q 22-q 31$, and $9 A 7$ at $q 33-q 34$, as probes. RFLPs were found with $7 F 12,1 E 8$, and 9A7, whereas no RFLP was found with ESD, 7D2, and 9D11. The intensity of the bands detected by RB-cDNA. EsD-cDNA and 7D2 was about half that detected by normal DNAs, indicating that the deletion was located between 7F12 and 9D11, which includes the RB. EsD, and 7D2 loci. Genomic DNA-PCR using RB1. 20 primers corresponding to the region $3^{\prime}$ to the exon 20 was performed. Although two bands were amplified from 7 control DNAs, a single band was obtained from RBINI DNA. These results confirm that only one RB allele exists in RBINI-DNA and suggest that $7 F 12$ is mapped at q12-13, 9011 at q22. 2-2q22.3, and $1 E 8$ at q22. 2-q31. 


\section{B 77}

MOLECULAR ANALYSIS OF THE BREAKPOINT IN A NF2 PATINET WITH CONSTITUTIONAL CHROMOSOME TRANSLOCATION $t(4 ; 22)$. ${ }^{1,2}$ Eiko ARAI, ${ }^{1}$ Takashi TOKINO, ${ }^{2}$ Tatsuro IKEUCHI, ${ }^{3}$ Kohtaro YAMAMOTO, ${ }^{2}$ Akira TONOMURA, ${ }^{1}$ Yusuke NAKAMURA ('Dept. Biochem. Cancer Inst. Tokyo, ${ }^{2}$ Dept. Genet., ${ }^{3}$ Dept. Viro. Immunol., Med. Res. Inst. Tokyo Med. Dent. Univ., Tokyo)

NF2 (Neurofibromatosis type 2) is an autosomal dominant genetic disease characterized with bilateral acoustic neurinoma and meningioma. The gene responsible for NF2 has been mapped to chromosome 22 by linkage analysis. We found a balanced translocation involving chromosome $22[t(4 ; 22)]$ in one of NF2 patients; the chromosomal breakpoint on chromosome 22 was at $q 12.2$; the same region as suspected by linkage analysis. To identify the translocation breakpoint that will permit cloning of the NF2 gene, chromosome 22specific plasmid library was constructed. Nearly 2,000 clones were isolated from the library and each of them has been used for examining a rearrangement by PFGE. As one of clones (p1107) showed extra bands specific to the patient with three rare restriction enzymes, it is suspected to be in close proximity to the breakpoint. We are now trying to isolate a YAC clone, which spans the breakpoint.

\section{B 78}

Further evidence supporting a contiguous gene hypothesis for X-linked dominant the Aicardi and the Goltz syndromes?

Yoshinori IZUMIKAWA, Kenji NARITOMI, Takaya TOHMA and Kiyotake HIRAYAMA (Dept. Pediatr., Univ. Ryukyus Sch Med, Nishihara, Okinawa)

Recently, we and Fukushima et al. reported a girl with a terminal Xp deletion, respectively. Because both patients had microphthalmia, linear focal dermal hypoplasia and agenesis of corpus callosum, we suggested that the genes responsible for the Aicardi and the Goltz syndromes should be contiguous.

In addition,we experienced three girls with microphthalmia partially overlapping to the Aicardi syndrome. Case 1, a 2-month-old girl, had microphthalmia OS, microcorneae, cataracts, persistent hyperplasia of primary viterous and ptosis. Hypoplasia of corpus callosum and cerebral atrophy were revealed by a MRI. Case 2, a 4-month-old girl, had short statute, cleft lip and palate, microphthalmia OS, cataracts, microcorneae, ptosis, persistent iridopupillary membrane, coloboma (optic nerve, choroid and retina), and malformed ears. Cerebral atrophy was revealed by a MRI. Case 3, a 18-month-old girl, had Peter's anomaly, nystagmus, and microphthalmia OS. Hypoplasia of corpus callosum and hippocampal area as well as agenesis of septum pellucidum were found by a MRI. All three patients had no seizures and a 46,XX karyotype. Although a computer database (PCDBMS), which consisted of 3600 syndromes and single cases, was applied to the diagnosis, it failled to confirm. Cases 1 and 3 had microphthalmia associated with hypoplasia of corpus callosum. Case 2 had microphthalmia and coloboma without hypoplasia of corpus callosum. These findings partially overlapped to the previous two cases with a Xp terminal deletion and the Aicardi syndrome. Furthermore, they were all females. Thus, these 3 cases may be evidence supporting a contiguous gene hypothesis for X-linked dominant the Aicardi and the Goltz syndrome. A molecular analysis using Xp terminal DNA probes should be indicated. 
B 79

A CASE OF PIERRE ROBIN SYNDROME WITIH $46, \mathrm{XX}, \mathrm{del}(\mathrm{X})$ (p21.1pter) or (p21.2pter). Yukihisa MATSUDA, Kaori MATSUYAMA, Kouichi MARUYAMA, Tadashi KANAME, Kouichirou MIYATA (Dept. Pediatr., Kagoshima Univ., Kagoshima) and Kenii NARTTOMT (Dept. Pediatr., Ryukvu Univ.. okinawal

Pierre Robin syndrome with chromosomal abberration is rare. We had a case of Pierre Robin syndrome with $46, \mathrm{XX}, \mathrm{del}(\mathrm{X})$ (p21.1pter) or (p21.2pter). The proband was a 2 month-year-old girl, and her parents were healthy and nonconsanguineous. She was born at 41 weeks after non-evevntful pregnancy. At birth, she was cured in incubator because of asphyxia due to micrognathia, glossoptosis, and cleft palate. At one month, she discharged, but had a respiratory stridor. At first visit of our hospital, her weight was $3,270 \mathrm{~g}(-2.8 \mathrm{SD})$, length $48.7 \mathrm{~cm}$. She had synophysis, deformed ears, cleft palate, micrognathia, and glossoptosis. Her karyotype was $46, \mathrm{XX}, \operatorname{del}(\mathrm{X})^{\circ}(\mathrm{p} 21.1 \mathrm{pter})$ or (p21.1pter). But locus of X-linked recessive cleft palate was Xq21, deferent from our case. In stigmata of Tuner syndrome, she had only short stature, which was phenotype of $\mathrm{X}$ deletion from $\mathrm{xp} 21$ to xter.

\section{B 80}

CLINICAL MANIFESTATIONS OF THE SMITH-MAGENIS SYNDROME. Ikuko KONDO(Univ. of the Ryukyus, Okinawa), Yoshimitu Fukushima(Sai tama Child., Med. Cent., Sai tama), Yoshihumi YAMAMOTO (Tokyo Keisatsu Hosp., Tokyo), Kayoko SHIMOGAKI (Koube Univ., Hyougo), Satoshi ISHIKIRIYAMA (Chiba Chil. Hosp), Tatsuya IsHIKAWA(Nagoya City Univ., Nagoya) and Yukihisa MATSUDA(Kagoshima Univ., Kagoshima)

Clinical manifestations in 12 patients with the SmithMagenis syndrome were summarized. Sex ratio(male: female) was 5:7. Mean paternal and maternal ages at the birth were 31.1 and 27.0 years, respectively. Main clinical manifestations were mental retardation, abnormal behavior, abnormal facial appearance with brachycephaly, broad forehead, hypoplastic midface, mongoloid slant, and thick lips, and broad short hands with short fingers. A partial deletion of the short arm of the chromosome $17[\operatorname{del}(17)$ (p11.2p11.2)] was observed in patients. Three patients had been diagnosed clinically to have Down's syndrome. Chromosome analyses with specific attention to the short arm of chromosome 17 is necessary to diagnosis this deletion in patients with facial apparance of Down's syndrome. 


\section{B 81}

KABUKI MAKE UP-TURNER SYNDROME: REPORT OF 7 PATIENTS.

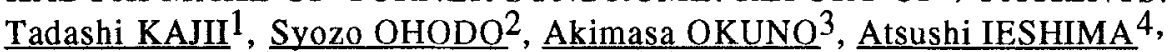
Ichiro MURANO ${ }^{1}$, Masato TSUKAHARA ${ }^{1}{ }^{1}$ Dept. Pediatr., Yamaguchi Univ. School Med, Ube;2Dept. Pediatr., Miyazaki Med. Col., Miyazaki ; ${ }^{3}$ Dept. Pediatr., Asahikawa Med. Col., Asahikawa ; ${ }^{4}$ Kaiki children's Ryouiku Center, Tottori)

Kabuki make up syndrome and turner syndrome share several clinical features induding short stature, large palpebral fissures, occassional congenital cardiac disease, scoliosis and short metacarpals. Seven girls are reported with a karyotype of Turner syndrome and clinical features of Kabuki Make up syndrome (eversion of the lower lateral eyelids, arched eyebrows, large prominent ears, depressed nasal tip, hypoplastic columella, and fingerpads). Four girls had a 45, X, r(X) karyotype, two were $45, X / 46, X, i(X q)$, and one was $45, X$. The ring $X s$ in three girls were small, while the remaining one was large. Fulorescence in situ supression hybridization analysis with $\mathrm{X}$-and $\mathrm{Y}$-centromeric probes proved that the ring $\mathrm{Xs}$ in three girls studied were indeed ring $\mathrm{Xs}$.

\section{B 82}

Cytogenetic and molecular findings of two $\mathrm{fra}(\mathrm{X})$ heterozygous carriers in the same family. Ryozo KASAI (Asahigawa Jidoin Child. Hosp., Okayama), Kouji NARAHARA, Kazushiro TSUJI, Yuji YOKOYAMA, Masae MURAKAMI, Yoshiki SEINO (Dept. Pediatr., Fac. Med., Okayama Univ., Okayama), Yutaka NAKAHORI and Yasuo NAKAGOME (Dept. Cong. Abn., Nat1. Child. Med. Res. Ctr., Tokyo)

It is acknowledged that the $\mathrm{fra}(\mathrm{X})$ inactivation pattern is related to the mental status in $\mathrm{fra}(\mathrm{X})$ heterozygous carriers. Two fra $(X)$ heterozygous carriers were ascertained by family study of two fra(X) male proband. Carrier 1, a mother of the probands, had normal intelligence (IQ 93), while carrier 2, a younger sister of the carrier 1, showed severe mental retardation (IQ 22). The frequenvy of FdU induced fra $(X)$ in carrier $2(19 \%)$ was significantly higher than that in carrier $1(8 \%)$. However, the frequency of the early replicating fra $(X)$ was similar to each other $(62 \%$ in carrier 1 and $63 \%$ in carrier 2). Southern blot analysis using the DNA probe, cloned by Nakahori et a1. (1991), showed different hybridyzation patterns in the two carriers. These findings suggest that the phenotypes of the two heterozygous carriers may be determined by genomic imprinting in fra $(X)$ gene rather than fra(X) inactivation. 


\section{B 83}

A FOLLOW UP STUDY OF DOWNS SYNDROME(4) -THE IMMUNOLOGY AND ALLERGY OF 84 DOWNS INFANTS- : R. TSUKINO, M. SASAKI, S. UEMURA, Y. MINAMI, T. YANAGAWA, H. NEGORO, H. SUZUKI and M. KOIKE. Wakayama Medical College, Department of Pediatrics, Wakayama.

We studied the clinical immunological characteristics of 84 patients with Downs syndrome. 1. The rate of allergic diseases was $11 / 84(13 \%)$ in Downs syndrome by inquiry to their mothers. (atopic dermatitis(8), bronchial asthma(2) and milk allergy(1)). All with atopic dermatitis were very mild and those with asthma and milk allergy were relatively servere. 2. Very low IgE antibody level were observed(mena $\pm S D 28 \pm 43 \mathrm{IU} / \mathrm{ml}$, $\max 264 \mathrm{IU} / \mathrm{ml}$ ), but their IgG, $\mathrm{A}$ and $\mathrm{M}$ levels were slightly higher. 3. The maximum serum concentrations of $\mathrm{IgE}$ were found below $38 \mathrm{IU} / \mathrm{ml}$ in 3 with asthma and milk allergy. 4. The appearance of eosinophils in peripharal blood specimen were low(mean \pm SD $1.5 \pm 1.7 \%$ and maximum $12 \%$ ). 5. The occurence of allegic diseases in Downs syndrome is apparently lower compared to their siblings. 6 . These result coincide well with clinical observations that allergic diseases are rare among infants with Downs syndrome.

\section{B 84}

A FOLLOW UP SIUDY OF DOWNS SYNDROME (5) -THE LIPID METABOLISM OF 84 DOWNS INFANTS- : M. SASAKI, R. TSUKINO, S. UEMURA, Y. MINAMI, T. YANAGAWA, H. NEGORO, H. SUZUKI, and M. KOIKE. Department of pediatrics, Wakayama Medical College, Wakayama.

We studied clinically the lipid metabolisms of 84 cases with Downs syndrome(DS). 1. The mean values of serum total cholesterol (T.C), trigryceride(T.G), and atherosclerotic index(A.I) were higher and HDL-C was lower in DS infants than age matched control. 2. The A. I was always higher in infants with DS, and low level of HDL-C seemed to make A.I higher. 3. Judging by Muratas criteria(T.C $\geqq 200$ $\mathrm{mg} / \mathrm{d} 1, T . G \geqq 160 \mathrm{mg} / \mathrm{d} 1$, $\mathrm{HDL}-\mathrm{C} \leqq 40 \mathrm{mg} / \mathrm{d} 1$ and $A . I \geqq 3)$, the rate among DS who showed abnormal

values during the observation period was compared to the normal infants reported by Murata. T.C : DS 32\%-normal 7.6\%, A.I : 50\%-2.3\%). 4. Comparison made the difference of cholesterol levels before and after the open heart surgery between DS group $(n=15)$ and non-DS group ( $\mathrm{n}=28$, with VSD) revealed higher increase in DS group. In conclusion, the lipid metabolism of the child with DS is easily influenced by the environment changes and nutritional guidance is needed. 


\section{B 85}

MULTIPLEX PCR ANALYSIS FOR DELETIONS IN DYSTROPHIN GENE FROM JAPANESE PAT IENTS WITH DUCHENNE OR BECKER MUSCULAR DYSTROPHY.

Kazuo TAKEMURA, Masayosh i TSUTSUMI', Ke ij i IIDA', Yuki tosh i ISHIKATA? Ryoji MINAMI" , Kazumasa HIKIJI ${ }^{1}$ ('SRL Inc., Tokyo, ${ }^{2}$ National Yakumo Hospital, Hokkaido)

The multiplex PCR analysis described by Chamberlain et al.(1988,1990) and Beggs et al.(1990) are capable of detecting deletions in the deletion prone "hot spot" region of the dystrophin gene. He have analyzed seventy unrelated Japanese patients with DMD/BMD(67 DMD and 3 BMD) with the two multiplex reactions. The frequencies of deletion detection were $30 \%(21 / 70)$ with nine primer sets of Chamberlain et al. (exon $4,8,12,17,19,44,45,48$ and 51 ) and $29 \%(20 / 70)$ with ten primer sets of Beggs et al. (exon 3,6,13,43,47,49,50,52,60 and muscle promoter), respectively. When analyzed with both primer sets, the frequency of deletion detection increased to $36 \%(25 / 70)$. Deleted patterns were very heterogeneous. In the "hot spot" region, deleted site frequencies were $8 \%(2 / 25)$ in the 5 ' site(promoter to exon 19$)$ and $92 \%(23 / 25)$ in the central domain(exon 43 to 60 ). Moreover, we observed 6 samples which were suspected of duplication by visual inspection of relative band intensity.

\section{B 86}

ANALYSIS OF THE DYSTROPHIN GENE IN DUCHENNE / BECKER MUSCULAR DYSTROPHY. Natsuki IMOTO' ${ }^{1}$, Kiichiro MATSUMURA ${ }^{3}$, Tadao ARINAMI ${ }^{2}$, Hiroki YAMADA $^{3}$, Kenzo HAMANO', Junko FUJLWARA', Hitoshi TAKITA ${ }^{1}$, Hideo HAMAGUCHI ${ }^{2}$ ( ${ }^{1}$ Dept. Pediatr., ${ }^{3}$ Dept. Med. Genet., Univ. Tsukuba, Tsukuba, ${ }^{2}$ Dept. Neurol., Shimoshizu Natl. Hosp., Yotsukaido)

Duchenne muscular dystrophy (DMD) is common among severe single-gene disorders, with an incidence of 1 in 3,500 live born males. The incidence seems to be similar among different races. It has been speculated that the high incidence is due to a high mutation rate in the dystrophin gene which is a giant gene up to $2400 \mathrm{~kb}$. Therefore the type of mutation may be similar among different races. We have analyzed the dystrophin gene in Japanese DMD/Becker muscular dystrophy (BMD) to clarify this point. Using dystrophin cDNA as probes, Southern blot analysis was performed in unrelated 95 Japanese DMD/BMD patients (DMD:BMD=90:5). We detected partial gene deletions in 55(57.9\%) patients and partial duplication in $7(7.4 \%)$. These gene rearrangements distributed non-randomly in the dystrophin gene: $37(60 \%)$ patients had a breakpoint in cDNA 7-8 region and $10(16 \%)$ had a breakpoint in cDNA 1-2a region. Both of the distribution pattern of rearrangements were well matched with the major and minor hot spots reported in Caucasian patients. These results indicate that the type of mutation, rate of rearrangement, and mutation hot spots in Japanese DMD/BMD are similar to those in Caucasian DMD/BMD. 


\section{B 87}

MOLECULAR GENETIC AND IMMUNOLOGICAL ANALYSIS OF DYSTROPHIN IN PATTENTS WITH BECKER MUSCULAR DYSTROPHY (BMD). Kiyoko IKEYA, Kayoko SAITO, Akemi YAMAUCHI, Eijiro OZAWA* and Yukio FUKUYAMA. (Dept. of Pediatrics, Tokyo Women's Medical College, Tokyo; ${ }^{\star D i v}$. of Cell Biology, Natl. Inst. of Neuroscience, NCNP, Tokyo.)

Two cases with in-frame deletions at Duchenne muscular dystrophy (DMD) gene are reported. Case 1 was a 6 -year-old boy with a relatively severe clinical course. Southern blot analysis revealed a deletion of exons 10 to 37 . Analysis of transcripts disclosed that the mRNA lacked the sequence of exons deleted in the gene, and that the splicing sites flanking the deletion were preserved. Immunological analysis using four antibodies suggested that the correct amino acid sequence was maintained downstream from the deletion. Case 2 was a 5-year-old boy with fever and/or exercise-induced myalgia. An inframe deletion of exons 47-49 was found. An abnormal dystrophin with altered size and reduced quantity was detected on the muscle cell membrane by immunological analysis. In both cases, antiserum directed against the deleted region did not react at all with muscle specimens. These findings were compared with those of reported cases in which DNA and proteins were examined. Both molecular genetic and immunological analysis are necessary for making a clinical diagnosis also investigation of the structure-function relationships in dystrophin.

\section{B 88}

CARRIER DETECTION USING LYMPHOCYTE DNA AND mRNA IN DUCHENNE (DMD) AND BECKER (BMD) MUSCULAR DYSTROPHY.

Akemi YAMAUCHI, Kayoko SAITO, Kiyoko IKEYA, Takayo HARADA, Yukio FUKUYAMA. (Dept. of Pediatrics, Tokyo Women's Medical College, Tokyo.)

We detected DMD/BMD carriers in 31 DMD/BMD families with family tree analysis, serum CK level, and Southern blot analysis using cDNA probes. The new mutation rate was revealed in the family of sporadic patients. [Subject] The subjects selected for the present study included the mothers of $31 \mathrm{DMD} / \mathrm{BMD}$ patients. High serum CK level were observed in $12 / 31$ families (38.7\%). By family tree analysis, 5/31 (16.1\%) were diagnosed as either definite or probable carriers. The mothers were diagnosed as carriers by the detection of gene dose and junctional fragment of Southern blotting. In one family, PCR using lymphcytes mRNA was studied. [Results and Conclusions] Gene deletions were observed in 19/31 families(61.3\%). 16 of these 19 families(84.2\%) were diagnosed as the sporadic patients identified by family tree analysis. In 11 of the 16 families (68.8\%), the mothers were diagnosed as confirmed carriers, because of the deletion in their DNA. The patients of the remaining 5 families(31.2\%) were confirmed as new mutations because the deletion in the patients were not detected in the mother's DNA. In one family, a deletion, which was detected with Southern blotting, was comfirmed with PCR using lymphcyte mRNA in a female member of the family. 


\section{B 89}

DNA ANALYSIS OF DUCHENNE MUSCULAR DYSTROPHY-ESTABLISHING THE OPTIMM STRATEGY FOR CARRIER DIAGNOSIS IN JAPANESE POPULATION-.

Susumu KATAYAMA, TOmOne YANO, Naoki TAKESHITA, Shi aot ing CHOU, Harumi KUBO, KazUO MONOSE(The 1st Dept. Obst. Gynecol. , Toho Univ., Tokyo) and

Tsuneyuki Ubagai (Dept. microbiology. . Toho Uni v. , Tokyo)

DNA analysis was performed on 19 unrelated DMD families and one BMD family in Japan to determine their carrier status. The intragenic genomic probe pERT 87 with its subclones $87-1,87-8$ and $87-15$ were used together with five kinds of CDNA probes from the 5 , end of the dystrophin gene. The tests with both a high $P$. I. C and a high observed P.I.C were most effective 1 , e. pERT $87-1 / \mathrm{Xmn} 1$, pERT 8 ? $-15 / \mathrm{XmnI}$, pERT 87-8/TaqI, and pERT 87-8/BstNI. These test combinations were useful in Japanese population but pERT 87-15/Taql was not, although it was effective in Caucasians. Two additional test combinations of pERT 87-1/MspI and pERT 87-15/Bam HI were highly useful in detecting RFLPS when other tests were not informetive. Carrier status could be determined in 18 out of 20 clients who were at risk for DMD/BMD carriers status from 20 families, similar to the rate of detection in Caucasians. The total detection rate of deletions was $74 \%$ with the five CDNA probes. Deletions were concentrated on two hot spots where 92 \% of all deletions were detected by only two probes, 1-2a and 8. Deletions were detected in two males with DMD who had none of the eight RFLPS tested. Our results emphasise the usefulness of DNA analysis with pERT 87 genomic probes and CDNA probes. In addition, an optimum strategy for carrier detection in Japanese DMD/BMD families was proposed.

\section{B 90}

MOLECULAR GENETIC DIAGNOSIS OF DUCHENNE AND BECKER MUSCULAR DYSTROPHY -- A COMPARISON OF PCR AND SOUTHERN BLOT ANALYSIS --.

Kayoko SAITO, Akemi YAMAUCHI, Kiyoko IKEYA, Yukio FUKUYAMA. (Department of Pediatrics, Tokyo Women's Medical College, Tokyo)

Approximately 50-60\% of Duchenne(DMD) and Becker muscular dystrophy (BMD) patients exhibit DNA deletions. Recently, Chamberlain et al. introduced a rapid and efficient method of screening for such deletions by using inultiplex polymerase chain reaction(PCR) amplification. We modified the multiplex PCR for this study, and compared the results with those obtained by Southern blotting using cDNA probes. In $2 / 10$ cases, we found discrepancies between the two methods. In one case, we confirmed a false-positive PGR by using a different set of primers. In the other, a false-negative Southern blotting result may have occurred because of a change in the size of the band, which represents a junctional fragment. The PCR is also effective for detection of the dystrophin muscle promotor, and we have identified one individual with deletion of the muscle promotor. Multiplex PCR amplification can be used screening for DNA abnormalities with appropriate precautions to avoid misdiagnosis. 


\section{B 91}

MAPPING OF 10 HUMAN GENES USING FLOW-SORTED CHROMOSOMES AND FLUORESCENCE IN SITU HYBRIDIZATION. Shinsei MINOSHIMA. Ryuichi FUKUYAMA. Yuuka ICHIJOH, Susumu NAKAZAWA Kosuke SAKAI. Masamichi HIRAI Jun KUDOH and Nobuyoshi SHIMIZU (Dept. Mol. Biol., Keio Univ. Sch. Med., Tokyo, Japan)

We have performed the chromosomal localization of human genes by a combination of spot-blot hybridization to flow-sorted human chromosomes and fluorescence in situ hybridization. Using these methods, we were able to localize the following ten human genes to particular regions of human chromosomes: (1) $230-\mathrm{kDa}$ bullous pemphigoid autoantigen (BPAG1) to chromosome 6pter-q15; (2) hepatocyte growth factor (HGF) to chromosome 7q21.1; (3) L-gulono- $\gamma$-lactone oxidase nonfunctional gene (GULO) to chromosome $8 \mathrm{p} 21.1$; (4) cytochrome $c_{1}$ (CYC1) to $8 \mathrm{q} 24$; (5) 80K-L protein (MACS), a substrate for protein kinase C, to chromosome 6; (6)MACS-related sequence (MACSL1) to chromosome 21; (7) brain-specific 14-3-3 protein, tyrosine hydroxylase and tryptophan hydroxylase activator (YWHA1), to chromosome 22; (8) SP-40,40 sulfated glycoprotein, complement lysis inhibitor (CLI), to chromosome 8; (9) glial fibrillary acidic protein (GFAP) to chromosome 17 ; (10) long-chain-fatty-acidCoenzyme A ligase (FACL1) to chromosome 4.

[We thank Drs. M. Amagai, T. Nishikawa, N. Kitamura, M. Nishikimi, K. Yagi, R. Kuwano, Y. Takahashi, T. Kumanishi, T. Tobe and T. Yamamoto for their collaborative efforts.]

\section{1}

NONSENSE CODON MUTATIONS OF THE ORNITHINE AMINOTRANSFERASE GENE WITH DECREASED LEVELS OF MUTANT mRNA IN GYRATE ATROPHY. Yukihiko MASHIMA (Dept. of Ophthalmol., Keio Univ., Tokyo, Japan), Richard G. WELBER, Nancy G. KENNAWAY(Oregon Health Sciences Univ., Oregon, USA), Lorne CLARKE(Univ. of British Columbia, Canada), Takashi SHIONO(Dept. of Ophthalmol., Tohoku Univ., Sendai, Japan), George INANA(Bascom Palmer Eye Institute, Miami, USA)

Gyrate atrophy (GA) is an autosomal recessive eye disease involving a progressive loss of vision due to chorioretinal degeneration where ornithine aminotransferase (OAT) is defective. We have identified five new nonsense codon mutations of the OAT gene by using PCR, DGGE, and direct sequencing. Three of them are due to single base changes (codon 209, 299, 426) and two are due to deletions resulting in a reading frameshift (newly generated codon 79, 192). Nonsense codon mutations at codon 79,192 , and 209 result in abnormally low levels of OAT mRNA. The mutations at codon 426 in the last exon, however, has little effect on the mRNA level. The norma1 length of OAT is 439 amino acids. The mRNA level can be reduced by nonsense codon mutations, but the position of the mutations may be important with earlier premature translation termination having a great effect than a later mutation. 


\section{2}

Analysis of mitochondrial DNA and genetic counseling in Japanese families with Leber's hereditary optic neuropathy (LHON). T. Yajima ", Y.Hotta",F. Ara",M.Hayakawa", Atsushi Kanai" Keiko Fujiki ${ }^{1)}$,Makoto Nakamura ${ }^{2)}$.Jo Sakai ${ }^{27}$,Misao Yamamoto ${ }^{2}$,Jo Imachi ${ }^{2)}$ (Dept.Ophthalmol., ${ }^{1}$ Juntendo Univ., Tokyo and ${ }^{2}$ Kobe Univ.,Kobe Univ.,Kobe)

Leber's hereditary optic neuropathy (LHON) is a maternally inherited disease characterized by severe visual loss. A mitochondrial DNA (mtDNA) mutation (G to A transition at nucleotide position 11778 converting the 340th arginine to histidine in the NADH dehydrogenase subunit 4) detected as Sfa NI and Mae III site polymorphism was identified in about $50 \%$ of cases of definite LHON. We already reported that it provided a simple diagnostic test. We analyzed 12 families, 16 cases and 7 carriers with Japanese LHON employing Sfa NI and Mae III. Leukocyte pellets or cultured lymphocytes transformed by EB virus of the cases were obtained from the peripheral blood and high molecular weight DNAs were isolated. PCR (polymerase chain reaction) amplification was performed and PCR products were cut by the restriction enzymes. The mutation in nucleotide position (nt) 11778 of mtDNA was identified in 11 families, 16 cases and 7 carriers. Although genetic heterogeneity was recognized in Japanese LHON, the nt 11778 mutation was more frequently detected in Japanese LHON than previous reports. We performed the genetic counseling using this information in Juntendo University.

\section{3}

GM2-GANGLIOSIDOS IS B1 VARIANT: THE ORIGIN AND THE PHENOTYPE OF DN-ALLELE. Akemi TANAKA (Dept. Pediat. Osaka City Univ. Sch. Med., Osaka), M. Rosário dos SANTOS, M. Clara sá MIRANDA (Inst. Genét. Méd. Jacinto Magalhães, Porto, PORTUGAL). Kunihiko SUZUK I (Brain \& Development Res. Ctr. Univ. North Carolina, Chapel Hill, NC, U.S.A.)

GM2-gangliosidosis B1 variant is a neurodegenerative disorder resulting from the genetic $\beta$-hexosaminidase $\alpha$ defects. It is enzymologically unique in that $\beta-$ hexosaminidase $A$ is catalitically normal if tested with conventional artificial substrates but is inactive to hydrolyze natural GM2-ganglioside and sulfated artificial substrates. The clinical profile of the patients with Bl variant is late-infantile or juvenile form. Two point mutations of a subunit gene were

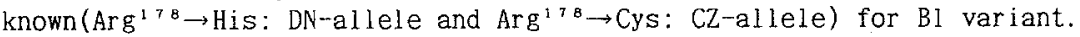

Analysis of a subunit gene in seven patients reported in 1990 showed that five patients were compound heterozygous and one (Spanish patient) was homozygous for DN-allele. Bl variant occurs at an exceptionally high frequency in the Northern part of Portugal. We have analyzed the $\beta$-hexosaminidase $\alpha$ gene in eleven Potuguese patients. In contrast with our previous study, ten patients were homozygous and one were compound heterozygous for DN-allele. That suggests that DN-allele may have originated in Portugal. Clinical phenotype of homozygous patients were juvenile form, and compound heterozygous patients showed severer and variable clinical pictures. It is suggested that the total residual activity of the mutant enzyme protein generated by the double dose of the DN-allele is sufficient for thr juvenile phenotype and the clinical phenotype of DN-allele compound heterozygotes should depend on the nature of the second abnormal allie. 


\section{4}

DNA ANALYSIS FOR APRT DEFICIENCY BY NON-RADIOACTIVE METHOD

Hiroko HIGASHIMOTO ,Takayuki NAGAOKA, Ryuji KAWAGUCHI and Kazumasa HIKIJI (Genetic Research Laboratory , SRL Inc. , Tokyo)

Adenine phosphoribosyl transferase (APRT) deficiency is a genetic disorder involved 2,8-dihydroxyadenine urolithiasis and renal failure among Japanese. There are two known types of causative genes for this deficiency ; APRT ${ }^{*} J$ (approx. 80\% in Japanese APRT deficiency) lead to the abnormal APRT synthesis partially lacked APRT activity because of its low affinity to the specific substrate, while $A P R T^{*} \otimes D(12 \sim 13 \%)$ results completely lacked the activity. An improved method enable us to detect these two causative genes in almost all patients with Japanesese APRT deficiency. We reported the hypersensitive dot blot assays for $A P R T^{*} J$ and $A P R T^{*} 60$ mutation using allele specific oligonucleotides and a chemi luminescent substrate. Furthermore, we reported the ARPT gene analysis for some other causative genes using the direct sequence methods by non-isotopic dideoxy sequencing.

\section{5}

MOLECULAR ANALYSIS OF 3-KETOTHIOLASE DEFICIENCY. A COMPOUND HETEROZYGOTE WITH A POINT MUTATION (347Ala TO Thr) AND AN MUTATION WHICH ABOLISHES MRNA EXPRESSION.

Toshiyuki FUKAO, Seiji YAMAGUCHI, Tadao ORII (Dept. Pediatr., Gifu Univ., Gifu), Takashi OSUMI (Dept. Life Sci., Himeji Inst., Hyogo), and Takashi Hashimoto (Dept. Biochem., Shinshu Univ., Matsumoto)

The molecular basis of 3-ketothiolase deficiency (3KTD) was examined in a 3KTD family. Immunochemical analyses showed that mitochondrial acetoacetyl-CoA thiolase (T2) biosynthesized in the patient's fibroblasts (GK06) was unstable and that the parents and brother were obligatory carriers of 3KTD. When sequencing the PCR-amplified patient's T2 cDNA, we noted a $G$ to A replacement which caused $347 \mathrm{Ala}$ to Thr substitution of the mature T2 subunit. Transfection analysis revealed that this substitution resulted in an instability of the T2 protein. Analyses of the $\mathrm{T} 2 \mathrm{cDNA}$ and gene of the family indicated that the patient was a compound heterozygote; the allele that derived from the mother had a point mutation (347Ala to $\mathrm{Thr}$ ) and the other allele from the father has a mutation which would abolish the T2 gene expression. This report is apparently the first definition at the gene level of a mutant allele for 3KTD. This report was published in Biochem. Biophys. Res. Commun. 179:124-129, 1991. 


\section{6}

IDENTIFICATION OF HETEROZYGOTES OF 3-KETOTHIOLASE DEFICIENCY, USING IMMUNOBLOTTING

Seiji YAMAGUCHI, Toshiyuki FUKAO, Atsuko SAKAI, Akihiro WAKAZONO, Tadao Orii (Dept.Pediatr.Gifu Univ., Gifu) and Takashi HASHIMOTO (Dept.Biochem.Shinshu Univ.Sch.Med., Matsumoto)

3-Ketothiolase deficiency (3KTD) is a congenital organic acidemia, showing an autosomal recessive inheritance. The disorder is caused by a deficiency of mitochondrial acetoacety1-CoA thiolase (T2). Acetoacetyi-CoA thiolase (AA-CoA-T) activity of $\mathrm{T} 2$ is activated by the presence of $\mathrm{K}$ ion, and so the ratio of $\mathrm{AA}-\mathrm{CoA}-\mathrm{T}$ activities in the presence of $\mathrm{K}$ ion /in the absence is 1.0 in case of the patients with 3KTD, while that of controls was about 2.0 (range 1.8-2.4). When the ratio in fibroblasts from the parents (heterozygotes) was determined, it ranged 1.4-2.0, that was overlapped with those in the controls. It was concluded that the AA-CoA-T assay could not clearly identify the heterozygotes. We performed immunoblotting of T2 with two antibodies against mitochondrial 3-ketoacyl-CoA thiolase (T1) and $\mathrm{T} 2$ simultaneously, and tested the intensity of the bands densitometrically. When the ratio of the two peak areas for $T 1$ and $\mathrm{T} 2(\mathrm{~T} 2 / \mathrm{T} 1)$ was calculated, those of patients, parents and norma1 controls were $0.0,0.06-0.29$, and $0.36-0.79$, respectively. We concluded that heterozygotes of 3KTD can be clearly identified by immunoblot analysis using the two antibodies simultaneously.

\section{7}

IDENTIFICATION OF 2 MUTATIONS CAUSING SILENT PHENOTYPES OF HUMAN SERUM BUTYRYLCHOLINESTERASE IN JAPANESE FAMILIES.

Kazuo HIDAKA, Iwao IUCHI, Toshiko YAMASAKI(Dept. Biochem., Kawasaki Med. Sch., Kurashiki), Masaki OHHARA(Mitoyo Genl. Hosp., Kagawa), Takaaki SHODA(Ehime Univ. Hosp., Ehime) and Bert N. LADU(Univ. Michigan Med. Sch., USA)

There are three phenotypes, dibucaine-resistant, fluoride-resistant and silent forms in serm buytrylcholinesterase $(\mathrm{BChE})$ variants. However, these phenotyping methods are incapable of distinguishing between the different sub-type of silent variants. Recently, we have carried out DNA analyses on five homozygous silent individuals from three unrelated families to determine the exact structural abnormality in their BCHE gene. DNA was isolated from white blood cells and the BCHE coding region of BCHE gene was amplified by PCR method using specific primers. The amplified DNA was sequenced by direct sequencing methods. The first instance demonstrated a $G \rightarrow C$ transversion at codon 365 (GGA $\rightarrow$ CGA), which was seen in three of the two families. This mutation was resulted to create a new Taq 1 site. The second mutation was shown by a double heterozygous condition with twodifferent silent gene mutations in two of remaining one family. These mutations were as follows. 1) one type was a frameshift mutation, in which an extra A was inserted in codon 315( $\mathrm{ACC} \rightarrow \mathrm{AACC}$ ) and the other was the same point mutation at codon 365 as seen in the first instance. 


\section{8}

IDENTIFICATION OF MUTANT HPRT GENES IN PATIENTS OF LESCH-NYHAN SYNDROME AND PARTIAL HPRT DEFICIENCY USING THE PCR TECHNIQUE. Yasukazu YAMADA, Haruko GOTO, Nobuaki OGASAWARA (Dept. Genet., Inst. Developmental Res., Aichi Pref. Colony, Aichi)

Five independent mutations in hypoxanthine guanine phosphoribosyltransferase (HPRT) genes from a patient of partial HPRT deficiency associated with gout and from four patients of Lesch-Nyhan syndrome, have been identified using the technique of polymerase chain reaction (PCR) coupled with direct sequencing. In HPRT gene from a patient of partial HPRT deficiency (case 1), a single nucleotide substitution at codon 188 (GTT to GCT) was idetified, which is resulting in a single amino acid substitution of Val to Ala with the decrease of HPRT activity. Two independent point mutations were detected in the HPRT genes from the patients of Lesch-Nyhan syndrome. The single amino acid substitution of Ala (GCC) to Pro (CCC) at codon 64 (case 2), and that of Leu (CTG) to Gln (CAG) at codon 78 (case 3 ) were detected. In other two mutants causing Lesch-Nyhan syndrome, deletions associated with missing of RNA splicing were lound. The $4 \mathrm{bp}$ deletion at the $5^{\text {'-end }}$ of exon 4 resulted in three different types of abnormal mRNA (case 4). The other mutant (case 5) had the abnormal mRNA including $26 \mathrm{bp}$ in the intron 8 instead of the deleted $58 \mathrm{bp}$ at the 5 '-end of exon 9 , because of the deletion of $74 \mathrm{bp}$ from intron 8 to exon 9 in the genomic DNA.

\section{9}

Divergence of phenotypes in $\beta$-galactosidase deficiency Akihiro OSHIMA, Kunihiro YOSHIDA, Hitoshi SAKURABA, Yoshiyuki SUZUKI (Dept. Clin. Genet. Tokyo Metropolitan Inst. Med. Sci.)

Gene mutations of acid $\beta$-galactosidase resulted in GM1gangliosidoses and Morquio B disease. The GM1-ganglisidoses produce at one end of spectrum patients with acute infantile onset and severe neuro-somatic manifestations, and at the other end of spectrum patients with chronic adult onset and mild neurological manifestations. Patients with Morquio B disease have presented with progressive skeletal dysplasia, but without neurological impairment. To clarify the reasons of wide spectrum of clinical manifestations, we studied the gene mutations and their expression products. Results: 1) mutations were heterogeneous among the patients with infantile GMl-gangliosidosis. The exression products of these mutant genes were almost compeletely lack of enzyme activity. 2) Mutant genes I51T, R201C and W273L were commom and specific among the patients with adult GM1-gangliosidosis, juvenile GM1-gangliosidosis, and Morquio B disease respectively. Some redidual activity (5-20\%) was detected in expression products of these mutant genes. 4) Sorting in Golgi apparatus and complex formation in lysosomes were disturbed in the products of mutant gene $\mathrm{I} 51 \mathrm{~T}$ and $\mathrm{R} 201 \mathrm{C}$ respectively. In mild clincal course $\beta$ galactosidase deficiency, these specific characteristics in intracellular processing and turnover of mutant enzymes may be associated with the divergence of phenotypic expressions. 
C 10

$\beta$-galactosidase deficiency: genotype-phenotype relationship Kunihiro YOSHIDA, Akihi ro OSHIMA, Hitoshi SAKURABA. Yoshiyuki SUZUKI (Dept. Clin. Genet., The Tokyo Metro. Inst. Med. Sci., Tokyo)

Eleven different utations vere identified in patients vith $\beta$ galactosidase deficiency (GMl-gangliosidosis and Morquio B disease); tro duplications and nine single base substitutions. The genetic basis of infantile GM1-gangliosidosis ras heterogeneous, but connon and specific gene utations vere found in adult/chronic GM1-gangliosidosis and Morquio B disease. $51 \mathrm{Ile}(\mathrm{ATC}) \rightarrow \operatorname{Thr}$ (ACC) and $273 \mathrm{Trp}$ (TGG) $\rightarrow$ Leu (CTG) vere found in seventeen Japanese adult/chronic patients and three patients vith Morquio $B$ disease, respectively. These tro iutant genes and $201 \mathrm{Arg}(\mathrm{CGC}) \rightarrow$ Cys(TGC), which was reported to be connon in Japanese juvenile/late infantile patients (Nishinoto et al. An. J.Hum.Genet. 49: 566-574, 1991), expressed sone anounts of the enzye activity in adenovirus-SV40 recombinants transformed fibroblasts from an infantile patient. These specific mutations with residual enzyme activity probably determine the phenotypic expression of $\beta$-galactosidase deficiency with ild clinical course.

\section{11}

Molecular basis of infantile type galactosialidosis.

Michie Shimmoto, Akihiro Oshima. Hitoshi Sakuraba. Yoshivuki Suzuki (Dep. Clinical Genetics, The Tokyo Metropolitan Institute of Medical Science)

Galactosialidosis is a hereditary metabolic disease characterized by a combined deficiency of lysosomal $\beta$-galactosidase and neuraminidase due to the genetic defect of a protective protein(PP). It is clinically heterogeneous with regard to the age of onset, phenotypic expresson, severity and prognosis. We divided galactosialidosis patients clinically into the flowing 2 groups; type I with generalized and severe manifestation of neonatal onset, and type II mainly with neurological manifestation of later onset, and futher dividedtype II patients into subtype IIA (severe) and IIB (moderate). It was previously reported that type IIB patients revealed a common gene rearrengement E7S: an A-to-G base substitution at the position $3 b p$ downstream of exon 7, resulting in skipping of this exon in $m R N A$, and they were homozygote for this mutation. In this study molecular analysis was performed on 3 patients of type I and 4 patients of typellA and 5 rearrengements were detected in their cDNA. One of them, A-to-G base substitution at the codon 367 is common among 4 patients ( 2 patients of type 1,2 patients of type IIa). A variety of base substitutions were identified in the PP gene from the type I patients. The type IIA patients were heterozygous for the E7S allele and another allele involved one of the mutations found in type I galactosialidosis. The clinical phenotype was reflected by the combination of these mutations. 


\section{12}

ATTEMPT TO DETECT FIBRONECTIN MUTANT GENE AND THE STUDY ON EXPRESSION OF PROTO-ONCOGENES, IN SCLERODERMA FIBROBLASTS. Akihide OHTA, Fumitaka MORITO, Megumi HIIDA, and Masaya YAMAGUCHI (Dept. Intern. Med., Saga Med. Sch., Saga)

Recently, it was reported that the scleroderma patients had the fibronectin mutant gene, which might be associated with the pathogenesis of this disease. In order to confirm the presence of the mutant gene, we have analyzed DNA from the cultured scleroderma fibroblasts. PCR-amplified DNA including cell-binding domain of the fibronectin gene from both scleroderma and control cells did not have Smal cutting site, which should have existed if the reported mutation occurred. Moreover, direct sequence analysis revealed no presence of the mutant gene. These results along with recent reports of the negative results using DNA from scleroderma mononuclear cells suggest that the fibronectin mutant gene may be restricted to the rare group of scleroderma patients. In addition, to examine the mechanism of activation of scleroderma fibroblasts, we have analyzed the expression of various proto-oncogenes in these cells. The expression of c-myc, c-fos, and c-H-ras genes showed no difference between scleroderma and control fibroblasts, whereas that of $\alpha_{1}(I)$ procollagen and fibronectin was elevated in some scleroderma cells. A c-sis expression, though low in both cells, slightly increased in scleroderma cells, suggesting the possible mechanism of PDGF-associated autocrine activation of scleroderma fibroblasts.

\section{13}

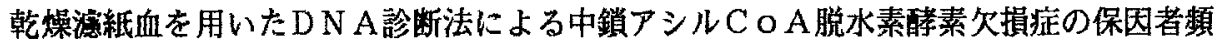

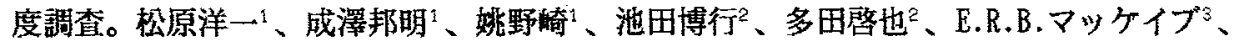

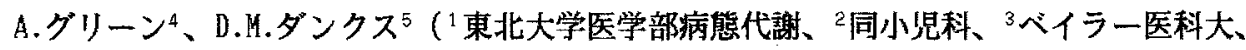

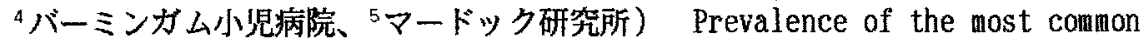
mutation in the medium-chain acyl-CoA dehydrogenase gene determined from Guthrie cards. Y. MATSUBARA ${ }^{1}$, K. NARISAWA ${ }^{1}$, Y. YAO ${ }^{1}$, H. IKEDA ${ }^{2}$, K. TADA ${ }^{2}$, E.R.B. MCCABE ${ }^{3}$ A. GREEN ${ }^{4}$ D.M. DANKS ${ }^{5}$ (Dept. of ${ }^{1}$ Biochemical Genetics and ${ }^{2}$ Pediatrics, Sendai, ${ }^{3}$ Baylor College of Med., Houston, ${ }^{4}$ Birmingham Children's Hosp, Birmingham, ${ }^{5}$ Murdoch Inst., Melbourne)

中鎖アシルCOA脱水素酵素欠損症はライ症候群様の症状を呈し、また乳幼児突然死の原 因ともなるために近年注目を集めている常染色体劣性遺伝疾患である。昨年われわれは、 本疾患における最も頻度の高い遺伝子变異(K329E)を明らかにし、さらにこの変異を乾燥 滤紙血を用いて簡便迅速に検出するDNA骖断法を確立した。この方法を用いて英国、米国、 オーストラリアの一般新生児1,368人をスクリーニングした結果、22人の本遺伝子変異保 因者を同定した。（保因者頻度：1/62人）。今回の研究によって、将来これらの国にお ける、DNA診断法を用いた中鎖アシルCOA脱水素酵素欠損症のマススクリーニングの可能 性が示昗された。しかしながら、本変異は日本人新生览500人には検出されず、また、中 鎖アシルCOA脱水酵素遺伝子のRFLPハプロタイプI型との間に連鎖が誌められることから、 本変異の白人におけるfounder effectを示唆しているものと考えられた。 


\section{14}

DENATURING GRADIENT GEL ELECTROPHORESIS OF PCR-AMPLIFIED DNA FRAGMENTS (PCR-DGGE) FOR DETECTION OF VARIATION IN DNA. PART 3. Norio TAKAHASHI, Chiyoko SATOH, Jun-ichi ASAKAWA, Mieko KODAIRA, Keiko HIYAMA, Hideo OMINE, and Yasukazu KIMURA (Dept. of Genetics, Radiation Effects Research Foundation, Hiroshima)

In order to evaluate the potential genetic effects of the atomic bombs, it is necessary to choose techniques that can examine as many nucleotides as possible at one time. PCR-DGGE appears to be effective technique for this purpose. On the basis of the data from preliminary examinations, we attempted to simplify the PCR-DGGE method to make it more suitable for a large-scale screening. In our procedure, PCR amplified target sequences of 2 to $3 \mathrm{~kb}$ were digested by restriction enzyme(s) and the resulting about 500 bp-fragments were subjected to DGGE. When 2 amplified target sequences were mixed and examined on a single lane after they were independently digested with restriction enzyme(s), all of the variants existing in both targets could be clearly separated. Thus, by using this method, about $160 \mathrm{~kb}$ per diploid genome could be examined on a 20 -wells gel. Here, we present the data on human factor IX gene from 63 families. When 4 targets, total of about $6.9 \mathrm{~kb}$, were examined, 10 types of new hereditary base substitutions were detected. From the experiences of this study, we think PCR-DGGE is effective and practicable for screening for mutations.

\section{15}

CHARACTERIZATION OF 2 GENES ENCODING PHOSPHOGLYCERATE KINASE-1 (PGK1) WITH ACTIVITIES TWICE HIGHER THAN THE NORMAL VALUE BY USING PCR-HIGH PERFORMANCE LIQUID CHROMATOGRAPHY (PCR-HPLC). Chiyoko SATOH, Jun-ichi ASAKAWA, Norio TAKAHASHI, Akiko MIURA, and Hideo OMINE (Dept. of Genetics, Radiation Effects Research Foundation, Hiroshima)

In the screening of 9,637 children of atomic bomb survivors for mutations that alter PGK1 activities, three hereditary variants were detected in three families. Two of them showed activities twice higher than the normal value. DNA and RNA were extracted from cell lines established from B-lymphocytes from 3 male children including 2 siblings with high activity variants and normal males. A 481 bp sequence in the 5'-flanking region of the $P G K 1$ gene on X-chromosome and a 1668 bp sequence in cDNA reverse transcribed from $P G K 1 \mathrm{mRNA}$ were amplified by PCR and examined by denaturing gradient gel electrophoresis. No sequence differences were observed between the variant and the normal males. The sequence of $1220 \mathrm{bp}$ spanning between exon 9 and exon 11 in the $P G K 1$ gene was amplified by PCR and quantity of PCR-product was estimated by HPLC. The products from the 3 children were twice more than those obtained from the normal males. Pulsed-field gel electrophoresis of the DNA from the 3 children suggested that types of duplications of the normal PGK1 gene which had occurred in the two families were different. 
C 16

MOLECULAR ANALYSIS OF LEUKOCYTE ADHESION DEFICIENCY; DISTINCT MUTATIONS IN THREE JAPANESE FAMILIES.

Shinya MATSUURA, Fumio KISHI, Masato TSUKAHARA, Tadashi KAJII (Dept. Pediatr., Yamaguchi Univ. Sch. Med., Ube) and Kunihiko KOBAYASHI (Dept. Lab. Med., Hokkaido Univ. Sch. Med. Sapporo)

Leukocyte adhesion deficiency (LAD) is an autosomal recessive disorder characterized by recurrent bacterial infections, impaired pus formation and delayed wound healing. The primary defect in LAD resides in $\beta$ subunit $(C D 18)$ common to three adhesion proteins; LFA-1, Mac-1 and p150,95. In order to determine the molecular basis of the disorder, RT-PCR and sequencing analyses were performed of RNAs derived from the patients and other members of three unrelated Japanese families. Leukocytes from two sibs in Yamaguchi, which synthesize an aberrant large $\beta$ subunit mRNA, showed $1.2 \mathrm{~kb}$ insertion that corresponds to an intron of the $\beta$ subunit gene, resulting from a mutation in a splice donor site. The other two patients, each from a different family, each had a distinct single base substitution that resulted in an amino acid change in the highly conserved region of the $\beta$ subunit protein.

\section{17}

ASSOCIATION OF ALCOHOLISM WITH THE A1 ALLELE OF THE DOPAMINE D2 RECEPTOR GENE TaqI RFLP IN JAPANESE. Masanari ITOKAWA, Michio TORU (Dept. Psychiatry, Tokyo Med. Dent. Univ., Tokyo), Tadao ARINAMI, Hideo HAMAGUCHI (Dept. Med. Genet., Univ. of Tsukuba, Tsukuba), Tokutaro KOMIYAMA, Hiroshi MITSUSHIO (Nat. Inst. of Neuropsychiatric Disorder, Tokyo), Hiroshi MORI (Asai Hosp, Togane), and Hideo MIFUNE (Hatsuishi Hosp. Kashiwa)

A possible association between alcoholism and a restriction fragment length polymorphism (RFLP) recognized by the dopamine $\mathrm{D}_{2}$ receptor (DRD2) gene clone $\lambda \mathrm{hD} 2 \mathrm{Gi}$ was recently reported. In the present study, we examined the allelic association of the dopamine $\mathrm{D}_{2}$ receptor gene with alcoholism in 78 unrelated Japanese alcoholics and 86 unrelated controls. Significantly higher frequency of the A1 allele was found in the Japanese controls compared with those reported in the white populations: the A1 allele frequency was 0.44 and the $\mathrm{A} 1$ allele existed in $70 \%$ of controls. The A1 allele was present in $68 \%$ of 41 more severe alcoholics and $56 \%$ of 27 less severe alcoholics. There was a significant correlation between the severity and the period from the onset in the alcoholics with the $\mathrm{Al}$ allele, but no such a correlation was observed in those without the A1 allele. Homozygotes for the $\mathrm{A} 1$ allele were found in $15 \%$ of the controls and $12 \%$ of the alcoholics. All alcoholics homozygous for the $\mathrm{A} 1$ allele were classified as severe. The average severity of alcoholism increased in the order $\mathrm{A} 2 / \mathrm{A} 2, \mathrm{~A} 1 / \mathrm{A} 2$, and $\mathrm{A} 1 / \mathrm{A} 1$ genotypes. These data suggest that the $\mathrm{A} 1$ allele is associated with the progression of alcoholism, though it is not associated with the susceptibility to alcoholism in most cases. 


\section{18}

PCR-SSCP ANALYSIS OF POLYMORPHISM IN DPA1 AND DPB1 GENES. Shuji HOSHINO, Yasuhiko FUKUDA, Kiyohiko DOHI (2nd Dept. Surg.,Hiroshima Univ.,Hiroshimal and Akinori KIMURA, Takehiko SASAZUKI (Dept. Genet., Kyushu Univ., Fukuoka)

<-A new technical trial was carried out to detect polymorphism in HLA-DP genes, based on the diversity in electrophoretic mobility of single stranded DNA (single strand conformation polymorphism, SSCP). Genomic DNAs were subjected to PCR to amplify the polymorphic exon 2 of DPA1 or DPB1 genes. The PCR samples were denatured by heating in the presence of formamide, electrophoresed in a neutral polyacrylamide gel and visualized by silver staining. Fifteen DPB1 alleles showed 11 distinct electrophoretic patterns, leaving four allelic cambinations indistinguished. These four allelic combinations could be further distinguished by using another couple of primers in PCR, with which a part of the exon was amplified and by subsequent SSCP analysis. The use of four pairs of primers in PCR allowed the discrimination of the all 15 DPB1 alleles tested. Two allelic differences in exon 2 of DPA1 gene could be clearly demonstrated. In addition, a new DPB1 and three new DPA1 alleles were detected by this SSCP analysis. The PCR-SSCP analysis is simple and rapid, requires neither radioactive materials nor restriction enzymes and thus may be an useful tool for investigating the fine $\mathrm{HLA}$-matching in transplantation.

C 19

ANALYSIS OF POLYMORPHISM IN EXON 2 OF HLA-B GENE Masayuki YOSHIDA ${ }^{1) 2)}$, Akinori KIMURA ${ }^{1)}$, Fujio NUMANQ ${ }^{2)}$, and Takehiko

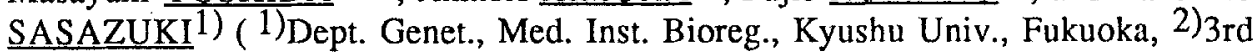
Dept. Int. Med., Tokyo Med. Dent., Univ., Tokyo, Japan )

We have applied directed PCR to DNA typing of HLA-B antigens in combination with SSOP and SSCP analysis. HLA-B specific 5' sided primer (CG4/CG5) and $3^{\prime}$ sided primers (CG2 and CG3) were designed for the exon 2 of HLA-B gene. HLA-B alleles were divided into two groups by PCR with two types of $3^{\prime}$ sided primers (CG2 and CG3). The amplified DNAs were then hybridized with 21 SSOPs endolabeled with nonradioactive digoxigenine. We investigated 90 cell lines homozygus for HLA selected in 10th HLA workshop and 111 Japanese panel donors. 37 HLA-B alleles were classfied into 25 groups and 18 alleles were directly determined their specificity. In addition, SSCP of the amplified DNA showed several distinct electrophoretic patterns in a neutral polyacrylamide gel. These analyses allow, at least in part, the DNA typing of HLA class I antigens. 
C 20

Characterization of mutations in three male patients with ornithine transcarbamylase deficiency : Toshinobu MATSUURA ${ }^{1}$, Ryuuji HOSHIDE ${ }^{1}$, Chiaki SETOYAMA ${ }^{2}$, Kazunori SHIMADA ${ }^{3}$, Toshihiko YANAGAWA ${ }^{4}$, Gen MIYAGI $^{5}$,Mitsuharu KAJITA ${ }^{6}$ and Ichiro MATSUDA ${ }^{1}$ (Departments of ${ }^{1}$ Pediatrics and ${ }^{2}$ Biochemistry, Kumamoto University Medical School. ${ }^{3}$ Department of Medical Genetics, Division of Molecular Biomedicine, Research Institute for Microbial Diseases, Osaka University. ${ }^{4}$ Department of Pediatrics, Wakayama Medical College. 5 Okinawa Chuubu Hospital. ${ }^{6}$ Kamo Hospital. )

OTC deficiency ( an X-linked disease ) is liver-specific enzyme that catalyzes the second step of the urea cycle. The deficiency in hemizygous patients have hyperammonemia, coma, and death in childhood. To analyze mutations responsible for OTC deficiency in three male patients, we used the PCR to amplify all exons and exon/intron junctions. Then, we found mutants in two patients which were in exon 8. One mutation resulted in appearance of new $\mathrm{HgaI}$ site and the other resulted in disappearance of NlaIII site. To analyze the segregation pattern of the normal and mutant OTC alleles, the family study was conducted by $\mathrm{HgaI}$ and NlaIII digestions of the amplified DNAs. We found that the mutation in the patient seems to have been acquired de novo in the family and that the mother is carring one normal and one mutant OTC gene in other family.

\section{21}

MOLECULAR BASIS AND POPULATION GENETICS OF PKU IN ORIENTALS. Yoshiyuki Okano, Gen Isshiki (Dept. Pediatr., Osaka City Univ. Med. School,0saka), Yutaka Hase (Children's Med. Center of Osaka, Osaka), Jun-Ichi Furuyama (Dept. Genet., Hyogo Col. Med., Nishinomiya), Toshiaki Oura (Osaka Municipal Rehabilitation Center, Osaka), Dong-Hwan Lee (Dept. Pediatr., Soon Chun Hyang, Univ.,Soul), and Tao Wang, Savio L.C. Woo (Baylor Col. Med., Houston)

The frequency and distribution of eight 0riental mutations (R111X, IVS4, Y204C, R243Q, IVS7, W326X, Y356X, R413P) in Japan and Korea were examined using allele-specific oligonucleotide hybridization method. These mutant alleles comprised 50\% and 55\% of all PKU chromosomes in Japan and Korea, respectively. We found the spectrum of PKU mutations in Japan similar to those in China, especially in north China, and those in Korea different from China and Japan. The IVS4 mutation, which originated in south China, especially showed high frequency, which might have been caused by the founder effect and genetic drift. We were not able to find Caucasian mutations in the Japanese and Korean PKU chromosomes. It could be concluded that PKU mutations occured after racial divergence between the Caucasians and the Mongolians, and there were distinct founding populations for PKU in different parts of the world. 


\section{22}

GENE ANALYSIS FOR ARGININEMIA BY USING POLYMERASE CHAIN REACTOIN. Takako UCHTNO, Yougo HARAGUCHI, Juan M. APARICIO R. (Dept. Pediatr., Kumamoto Univ., Kumamoto), Masataka MORI (Institu. Med. Genet., Kumamoto Univ., Kumamoto), Ichiro MATSUDA (Dept. Pediatr., Kumamoto Univ., Kumamoto)

Argininemia is an autosomal recessive disorder caused by a genetic deficiency of hepatic arginase activity. Previously we described two discrete frame-shift deletions in the arginase gene from a patient with argininemia. Now we analyzed another patient with argininemia by using polymerase chain reaction (PCR) amplification, cloning and sequencing of arginase gene.

We found two point mutations which had not been described. One of the mutation was a single base substitution ( $G$ to $A$ at position 365 in exon 4) that resulted in the generation of a stop codon (TAG) from a codon for Trp (TGG). The other was a mis-sense mutation (G to $C$ at a position 705 in exon 7) that resulted in the replacement of Gly (GGA) with Arg (CGA). Expression tests indicated that both mutations abolished the arginase activity.

Familial studies indicated that the patient was shown to be a compound heterozygote, inheriting an allele with the nonsense mutation (stop codon) from the mother and the other allele with the mis-sense mutation from the father.

\section{23}

MOLECULAR GENETIC ANALYSIS OF PYRUVATE DEHYDROGENASE (PDH) DEFICIENCY: DETECTION OF MUTATIONS OF E1 $\alpha$ GENE IN FEMALE PATIENTS.

Michinori ITO, Takahiko SAIJO, Etsuo NAITO, Eiji TAKEDA, and Yasuhiro KURODA (Dept. Pediatr., Sch. Med., Univ. Tokushima, Tokushima)

PDH deficiency is the most common cause of congenital lactic acidemia. PDH $\alpha$ subunit $(E 1 \alpha)$ gene was mapped on $X$ chromosome. In this sudy, we detected the mutations of $\mathrm{E} 1 \alpha$ gene in two female patients with PDH deficiency, diagnosed by measurement of enzyme activity and immunoblot analysis of the enzyme. Nucleotide sequencing of E1 $\alpha$ cDNA from the fibroblasts showed 4-bp and 18-bp insertion in the two patients, respectively. The analysis of genomic DNA and cDNA showed that these patients were heterozygotes of normal and mutant alleles but only the mutant allele was expressed in most of the patient fibroblasts. Our results suggest that in these patients, $X$ chromosome containing normal allele was predominantly inactivated so that they showed clinical symptoms in spite of heterozygote of normal and mutant alleles. However, in cultured cells or tissues, which are used to measure the enzyme activity, from female patients with PDH deficiency, $X$ chromosome containing the normal allele may be predominatntly activated so that the enzyme activity may be normal. Therefore, in the diagnosis of female patients with PDH deficiency, the measurement of the enzyme activity is not always reliable. 


\section{24}

The mutation of rhodopsin gene in a Japanese family with autosomal dominant retinitis pigmentosa (ADRP). Keiko FUJIKI ${ }^{1}$, Yoshihiro HOTTA', Mutsuko HAYAKAWA', Hitoshi SAKUMA ${ }^{1}$ Atsushi KANAI', Takashi SHIONO ${ }^{2}$, Mitchiru NORO ${ }^{2}$, Takehiko SAKUMA ${ }^{2}$, Makoto TAMAI ${ }^{2}$ (Dept. Ophthalmol., 'Juntendo Univ., Tokyo and 'Tohoku Univ., Sendai)

Retinitis pigmentosa $(\mathrm{RP})$ is characterized by visual field loss, night blindness, and fundus changes, including bone corpuscle lumps of pigment. RP is clinically and genetically heterogeneous. After Dryja et al.(1990) found the mutation of codon 23,58 or 347 in an allele of the rhodopsin gene on chromosome $3 \mathrm{q}$ in ADRP patients, several mutations and a $3-b p$ deletion in the rhodopsin gene in ADRP patients have been identified.

We have analyzed 20 unrelated Japanese families including 29 patients with ADRP. High molecular weight DNAs were isolated from peripheral white blood cell. A DNA fragment between nucleotide position 5168 and 5829 of the rhodopsin gene was amplified by means of polymerase chain reaction (PCR). PCR products of DNA were cut by restriction enzyme Nci I and Msp I which is able to detect the codon 347 mutation of the rhodopsin gene, respectively. We found a family with the mutation of codon 347 in an allele of rhodopsin gene, of which the transition from CCG to CTG (Pro-347-Leu) was detected by sequencing. This mutation had been transmitted from proband's mother to proband and his two daughters. Their clinical findings were most likely type I ADRP. The mutation of rhodopsin gene appears to be the cause of one form of ADRP since it was found in Japanese ADRP which is different ancestry from families reported by Dryja et al.

\section{25}

SIGNIFICANCE OF MICROTIA FOR BIRTH DEFECTS MONITORING PROGRAM.

Ken j i KUROSAWA, Ki yosh i IMA IZUMI, and Yosh i kazu KUROKI

(Div. Med. Genet., Kanagawa Childrens' Medical Center)

To estimate the significance of microtia as a marker anomaly, we investigated the incidence of microtia and associated anomalies in KAMP (Kanagawa Birth Defects Monitoring Program) registered during 6 years and 9 months. The incidence of microtia was about $3.0 / 10.000$ births and no racial differences were observed. Same smoking rate was proved in the mothers with microtia infants and those with total birth defects. Both paternal and maternal ages were significantly elevated in the microtia group with associated anomalies than in the isolated microtia group. Cleft 1 ip and/or palate, ocular defects, and $1 \mathrm{imb}$ defects were frequently associated with microtia. Chromosome anomalies were obserbed frequently in microtia infants. We concluded that microtia was a very valuable trait to detect teratogenic factors in birth defects monitoring program. 


\section{26}

ULTRASOUND SCREENING OF NEWBORN INFANTS FOR KIDNEY AND URINARY TRACT ABNORMAIITIES. Akira MATSUI, Michiko AOKII), Tsunehisa TAKENAKA ${ }^{2}$ ) (Dept. Pediat!? and obstet \& Gynecol.,2) Isesaki Municipal Hospital, Gunma) and Masamichi HAYASI, 3) Hidetosi YAMANAKA (Dept.Urol., Gunma Univ., Gunma)

Ultrasound examination of the kidney and urinary tract was performed on 1,715 newborn infants. Mean + SD of anteroposterior and longitudinal diameter of the nörmal kidney in newborn period was estimated at $2.28+0.206 \mathrm{~cm}$, and $4.35+$ $0.288 \mathrm{~cm}$ respectively, while that of ānteroposterior diame ter of the renal pelvis was $0.17+0.10 \mathrm{~cm}$.

out of 1,715, a total of 20 cases (1.17 \%) of kidney and urinary tract abnormalities was screened out. Hydronephrosis was found in 6 cases, vesicoureteral reflux in 7 , multicystic kidney in 4, simple cyst in 1, and duplicated ureters in 2. In addition, adrenal hemorrhage was observed in 3 cases and neuroblastoma in 1 .

In conclusion ultrasound screening may be useful for rapid detection of silent kidney and urinary tract abnormalities in newborn infants.

\section{27}

STATISTICAL ANALYSIS OF GENETIC DISEASES IN PEDIATRIC PRACTICE AT A SUBURBAN CENTRAL HOSPITAL. Hiroshi NAKAI, Youko FURUGOHRI, Masako HIROTA, Mayuki KOMATSUSHIRO and Taku SASAKI (Dept. Pediatr., Iwate Pref. Central Hospital, Iwate)

Iwate Prefectural Central Hospital is one of leading hospital in a Iwate Prefecture, about $600 \mathrm{~km}$ northeast of Tokyo. In the pediatric department, during last two years we had about 700 patients admission in a year. And among them neonatal patients were $12 \%$ ( 83 neonates). As for genetic disorders, $21 \%$ of 700 in-patients were diagnosed as chromosome aberration, single gene disorder or multifactorial disease. If clinical geneticist had one more subspecial ability, he or she will have so many needs in a general hospital. And also clinical geneticist can play important roles as a general practician. We have genetic clinics in two prefectures (Iwate and Miyagi). Training program, advices to parental association for handicapped children and information network is also our practices in this field. 


\section{28}

LINKAGE ANALYSIS OF JUVENILE PARKINSONISM WITH AUTOSOMAL RECESSIVE INHERITANCE (JP TYPE 1) USING HIGHLY POLYMORPHIC DNA MARKERS. Hajime TANAKA ${ }^{1}$, Atsushi ISHIKAWA ${ }^{1}$, Yusuke NAKAMURA ${ }^{2}$, Tadashi MIYATAKE ${ }^{3}$, and Shoji TSUJI ${ }^{1}{ }^{1}$ Dept. of Neurol., Brain Res. Inst., Niigata Univ., Niigata; ${ }^{2}$ Division of Biochem., Cancer Inst., Tokyo; ${ }^{3}$ Dept. of Neurol., Tokyo Med. and Dent. Univ., Tokyo)

Highly polymorphic DNA markers are indispensable for linkage analysis of hereditary diseases. Application of the polymerase chain reaction (PCR) to type polymorphic DNA markers such as the (CA)n block markers consumes less DNA and is faster than conventional RFLP analysis. We performed linkage analyses of juvenile parkinsonism with autosomal recessive inheritance (JP type 1) using highly poly morphic DNA markers by analyzing genomic DNA from 28 members of 8 Japanese JP type 1 families containing 12 affected individuals. We used the method of pairwise linkage analysis (MLINK subprogram of LINKAGE) for genetic linkage to dinucleotide repeat loci (ASS:9q32-q34, CRP:1q21-q23, D1S117:1q23-q25.1) and variable number of tandem repeat (VNTR) loci (pYNZ2:1, pYNH24:2p, pEFD134.7:3p, MCOC14:4p, pMHZ10:9q). The lod scores derived from pairwise linkage analyses with JP type 1 locus and three dinucleotide repeat markers, ASS, CRP, and D1S117, were $-\infty,-\infty$, and $-\infty(\theta=0.00) ;-1.932,-3.319$, and $-2.440(\theta=0.05) ;-0.692$, 1.997, and $-1.162(\theta=0.10)$. Linkage to these loci was excluded in a total of approximately $54.5 \mathrm{cMo}$.

\section{29}

LINKAGE DISEQUILIBRIUM BETWEEN JAPANESE DM LOCUS AND A NEW POLYMORPHIC DNA MARKER. Hidehisa YAMAGATA, Yuji TAKEMOTO, Tetsuro MIKI and Toshio OGIHARA (Dept.Geriat.Med.,Osaka Univ.Med.Sch.,Osaka)

Myotonic dystrophy(DM), which is an autosomal dominant trait, affects muscle and numerous other tissues. Associated features include myotonia, muscle wasting, cataract, hypogonadism, frontal balding and ECG changes. Linkage analysis suggests a single locus for DM on 19q 13.2-q13.3. Several RFLPs have been identified that are closely linked to the DM locus. The order of DNA markers is as fo1lows: cen-D19S19-APOC2-D19S63-p37.1-p36.1-D19S62-qter. These markers are so close that it is hard to order these markers by conventional linkage analysis. The detection of linkage disequilibrium may enable us to pinpoint the DM gene by using haplotype analysis. We examined D $19 \mathrm{~S} 19$ (Pst I $/ \mathrm{A}_{1}=19 \mathrm{~kb}, \mathrm{~A}_{2}=11 \mathrm{~kb}$ ), APOC2 (Taql/ $\mathrm{B}_{1}=3.8, \mathrm{~B}_{2}=3.5$ ), D 19S63(Pvul $/ \mathrm{C}_{1}=7.1, \mathrm{C}_{2}=6.8, \mathrm{C}_{3}=6.5$ ), p37.1(BamHI/ $\left.D_{1}=5.6, D_{2}=5.3\right)$ haplotype in Japanese DM pedigrees, and detected strong linkage disequilibrium between DM gene and p37.1 $(p<0.001)$. From the linkage disequilibrium analysis, it appears that p37.1 is the marker closest to Japanese DM gene. Further disequilibrium analysis should enable us to determine more exactly the location of DM mutations around p37.1. 


\section{30}

A NEW VARIANT GENE FOR N-ACETYLTRANSFERASE FOUND IN JAPANESE. Masako ABE, Masami MASHIMO, Tomokazu SUZUKI (Dept. C1in.Genet., Med. Inst. Bioregulation, Kyushu Univ., Beppu), and Takeo DEGUCHI (Dept. Molecular Neurobio1., Tokyo Met. Inst. Neurosciences., Fuchu)

Polymorphism of N-acetyltransferase (EC 2.3.1.5, NAT) has been we11 documented pharmacogenetically by the isoniazid test for determining phenotype. Recently we characterized three types of alleles of human NAT gene, and correlated three phenotypes with five genotypes which were generated by the combination of 2 alleles. Thus RFLP recognized by KpnI and BamHI has been used for predicting each phenotype. During the typing of genomic DNA from 148 unrelated individuals, we found a new variant of NAT allele (gene 4) in four individuals which had no KpnI site in exon 2. In one family gene 4 run over three generations. One nucleotide alteration in gene 4 introduced the replacement of amino acid(Ile-114 by Thr) though the disappearance of KpnI site didn't cause amino acid substitution. Gene 4 seemed to cause slowly metabolizing protein because a heterozygote of gene 4 and gene 3 was typed as a slow acetylator by isoniazid test. Based on nucleotide sequences in exon 2 of four alleles which were distinguishable by TaqI, Asp718 (isoschizomer of $\mathrm{KpnI}$ ), and BamHI, we have developed new genotyping method by PCR based RFLP by these enzymes.

\section{31}

HLA AND IMMUNOGLOBULIN GENES MAY CONFER SUSCEPTIBILITY TO DILATED CARDIOMYOPATHY

Hirofumi NISHI ${ }^{1,2}$, Akinori KIMURA ${ }^{2}$, Haruhito HARADA ${ }^{1,2}$, Yoshinori KOGA $^{1}$, Hironori TOSHIMA ${ }^{1}$ and Takehiko SASAZUKI ${ }^{2}\left({ }^{1}\right.$ Third Dept. Int. Med., Kurume Univ., Kurume, ${ }^{2}$ Dept. Genet., Med. Inst. Bioreg., Kyushu Univ., Fukuoka)

To identify genetic factors especially in the immune system which control the susceptibility to dilated cardiomyopathy (DCM), HLA-class II DNA typing was performed by using PCR/SSOP method in 61 Japanese patients. The frequencies of HLA-DQB $1 * 0503\left(15 \%\right.$ vs $\left.5 \% ; R R=3.06, \chi^{2}=7.19\right)$ and $\mathrm{DQB} 1 * 0604(21 \%$ vs $10 \%$, $\mathrm{RR}=2.41, \chi^{2}=6.20$ ) were significantly increased and that of HLA-DQB $1 * 0502$ $(R R=1.74)$ was slightly increased in the patients. On the other hand the frequency of DQB $1 * 0303\left(16 \%\right.$ vs $31 \%$ RR $\left.=0.44, \chi^{2}=5.16\right)$ was significantly decreased. The increased HLA-DQB1 alleles have a hisidine residue in common at the 30th codon for HLA-DQ $\beta$ chain. On the other hand, among the genetic markers studied by Southern blot analyses, IGLV (immunoglobulin lambda light chain, pV3.3) showed a strong association with DCM, i.e. A2/A2 genotype was found in $37.7 \%$ of patients, whereas it was observed in $18.9 \%$ of control subjects ( $\left.R R=2.6, \chi^{2}=7.77\right)$. The frequency of A2/A2 genotype was especially high in patients younger than 45 years at diagnosis (45.5\%, RR=3.6, $\chi^{2}=10.02$ ). These results imply that HLA and immunogloblin genes may be involved in the susceptibility to DCM. 


\section{32}

RELAT IONSHIP BETWEEN GENOTYPES OF CYTOCHROME P450db1 AND METABOLIC PHENOTYPES. Mari YONAHA, Ikuko KONDO(Dept. of Hum. Ecol. and Genet., Univ. of the Ryukyus, Okinawa), Masahiko WATANABE (Dept. of Neurol., Univ. of Tsukuba, Ibaraki) and Ichiro KANAZAWA(Dept. of Neurol., Tokyo Univ., Tokyo)

The relationship between genotypes associated with restriction fragment length polymorphism(RFLP) at the P450 CYP2D6 locus and the metabolic phenotypes for sparteine in heal thy Japanese was investigated. Four distinct restriction fragments of $44 \mathrm{~kb}, 29 \mathrm{~kb}, 11.5$ $\mathrm{kb}$ or $16+9 \mathrm{~kb}$ after digestion with Xba $\mathrm{I}$ were observed. The genotype of Xba I $11.5 \mathrm{~kb}$, which is predicted of the poor metabolizer( $P M)$ phenotype in Caucasians is also associated with Japanese PMs. However, one Xba I $44 \mathrm{~kb}$ haplotype in linkage disequlibrium with a Bam HI RFLP allele, designated Bam HI 2.3-, appears to be a novel mutant CYP2D6 allele in Japanese having the PM phenotype.

\section{33}

INSULIN AUTOIMMUNE SYNDROME AND A SPECIFIC HLA HAPLOTYPE CARRING DRB1*0406. Yasuko UCHIGATA, Yasue OMORI, Yukimasa HIRATA (Diabetes Ctr, Tokyo Women's Med Clg., Tokyo), Shoji KUWATA, Katsushi TOKUNAGA, Mitsuko MIYAMOTO, Takeo JUJI (Dept. Blood Transfusion, Tokyo Univ., Tokyo).

Since the first report of insulin autoimmune syndrome (IAS) was published by Hirata in 1970, most of the patients with IAS have been reported in Japan and a few cases are known in Caucasian population. IAS is the third leading cause of spontaneous hypoglycemia in Japan. Al1 the patients meet the diagnostic criteria for IAS; 1) spontaneous hypoglycenia without evidence of exogenous insulin administration, 2) a large amount of total serum immunoreactive insulin, and 3 ) the presence of anti-insulin antibody. We analyzed the nucleotide sequences of HLA class II genes by PCR. Genomic DNA from 21 IAS patients were extracted and the second exons of DRB1, DQA1, and DQB1 genes were amplified. 15 of the 21 patients had Cw4-Bw62-DR4. We designed four DR4-related SSO probes for DRB1 gene, 1 SSO probe for DQA1 gene, and 4 SSO probes for DR4-associated DQB1 gene. 100 percent of the 21 IAS patients possessed $\mathrm{DRB1} * 0406, \mathrm{DQA} 1 * 0301$, and DQB1*0302, whereas only $14 \%$ of normal Japanese controls had DRB1*0406, DQA $1 * 0301$, and $\mathrm{DQB} 1 * 0302$ ( $R R=225$, Pc $\left.<1 \times 10^{-10}\right)$. We conclude that this particular class II haplotype, DRB1*0406/DQA 1*0301/DQB1*0302, is involved in development of IAS, especially in development of insulin autoantibody. 


\title{
C 34
}

\section{HLA-DP GENE IN AORTITIS SYNDROME}

\author{
Shoji KUWATA*, Yumiko TAKEUCHI"* Katsushi TOKUNAGA*, Takeo لUلJ" \\ * Dept. Transfusion Med. \& Immunohematol., University of Tokyo, Tokyo \\ ** Second Dept. Int. Med., University of Tokyo, Tokyo
}

Aortitis syndrome has been reported to be associated with HLA-DR2 and-DQw1 in Japanese. We analyzed HLA classll genes of this syndrome. Genomic DNA was extracted from 35 patients and 51 controls. We performed RFLP study using cDNA probe for HLA-DPB1 gene. All the patients share Mspl-digested $3.4 \mathrm{~kb}$ fragment $(100 \%$ vs $80 \%$; $R R=17, p<0.05$ ). We further examined nucleotide sequences of polymorphic regions of HLA-DRB1, -DRB5, -DQB1, -DPB1 genes with the use of PCR and SSO probes. This study revealed the association between this disease and DRB1*1502DRB5*0102-DQB1*0601 (Dw12) haplotype (62\% vs $23 \%$; RR=5.6, $p<0.01$ ). As for DPB1 gene patients showed increased frequency of nucleotide sequence encoding 32 EEFVR $(89 \%$ vs $52 \% ; R R=6.4, p<0.005)$. DPB1*0901 allele was also increased in the patients, but relative risk for this allele was lower than that for ${ }^{32}$ EEFVR. DPB1*0901 allele is supposed to be in linkage disequilibrium with DRw15(DR2)-DQw6(DQw1) in Japanese. This study revealed that patients with Aortitis syndrome showed stronger association with DP gene than that with DR or DQ genes. These data suggest that HLA-DPB1 gene plays the important role in developing Aortitis syndrome.

\section{35}

\section{DOWN REGULATION OF IMMUNE RESPONSE BY AUTOREACTIVE CD8 + CYTOTOXIC T CELLS FROM A LOW RESPONDER TO STREPTOCOCCAL CELL WALL ANTIGEN.}

Hideyuki YOSHIZUMI ${ }^{1)}$, Nobuhiro KAMIKAWAJI ${ }^{1}$ ), Ko OKUMURA ${ }^{2}$ ), Yasuharu NISHIMURA $^{1 \text { ), and Takehiko SASAZUKI }}{ }^{1)}$ 1) Department of Genetics, Medical Institute of Bioregulation, Kyushu University, Fukuoka, and 2)Department of Immunology, Juntendo University Medical school, Tokyo JAPAN

We reported an HLA-linked low responsiveness to streptococcal cell wall antigen (SCW) in humans. To analyze the mechanism we established SCW specific T cell lines. During the course of generating a SCW specific $\mathrm{T}$ cell line from a low responder, autoreactive $\mathrm{CDB}^{+} \mathrm{T}$ cells were obtained which proliferated in the presence of autologous monocytes and IL-2 without the addition of SCW and had perforin, lysed autologous monocytes, an EBV-transformed B lymphoblastoid cell line (BLCL) but not autologous SCW specific $\mathrm{CD}^{+}{ }^{+} \mathrm{T}$ cell lines. This cytotoxic activity was specifically inhibited by anti-HLA class I framework monoclonal antibody, and deduced to be HLA-Bw52 and HLA-Bw54 restricted by experiments using panel cells and HLA class I-transfected BLCLs. The cytotoxicity was observed only in the presence of the supernatant of cultured perifheral blood lymphocytes.They downregulated the proliferation of SCW specific $\mathrm{CD}^{+} \mathrm{T}$ cells possibly through killing the autologous antigen presenting cell in a factor dependent manner. Our results indicate the unique immunosuppressive effect of the autoreactive $\mathrm{CD} 8^{+}$cytotoxic $\mathrm{T}$ cells recognizing self peptides in the context of HLA-B molecules on immune regulation in healthy humans. 
IDENTIFICATION OF T CELL EPITOPES IN M PROTEIN FROM TYPE 12 STREPTOCOCCUS, Nobuhiro KAMIKAWAJl, Yukari FUJITA, Kazuhiro Mori, Hideyuki YOSHIZUMI, Akinori KIMURA, Yasuharu NISHIMURA, and Takehiko SASAZUKI, (Dep., Genet., Med.,Inst., Bioreg., Kyushu Univ., Fukuoka)

Previously, we reported that low immune responsiveness to streptococcal cell wall antigenl (SCW) was inherited as dominant trait and linked to HLA. The major antigen of SCW is $M$ protein. Here, we investigated the $T$ cell epitopes in $M$ protein from type 12 streptococcus (M12). We established M12 specific $T$ cell lines restricted by HLA-DQw6(DQA1*0103, DQB1*0601), DR2 (DRB1*1502), $\mathrm{DR} 2(\mathrm{DRB} 5 * 0102), \mathrm{DR} 4(\mathrm{DRB} 1 * 0405), \mathrm{DRw} 53$ (DRB4*0101) and DPCp63 (DPA1*0201,DPB1*0901), respectively. The restriction molecule of each $T$ cell lines weré determined by $L$ cell transfectant expressing each class II molecules. We also synthesized peptides derived from M12. All M12 specific DQw6 restricted $T$ cell lines responded to the synthesized peptide derived from M12 (356-368), and other $T$ cell lines did not respond to this peptide. More than $50 \%$ of $T$ cells in M12 specific $T$ cell lines restricted by DQw6 but not other class II molecules were TCR V $\beta 5.3$ positive. Thus the peptide, M12 (356-368), may bind to $D Q w 6$ rather seleatively and activated the limitted group of $T$ cells. On the other hands, DPCp63 restricted $T$ cell line responded to $\mathrm{M} 12(112-136)$ but not $\mathrm{M} 12$ (356-368). Thus $\mathrm{M} 12(112-136)$ may bind to DPCP63 molecule rather selectively. Identification of the epitope for DR molecules were now ongoing.

ANALYSIS OF T CELL RECEPTOR RECOGNIZING STREPTOCOCCAL ANTIGEN IN THE CONTEXT OF HLA-DR4 MOLECULE. Yasuhiro OKAMOTO, Nobuhiro KAMIKAWAJI, Hideyuki YOSHIZUMI. Hiroshi HAMAJIMA, Akinori KIMURA, Yasuharu NISHIMURA, and Takehiko SASAZUKI.( Dept. Genet., Med. Inst. Bioreg., Kyushu Univ., Fukuoka )

T cell receptor ( TCR ) recognize both polymorphism of HLA and antigenic peptide bound to HLA molecule. We reported that low responsiveness to streptococcal cell wall antigen (SCW) was inherited by an HLA-linked dominant genetic trait and that $\mathrm{CD}^{+} \mathrm{T}$ cells recognizing SCW in the context of either HLA-DR4 or DQ molecule existed in low responders. Here,we generated a monoclonal antibody R1-21 specific to TCR by immunization of mice with a CD4 ${ }^{+} \mathrm{T}$ cell line HY-DR4-SCW specifically recognizing SCW in the context of HLA-DR4 molecule established from a low responder HY. Characteristics of R1-21 were as follows. 1, R1-21 reacted to 50\% of HY-DR4-SCW T cells and to $2-4 \%$ of peripheral blood lymphocytes (PBL). 2,Electrophoretic analysis of immuno-precipitates with $\mathrm{R} 1-21$ revealed $80 \mathrm{KDa}$ molecule in non-reduced condition and, 45 and $40 \mathrm{KDa}$ molecules in reduced condition. Furthermore the R1-21 bound to the molecule reactive to known anti-human TCR monoclonal antibody. 3,R1-21 stimulated a proliferative response of PBL and R1-21 positive T cells were selectively expanded in the culture. From these obsevations, it was concluded that R1-21 discriminated the heterogenity of TCR. The specificity of R1-21 is investigated by identifying TCR gene of R1-21 positive $T$ cells using reversed polymerase chain reaction,together with the characterization of R1-21 T cells in immune response to SCW. 


\section{38}

\section{HLA CLASS II GENES CONTROL SUSCEPTIBILITY AND} RESISTANCE TO RA Kuniyoshi TSUCHIYA ${ }^{1)}$, Masakazu KONDQ $^{2)}$, Akinori KIMURA $^{1}$ ), Yasuharu NISHIMURA ${ }^{1)}$ and Takehiko SASAZUKI ${ }^{1}$ ), Dept. Genet., Med. Inst. Bioreg., Kyushu University 1) Dept. Orthopedics, Fukuoka-central Natl. Hosp. ${ }^{2}$, Fukuoka, 812

Two hundred and four unrelated Japanese patients with rheumatoid arthritis(RA) were typed for HLA class II genes by using PCR-Sequence Specific Oligonucleotide(SSO) method. Frequencies of DRB 1*0405, DQA1*0301, and DQB 1*0401 were significantly increased, whereas frequencies of DRB1*0803, DQA1*0103, and DQB1*0601 were significantly decreased in patient group. These alleles are in linkage disequilibria with each other to form DRB 1*0405-DQA1*0301-DQB 1*0401 and DRB 1*0803-DQA1*0103-DQB1*0601 haplotypes respectively in the Japanese population. In DR4 group, it was observed that susceptibility to RA was decreased in proportion to the number of difference in particular amino acid residues (at 37,57,70,71,74 and 86) of DRB1 chain from DRB1*0405 which showed the highest risk for RA. DRB1*0410, which has only one amino acid difference at residue 86 from DRB $1 * 0405$, showed a weak positive association with RA. These results suggested that the amino acid residues characteristic to $D R B 1 * 0405$, especially that at 86 , were important for susceptibility to RA while DQA1*0301 and DQB1*0401 may have additional role in determinating the susceptibility. DRB1*0803 itself may control the resistance to RA because DQA1*0103-DQB 1*0601 is also in linkage disequilibrium with DRB1*1502, which was not significantly decreased in frequency. Moreover, DRB 1*0803 would control resistance to RA as a dominant genetic trait, considered from the observation that none of DRB $1 * 0803$ positive individuals was heterozygous for DRB $1 * 0405$.

C 39

Analysis of HLA class II alleles associated with Behçet's disease by the use of HLA-DNA typing: Tomiro KAWAHARADA 1),2), Akinori KIMURA 1), Rui-Ping DONG 1), Nobuhiro KAMIKAWAJI 1), Yasuharu NISHIMURA 1), Hajime INOMATA 2), and Takehiko SASAZUKI 1). (1) Dept. of Genet., Med. Inst. of Bioreg., and 2) Dept. of Ophthalmol., Kyushu Univ., Fukuoka 812, Japan)

We determined HLA class II alleles (DR, DQ, and DP) in 39 patients with Behçet's disease and 97 healthy controls by HLA-DNA typing using PCR-SSOP. It was revealed that the frequencies of the alleles of DRB1 ${ }^{*} 0802$, DQA $1^{*} 0401, \mathrm{DQB} 1{ }^{\star} 0402$, and DPB $1^{\star} 0201$ were increased in the patients with Behçet's disease (As compared with 97 healthy controls, DRB $1{ }^{*} 0802$; patients vs. controls, $25.6 \%$ vs. $9.3 \%$, relative risk $(R R)=3.4$, $\mathrm{P}<0.03 ., \mathrm{DQA} 1{ }^{*} 0401 ; 17.9 \%$ vs. $4.1 \%, \mathrm{RR}=5.4, \mathrm{P}<0.025 ., \mathrm{DQB} 1{ }^{*} 0402$; $17.9 \%$ vs. $6.2 \%, \mathrm{RR}=3.3, \mathrm{P}<0.08$., $\mathrm{DPB} 1^{\star} 0201 ; 66.7 \%$ vs. $35.1 \%, \mathrm{RR}=3.7$, $P<0.002$.). None of the increases of these class II alleles were secondary to that of HLA-B51 in the patients. All these class II alleles, except for DPB $1^{\star} 0201$, were in linkage disequilibria (L.D.). However, B51 was not in L.D. with any of these class II alleles in the controls. These results suggested that genes in L.D. with DRB1*0802-DQA1*0401-DQB1*0402 haplotype and DPB $1{ }^{*} 0201$, in addition to a gene(s) in L.D. with B51, might be involved in the development of Behçet's disease. 


\section{40}

SEQUENCE ANALYSIS OF THREE NOVEL DRw14-DRB1 ALLELES RuiPing DONG. Akinori KIMURA and Takehiko SASAZUKI (Dept. Genet., Med. Inst. Bioreg., Kyushu Univ., Fukuoka 812, Japan)

One of the charateristic features of HLA class II molecules is their extensive polymorphism in the first extracellular domain encoded by the second exon. We determined the nucleotide sequences of hypervariable second exons from three novel DRw14-related $D R B 1$ alleles (designated $D R B 1^{*} 14.6, D R B 1^{*} 14.7$ and $D R B 1^{*} 14.8$, respectively) detected by using PCR-SSOP method in Japanese and Papua New Guineans. All of the three novel alleles showed serological DRw14 specificity. The hybridization pattern of $D R B 1^{*} 14.6$ was identical to that of $D R B 1^{*} 1402$, except around codon 86 , whereas those of $D R B 1^{*} 14.7$ and $D R B 1^{*} 14.8$ were identical to that of $D R B 1 * 1401$, except around the codon 86 and 57 , respectively. Several independent clones obtained from two independent PCRs, were sequenced by the dideoxy chain termination method. Comparing the nucleotide sequences of the DRB1 second exon, two nucleotide differences (resulting in one amino acid substitution of residue $86 \mathrm{G}-\mathrm{V}$ ) were found between $D R B 1^{*} 1402$ and $D R B 1^{*} 14.6$, and one and two nucleotide differences (resulting in one amino acid substitution of residue 57 A--D and 86 V--G, respectively) between $D R B 1^{*} 1401$ and $D R B 1^{*} 14.8$, and $D R B 1^{*} 1401$ and $D R B 1^{*} 14.7$, respectively. The $D R B 1^{*} 14.6$ was closely associated with the $D R B 3^{*} 0202$ $D Q A 1 * 0501-D Q B 1^{*} 0301$ haplotype, which is associated with the $D R B 1^{*} 1402$, while both $D R B 1^{*} 14.7$ and $D R B 1^{*} 14.8$ were associated with the DRB3*0202-DQA1*0101-DQB1*0503 haplotype, as was the $D R B 1^{*} 1401$ and $D R B 1^{*} 1405$. These data suggested that a point mutation and/or a gene conversion-like event had occurred in the DRBI sublocus.

\section{41}

Recognition of Streptococcal Antigens by $T$ cells Dependent on but not Genetically Restricted by HLA classll molecules

Tohru SUDOH, Yasuharu NISHIMURA, Nobuhiro KAMIMAWAJI, and Takehiko SASAZUKI, Department of Genetics,Medical Institute of Bioregulation,Kyushu University,Fukuoka.

Superantigens cause mitogenic response of murine and human $\mathrm{T}$ cells.But they are different from mitogens in that they bind to MHC classll molecules to stimulate $T$ cells and proliferative $T$ cells have specificT cell receptor (TCR)V $\beta$ elements associated with each superantigens.And also marked diferrences exist between superantigens and classical antigens. Superantigens can activate $T$ cells in the existence of not only autologous, but also allogenic or xenogenic MHC classll molecules. And superantigens are not processed by antigen presenting cell (APC).In classical antigens recognition of T cells are strictly restricted by autologous $\mathrm{MHC}$ molecules and antigens are ordinary processed by APC.We found that Streptococcal antigens derived from limited digestion of type M6 and M12 Streptococcus pyogenes by pepsin (pepM6,pepM12) stimulated proliferation of both murine and human $T$ cells as a superantigen and that they have strong affinity to human HLA classll compared with murine MHC classll. 
C 42

POLYMORPHISM IN NONCODING REGION OF HLA CLASS II LOCUS AND ITS RELATION TO DR-DQ HAPLOTYPE

Akinori KIMURA and Takehiko SASAZUKI (Department of Genetics, Medical Institute of Bioregulation, Kyushu University, Fukuoka)

Polymorphisms in the $5^{\prime}$ flanking region of HLA-DQA1 (QAP; -262 to +20 ), the cytoplasmic exon of DRA, and the region equivalent to second exon of DRBX (pseudogene) and DQB2 (pseudogene) were investigated in addition to that in the second exons of DRB1, DRB3, DRB4, DRB5, DQA1 and DQB1. Nine alleles for QAP, two alleles for DRA, three alleles for DRBX and three alleles for DQB2 were newly identified. PCR-SSOP analyses in the Asian populations as well as 79 HTCs from various ethnic groups have revealed interesting features of linkage disequilibria between DRA, QAP, DRB1, DRBX, DQA1, and DQB1, e.g. QAP alleles linked to the DQA $1 * 0101-\mathrm{DQB} 1 * 0501$ haplotype were different from each other depending on the associated DRB1 alleles, DRB $1 * 0101$ and DRB1*0102 (DRA02, QAP1.1, DRBX1.1), DRB1*1502 (DRA01, QAP1.2, DRBX2.1) and DRB1*1001 (DRA02, QAP1.3, DRBX1.1). Another example was that the QAP1.2 was exclusively associated with HLA-DR2-DQw1 haplotypes (14 DRA-DRB1-DRB5-DQA1-DQB1 haplotypes were found) irrespective of polymorphisms in the associated DRA, DRB1, DRB5, DQA1 (DQA1*0101, DQA1*0102, and DQA1*0103), DQB1 and DQB2 genes. These observations suggested that the noncoding regions or nonfunctional genes were more conserved than the functional genes in HLA locus.

\section{43}

\section{DIRECT SEQUENCING OF C4B5 AND C4B2 ALLELES CARRIED BY CHARACTERISTIC MHC HAPLOTYPES \\ Jee Won MOK ${ }^{*},{ }^{* *}$, Katsushi IOKUNAGA*, Shoji KUWATA*, Takeo JUJI", Kyung Sook PARK $^{* *}$ \\ * Dept. Transfusion Med. \& Immunohematol., Univ. of Tokyo, Tokyo \\ ** Dept. Biol., Shungshin Womens Univ., Seoul, Korea}

Two complement $\mathrm{C} 4$ alleles, $\mathrm{C} 4 \mathrm{~B} 5$ and $\mathrm{C} 4 \mathrm{~B} 2$, which are involved in characteristic $\mathrm{MHC}$ haplotypes in Japanese, HLA-A24-Cw1-Bw54-C2C-BFS-C4A3-C4B5-DR4.1-DQw4 and HLA-A2-Cw11-Bw46-C2C-BFS-C4A4-C4B2-DRw8-DQw6, were analyzed by a direct sequencing in combination with a locus specific PCR amplification. Genomic DNA was obtained from homozygous individuals for these haplotypes. We designed three sets of primers for C4B specific amplification, which include 3 exons and introns covering about $900 \mathrm{bp}$. These exons encode a part of the $C 4 d$ region of the $\alpha$ chain. The specificity of amplifications with the primers was confirmed using DNA from C4AQO and C4BQ0 homozygotes. After the specific amplifications, the PCR products were subjected to a direct sequencing by Dye Deoxy Terminator method with use of an automatic sequencer (373A, Applied Biosystems).

As compared with the published sequence of $\mathrm{C} 4 \mathrm{~B} 1$, we found a nucleotide substitution in exon 28 of both C4B2 and C4B5 alleles (AAC $\rightarrow$ AGC; amino acid ${ }^{1157}$ Asn $\rightarrow$ Ser in proC4). A few nucleotide substitution were also detected in the introns. 


\section{44}

DUPLICATION AND DELETION OF C4 GENES ON THE JAPANESE MHC HAPLOTYPES Yoshihisa WATANABE ${ }^{1}$, Takao KOHSAKA ${ }^{1}$, Noboru KOBAYASHI ${ }^{2}$, Katsushi TOKUNAGA ${ }^{3}$, Takeo JUJI $^{3}$ (' ${ }^{1}$ Dept. Immunol., Nat. Child. Med. Res. Ctr., Tokyo, ${ }^{2}$ Nat. Child. Hosp., Tokyo, ${ }^{3}$ Dept. Transfus. Med. Immunohematol., Univ. of Tokyo, Tokyo)

The gene organization of the MHC classIII region in the two characteristic Japanese haplotypes were studied. A MHC haplotype, HLA-A24, Cw7,B7,C2C,BfS,C4A3+3,C4B1,DR1,DQw5, is one of the commonly observed haplotypes in Japanese (average 5.3\%) and shown to have two C4A and one C4B based on the C4 allotyping. Using pulsed-field gel electrophoresis, about 50-75kb duplication, including $\mathrm{C} 4 \mathrm{~A}$ and $210 \mathrm{HA}$ genes, was detected. The band intensity was measured with Bio-imaging Analyzer, and it was revealed that the 24-7-1 band was two times intense than those of other haplotypes which had two sets of $\mathrm{C} 4 / 210 \mathrm{H}$ genes. It seems that the haplotype has four $\mathrm{C} 4$ and $210 \mathrm{H}$ genes rather than three, and one of the $\mathrm{C} 4$ genes may be a pseudogene (Q0 gene). Another MHC haplotype, HLA-A24,C blank,Bw52,C2C,BfS, C4A3+2,C4BQ0, DRw15,DQw6 (average 10.0\%), was analyzed by the PCR-SS0 and PCR-RFLP method to detect the sequence differences between $\mathrm{C} 4 \mathrm{~A}$ and $\mathrm{C} 4 \mathrm{~B}$ or between $\mathrm{Ch} / \mathrm{Rg}$ antigen determinants. It is confirmed that the haplotype has no C4B-specific sequences and carries two C4A genes, one of which may be located in the $C 4 B$ locus. To clarify the mechanism of the duplication, more detailed molecular analysis must be performed. 